\title{
Pratos e mais pratos: louças domésticas, divisões culturais e limites sociais no Rio de Janeiro, século XIX*
}

Tania Andrade Lima

Departamento de Antropologia, Museu Nacional/

Universidade Federal do Rio de Janeiro

Introdução

Escavações arqueológicas conduzidas em sítios históricos do século XIX têm seguramente nos fragmentos de louças os principais vestígios recuperados. Na sua quase totalidade, esses cacos correspondem a peças diversas de serviços de jantar, chá e café, como pratos (rasos, fundos, sobremesa), xícaras, pires, malgas, canecas, tigelas, terrinas, travessas, bules, açucareiros, e assim por diante, em uma ampla variedade de padrões decorativos.

Esta freqüência impressionante de centenas ou, não raro, milhares de fragmentos requer uma reflexão sobre os possiveis significados desses artefatos para a sociedade que os incorporou com tanta intensidade à sua vida cotidiana. O considerável investimento na quantidade e na diversidade dessas louças domésticas permite supor que elas cumpriam, à época, uma função social de tal forma relevante, que o fenômeno merece uma investigação em maior profundidade. Como ressaltou Deetz, as louças devem ser compreendidas não apenas em seu papel funcional, mas também simbólico (Deetz 1977: 50).

$\mathrm{Na}$ literatura especializada norte-americana dos anos 80 , elas foram intensamente estudadas como indicadores de status sócio-econômico, acompanhando a onda de estudos sobre o assunto. Entretanto, considerando-as como um dos elementos de um complexo sistema, cuja estrutura subjacente é potencialmente observável e atingível por meio da leitura da cultura material, pode-se ir mais além. 
Entendendo-as como metáforas, através das quais as pessoas falam sobre relações sociais, é preciso compreender o que está por detrás dessa linguagem (Yentsch 1991a: 192). Ao selecionarem e se apropriarem desses artefatos, desses textos, os indivíduos os decodificam, ao mesmo tempo em que ajudam a produzitos, no ato da sua apropriação. Assim sendo, esses objetos não apenas refletem aspectos da cultura, mas são ativamente manipulados no sentido da sua construção, muitas vezes condicionando e controlando a ação social.

Esta investigação do papel social das louças e de toda a dinâmica que envolveu sua utilização pela sociedade carioca no século passado foi dirigida no sentido de se tentar compreender, a partir da cultura material, a emergência de um modo de vida burguês no Rio de Janeiro, antecedendo a instalação da burguesia propriamente dita no país, uma das peculiaridades da nossa formação social Queirós 1978: 56-7). No caso, entendemos por modo de vida burguês as formas de comportamento decorrentes da ideologia de privatização que se consolidou na Europa ao longo do século XIX, paralelamente aos avanços da industrialização, valorizando o individualismo, as fronteiras entre o público e o privado, o universo familiar e a ritualização da vida cotidiana, a acumulação de capital (tanto real quanto simbólicol, os critérios de "respeitabilidade", a fetichização do consumo e a ascensão social (Andrade Lima 1994: 87-150).

Enquanto integrante do cenário doméstico (Goffman 1975: 29) e estreitamente vinculada ao subsistema alimentar, com o qual as mulheres sempre estiveram tradicionalmente envolvidas, a louça é em geral associada à esfera feminina. Entretanto, a divisão cultural desses objetos parece acompanhar e repetir oposições binárias básicas, essenciais, que permeiam todas as esferas da vida social, visíveis em diferentes domínios da sociedade, como a divisão por sexo (masculino/feminino) e a oposição natureza/cultura, entre outras. Desta forma, impôs-se investigar de que modo essas louças foram incorporadas ao universo social e simbólico do século passado, de que modo foram utilizadas para a imposição e manutenção de limites, reforçando princípios sociais, e de que modo constituiram uma expressão da ordem então vigente no país.

Diferenciação social e sistemas de objetos no século XIX

"A aristocracia da nobreza teria esmagado os financistas sob o peso dos títulos e brasōes, se estes não the tivessem oposto uma mesa suntuosa e seus cofres-fortes. Os cozinheiros combatiam os genealogistas; e, embora os duques não esperassem deixar o recinto para zombar dos seus anfirriōes, o fato é que finham vindo, e sua presença atestava sua derrota".

Brillat-Savarin, 1825 (1995: 151 ).

Ao longo do século XIX, algumas configurações que já vinham se esboçando desde o século anterior, em decorrência do processo de industrialização e das transformações econômicas, políticas e sociais dele decorrentes, foram paulatinamente se consolidando na Europa Ocidental. Profundas mudanças estruturais foram responsáveis por novas formas de comportamento, mais condizentes com os interesses da burguesia ascendente, que, ao conseguir alcançar o poder, procurava estabilizar-se por todos os meios disponiveis.

Tendo como grande modelo a aristocracia e como mola propulsora um desejo ardente de se impor perante os que detinham naturalmente - por 
nascimento e tradição - a distinção, a elegância e o requinte, a burguesia não poupou esforços para conquistar esses atributos e, através deles, seu próprio reconhecimento. A riqueza rapidamente acumulada colocou em suas mãos um instrumento poderoso - o capital - para a tão almejada ascensão, agora obtido sobretudo com o trabalho e não apenas por hereditariedade. Ciosa do espaço conquistado, essa burguesia emergente empenhou-se em garantir suas novas posições, já que o poder não era mais conferido somente pela propriedade da terra, mas também pelas atividades comerciais, manufatureiras, financeiras, administrativas, etc.

Se num primeiro momento de afirmação os burgueses repudiaram a nobreza com todas as suas forças, tomaram-na em seguida como seu grande modelo, buscando a legitimação através de seus símbolos. Ao procurarem se equiparar a ela e mesmo eclipsá-la, dispenderam fortunas em bens de consumo das mais diversas naturezas, sobretudo pessoais e domésticos. Em espiral ascendente, este movimento atingiu extremos de paroxismo ao exacerbar a competição entre as duas classes. Ao fausto desenfreado da sociedade cortesã do século XVIII, sobrepôs-se o esbanjamento dos novos ricos, compondo o quadro descrito por Sombart (1983: 95), de decadencia e transformação das estirpes nobres. Na tentativa de rivalizar em aparato com os burgueses endinheirados, muitas das antigas famílias deixaram-se impregnar pelos novos valores, renegando suas velhas tradições; estabeleceram alianças espúrias, contraindo pesadas dívidas, não raro resgatadas com patrimônios fundiários multi-seculares. Tradicionalmente avessa à administração financeira, tarefa burguesa por excelência; cultivando um senhorial desprezo pelo dinheiro e incapaz de promover um equilíbrio mínimo entre arrecadação e despesa, a aristocracia rapidamente sucumbiu neste embate, arruinada pelos seus competentes antagonistas a caminho da hegemonia.

Vencida, foi deslocada para o fundo da cena, mas levou consigo o refinamento, o donaire e o bom gosto que o dinheiro por si só não conseguia comprar. Aos vencedores cabia agora conquistar a legitimidade que o tempo e o sangue até então conferiam, o que só se tornou possivel através de novos padrões de reconhecimento, ou seja, de novos princípios legitimadores. Daí o apreço da burguesia pelos rigorosos padrões de moralidade e probidade, pela vida familiar, pela honradez e respeitabilidade, a preocupação com as aparências e com os símbolos de distinção, na medida em que esses valores contribuíam para a fixação de nomes de família, de marcas, potencialmente capazes de substituir os antigos tífulos de nobreza.

Nas sociedades em que a aristocracia ainda era expressiva, ela continuou ditando regras e impondo estilos, sempre avidamente copiada pela burguesia. No entanto, assumir o perfil de uma classe diferente daquela a que se pertencia por nascimento e criação, implicava necessariamente o funcionamento do habitus (Bourdieu 1983: 82) em condições diferentes daquelas onde ele havia sido produzido. Ou seja, significava a burguesia deixar para trás os gostos próprios da sua classe e adotar os de uma outra, utilizando mecanismos como a imitação e a simulação, para deste modo erodir as diferenças entre ambas.

Tal apagamento, entretanto, não era desejado pelo topo da sociedade, que continuou desenvolvendo estratégias para manter a diferenciação inter e intraclasses, quer dizer, entre classes distintas e entre setores distintos no âmbito de 
1. A percepção desse mecanismo incessante que envolve dois princípios conflitantes e mu tuamente provocadores - o da imitação e o da diferenciação - atuando como forças motoras para a inovação, foi transformada em teoria por Georg Simmel no início do século, em 1904. Por muito tempo a trickle down theory foi aceita como a melhor explanação para o fenômeno da moda. Mais recentemente, entretanto sobretudo nas décadas de 60 e 70 , face à fragilidade da sua aplicação. à época atual, começou a ser fortemente criticada (ver McCracken 1988: 93-103). Para Bourdieu (1979: 275), há um erro que lhe é inerente, $o$ de reduzir a uma busca intencional (da diferenciação), o que é um efeito objetivo e automático (da imitação). Seu alto poder de previsibilidade, no entanto, permanece imbatível, razão pela qual alguns pesquisadores, como McCracken, de fendem a sua revisão, para que através de alguns ajustes teóricos ela possa ser reabilitada, atualizando-se. cada classe. Nesse sentido, "a moda emergiu como um meio de continuar as formas de discriminação social, previamente reguladas pelas regras de suntuosidade" (Miller 1987: 136). Assim sendo, as classes ociosas, com a tradição e legitimidade necessárias para ditar os padrões de gosto, continuaram controlando ferreamente os limites entre essas categorias.

Se antes a intensidade do luxo e do esbanjamento conferia tonalidades e matizes às camadas superiores, a emergência dos novos ricos e seu incomensurável poder aquisitivo passou a forçar constantes mudanças nas estratégias de diferenciação, as quais, não obstante centradas nos sistemas de objetos, incorporavam também formas sutis de comportamento no ato da sua apropriação e utilização.

Poderosos instrumentos de ação social, refletindo e influenciando relações sociais, comunicando simbolicamente identidades, hierarquia e poder, esses objetos e sua respectiva manipulação compunham um código dominado apenas por uns poucos eleitos. Ao serem apropriados e em conseqüência vulgarizados, automaticamente se desqualificavam enquanto elementos diferenciadores, o que resultava na elaboração de um novo código, vale dizer, de uma nova moda, capaz de manter as necessárias distâncias. Novas barreiras protetoras contra possíveis intrusos criavam-se assim à volta desse círculo de bem-nascidos, distinguindo-os dos demais e delimitando um plano praticamente inacessivel aos de fora". Como reconheceu Baudrillard, "o acesso de camadas mais numerosas a esta ou aquela categoria de signos obriga(val as classes superiores a distanciar-se por meio de outros signos em número restrito" (Baudrillard 1991: 1161 .

Não apenas a aristocracia desejava marcar bem o seu distanciamento dos burgueses endinheirados, como estes, por sua vez, nas suas tentativas de aproximação dos segmentos ociosos, empenhavam-se em se afastar do universo do trabalho no qual forjaram e acumularam suas fortunas, de modo a viabilizar a sua absorção pelos aristocratas. Isto fazia com que a cultura material fosse ativamente manipulada para marcar as distâncias sociais entre todas essas categorias, num processo que se apoiou fortemente no sistema de objetos e no comportamento inerente à sua utilização, de tal maneira que este sistema está inequivocamente relacionado à hierarquia social.

A diferentes posiç̃es no espaço social correspondem diferentes escolhas estéticas e estilos de vida distintos. Tais escolhas, feitas com base no habitus de classe, marcam claramente essas posições, impondo distâncias. Os bens e os modos pelos quais eles são consumidos atuam como marcas simbólicas de distinção, apontando quem é quem. Por meio delas, "os sujeitos sociais se exprimem e do mesmo tempo constituem para si mesmos e para os outros sua posição na estrutura social" (Bourdieu 1974: 14).

O gosto, aqui entendido como "a propensão e aptidão à apropriação (material e/ou simbólica) de uma determinada categoria de objetos ou práticas" (Bourdieu 1983: 82), passou a comandar o espetáculo, diferenciando uma categoria da outra. Não era mais apenas a propriedade dos meios de produção que determinava a dominação, mas também o gosto socialmente reconhecido, como a capacidade de determinar termos de distinção (Featherstone et al. 1991: $66)$. 
Cuidadosamente cultivado por meio de um lento processo educativo, esse gosto não podia deixar transparecer o quanto havia custado a sua interiorização. $\bigcirc$ esforço e o investimento que levavam a esse resultado não podiam ser visiveis, reconhecíveis, sob pena do seu próprio esvaziamento. Devia ser exteriorizado como uma qualidade inata, uma inclinação, uma tendência inerente ao seu portador. Atributo absolutamente "natural" - um dom como a graça, a espirituosidade, a inteligência - a elegância nas escolhas, atitudes e gestos devia parecer uma segunda natureza, que se manifestava em todos os setores da vida social e cotidiana, incluindo-se aí os modos de comer e beber, falar, se mover, etc.

Desta forma, a espontaneidade, o relaxamento, o charme e a simplicidade nas maneiras dos bem-nascidos, que decidiam o que e como ia ser usado pela sociedade, eram a grande aspiração dos ascendentes - alguns de origens muitas vezes duvidosas - que, ao tentar copiá-los para assegurar sua escalada social, obtinham um resultado muitas vezes afetado, pretensioso, grotesco mesmo, não raro beirando o ridículo. O conflito entre o gosto de classe, de inclinação, e o gosto de vontade resultava em confusas misturas que denunciavam, com maior evidência ainda, a pretensão dos arrivistas.

Como assinalou Bourdieu, "grupos de status se definem menos por um ter do que por um ser, irredutivel a seu ter, menos pela posse pura e simples de bens do que por uma certa maneira de usar estes bens, pois a busca da distinção pode introduzir uma forma inimitável de raridade, a raridade da arte de bem consumir, capaz de tornar raro o bem de consumo mais trivial" (Bourdieu 1974: 15).

Compartimentação e função social do espaço doméstico

A casa, entendida como o local destinado ao abrigo, ao repouso, ao convivio, à alimentação, enfim, à safisfação de necessidades básicas dos indivíduos (Laslett 1972 apud Beaudry 1984: 30), é um espaço construído e, enquanto tal, ordena o meio físico, fornece o suporte para o desempenho dessas rotinas e cria condições para a interação dos seus ocupantes. Estes, em geral unidos por laços de parentesco ou vínculos de outras naturezas lagregados, hóspedes, empregados, etc.l, partilham essas atividades cotidianas, compondo um grupo residente, onde cada um dos seus membros desempenha papéis e tarefas diferenciadas (ver Bailey 1990: 22-4; Beaudry 1994: 30-1; Bender 1967; Westman 19911.

Esta distribuição obedece às divisões básicas da sociedade em categorias de gênero (masculino/feminino), faixas etárias (crianças/adultos, jovens/velhos), e em hierarquias que acompanham a estrutura social, de tal modo que uma unidade doméstica constitui o que se designa como "átomo básico da sociedade", em termos de produção, reprodução, consumo e socialização (Mrozowski 1984: 31; Perrot 1987: 105).

A casa, bem como fudo o que se encontra em seu interior, integra um sistema de comunicação não verbal, funcionando como veículo por meio do qual estruturas sociais e categorias culturais adquirem existência sensorial (Blanton 1994: 7-9; ver também Duncan 19851. Enquanto componente de um sistema social muito mais amplo, está necessariamente vinculada a complexas redes de relações 
2. Para uma contestação dessa teoria de privatização da esfera doméstica, ver Crow \& Allan (1990). e, conseqüentemente, submetida às tensões e pressões que atuam sobre esse sistema como um todo. Desta forma ela reproduz, microcosmica e internamente, o que se passa neste universo mais abrangente, constituindo um objeto de investigação bastante pertinente para a análise de processos sócios-culturais.

As forças geradoras dessas tensões e pressões produzem alterações, ou mesmo transformações no espaço edificado que resultam em padrões morfológicos passiveis de serem percebidos, reconhecidos e interpretados. Esta morfologia obedece a "princípios taxonômicos", peculiares ao sistema cultural que os adota, e que uma vez aplicados são continuamente incutidos nos seus ocupantes, os quais por sua vez os reforçam e realimentam (Bourdieu apud Blanton 1994: 10; Robben 1989: 5711.

As diferentes configurações que as unidades domésticas assumiram através do tempo e no espaço são sem dúvida produtos de normas culturais, mas também de escolhas, de decisões individuais, resultando portanto não só de processos internos, ou seja, de relações de poder na esfera doméstica, mas também de processos externos, na medida em que essas relações reproduzem a dinâmica social mais ampla.

Com o progressivo fortalecimento da burguesia foi intensificada a concepção de público e, por conseguinte, do seu correlato, o privado. Os novos valores, ao adotarem o pudor, a reserva, e, em consegüência, a defesa cerrada da intimidade, foram incorporados à arquitetura, influenciando fortemente a compartimentação dos espaços domésticos. Funções antes comunitárias, exercidas publica e coletivamente, individualizaram-se, passaram para domínios reservados, privatizando-se e requerendo ambientações adequadas ${ }^{2}$.

Em sua trajetória ascendente, a burguesia tomou a família, e por extensão a casa, como fundamento da nova ordem. Os papéis sociais, ao se tornarem mais especializados, exigiram novas disposições espaciais, determinando profundas alterações na repartição da unidade doméstica, que mudov em tamanho, estrutura e função. Diante de novos programas de necessidades, os cômodos, antes unidos entre si de tal forma que para se atingir um aposento era necessário passar por dentro de outro, separaram-se para atender ao crescente individualismo. Surgiram espaços de distribuição e circulação antes inexistentes, intensificando hierarquias de classe e gênero (Roberts 1991), como vestíbulos, halls, saguões, antecâmaras e sobretudo corredores - simultaneamente unindo e isolando os compartimentos, garantindo-hes total privacidade-bem como escadas, funcionando como corredores verticais (ver Friedlander 1990; Lawrence 1990; Samson 1990).

Barreiras reais ou simbólicas foram erguidas, reforçando limites sociais e legais (Harrington 1989; Korosec-Serfaty 1985: 73), liberando ou controlando acessos, restringindo as possibilidades de circulação e separando áreas públicas de áreas privadas: algumas bem concretas, como portões, cercas, muros, sebes, jardins, pórticos; outras mais sutis, como a interdição de ultrapassar a entrada da residência sem ser convidado (cf. Guerrand 1987: 332), adentrar corredores, passar do piso inferior para o superior ou extrapolar os limites dos espaços destinados aos visitantes.

Novos cômodos foram criados para atender a funções específicas, como escritórios, gabinetes, bibliotecas, salas de jogos, de fumar, costurar, engomar e principalmente de jantar. Os filhos passaram para aposentos próprios, separados 
dos pais, surgindo os quartos de crianças. Outros foram deslocados - como as áreas de processamento de alimentos e de trabalho doméstico em geral - para os fundos das casas, longe do olhar dos estranhos, assegurando-se, com essas alterações, o isolamento acústico e visual da esfera agora considerada privada. Portas e janelas funcionavam do mesmo modo como barreiras, viabilizando ou impedindo, conforme a circunstância, a ligação interior/exterior e vice-versa (Clark 1988).

A região de fachada e de elementos externos, como portões, jardins, caminhos, etc., transmitia mensagens diretas, explícitas, comunicando a identidade social dos residentes. A parte dianteira da casa - sala de visitas, sala de jantar, escritório, sala de fumantes, etc. - tornou-se o espaço de sociabilidade por excelência, através do qual o grupo residente se relacionava com o exterior. Formal, destinado ao entretenimento, ao lazer, e, por conseguinte, à representação social, tinha seu acesso permitido aos de fora. Palco para a exibição das posses e boas maneiras dos seus moradores, era por meio dele que os indivíduos negociavam suas posições na estrutura de classe.

Nas áreas intermediárias e nos'fundos ficavam as salas íntimas, quartos, cozinhas, etc., domínios do comportamento informal, reservados ao repouso, à intimidade familiar, às atividades biológicas - como dormir, procriar, comer, excretar - à higiene corporal e aos serviços domésticos. Com circulação permitida apenas aos membros do grupo residente e aos parentes muito próximos, eram rigorosamente interditados aos estranhos. Não raro a sala de jantar era implantada em áreas intermediárias, funcionando como zona limítrofe entre o público e o privado.

O mapeamento desses diferentes "territórios" da casa, suas respectivas funções e implantações no espaço deixa entrever dicotomias fortemente simbólicas (alto/baixo, frente/fundos, exterior/interior, claro/escuro), que estão inequivocamente articuladas à estrutura da sociedade que os concebeu $e$ materializou (Bourdieu 1973). Toda esła compartimentação expressa códigos binários que regiam seu universo e, por extensão, os papéis e tarefas rigidamente polarizados daqueles que por ele transitavam, de tal forma que os domínios masculinos da esfera doméstica podiam ser definidos como públicos, dominantes, ativos, visíveis, centrais, permitidos, ordenados, claros, asseados, requintados, diretamente ligados ao exterior e de livre acesso. Já os femininos eram eminentemente íntimos, privados, interiorizados, passivos, subjugados, de baixa visibilidade quando não ocultos, periféricos, despojados, sujos, escuros, em desordem, de acesso restrito ou proibido aos de fora.

Essa nova repartição, altamente simbólica (Davidoff 1990: 242), reforçou as relações de poder intra e intergrupais. $O$ ambiente passou a ser mais controlado, o comportamento mais codificado, as relações sociais mais formais (Clark 1988: 544). Com essa reformulação do espaço doméstico e a adoção de um novo conceito de moradia, a casa tornou-se um instrumento não apenas para demarcar papéis sociais, mas sobretudo para assegurar e fortalecer redes de alianças em vários níveis. Nesse contexto, a sala de jantar assumiu um papel fundamental. 
3.A respeito, cf. Graham (1992: 48) e Arquivo Judiciário da cidade do Rio de Janeiro).
Salas de jantar, palcos da representação social

Nos séculos anteriores, comia-se nas proximidades do fogo, onde o alimento era preparado, em cômodos multifuncionais. Este atuou sempre, desde tempos imemoriais, como um elemento agregador, à volta do qual as pessoas se juntavam para se aquecer, processar alimentos, se alimentar ou em busca de iluminação durante a noite. Por extensão, esta tornou-se a ocasião oportuna para outras formas de partilha, vale dizer, de idéias, experiências, informações, etc., para a socialização, enfim.

As primitivas fogueiras transformaram-se progressivamente, com o passar dos tempos, em lareiras (nos países frios) ou fogões a lenha, mantendo no entanto a mesma capacidade de reunir os indivíduos à sua volta, para as mesmas finalidades. Indissociado da idéia de lar-etimologicamente "lugar onde se acende o fogo" - onde se encontra abrigo, calor e alimento, o lume tornou-se o centro da unidade doméstica, ponto vital com forte conteúdo simbólico, implantado em um espaço comunitário no qual se reunia o grupo familiar e residente. A identificação era de tal ordem que em Portugal e no Brasil Colonial as palavras fogo e fogão eram sinônimos de moradia.

O século XIX, entretanto, veio confirmar uma tendência já esboçada no século anterior, no sentido de separar o local de preparo de alimentos do local de consumo. A superposição das áreas de serviços e de estar passou a ser considerada inconveniente e inadequada. A mesa de comer ganhou um ambiente próprio, que the foi exclusivamente destinado - a sala de jantar - transformada em cômodo imprescindivel na casa burguesa.

Em geral pesada, sólida, em madeira de lei, muito bem polida, a mobília de jantar passou a simbolizar fortemente o grupo familiar e os valores que deveriam cimentar seus membros: ordem, união, harmonia, coesão, expressos nas cadeiras perfeitamente alinhadas à volta da mesa; respeito, apreço pela hierarquia, nos lugares especialmente reservados aos mais proeminentes, assim como pelo patrimônio familiar, nas pratas, cristais e porcelanas ostensivamente exibidos à sua volta. Todos os demais elementos do seu mobiliário estavam diretamente relacionados à alimentação, funcionalmente destinados à guarda, exposição ou apoio dos objetos utilizados no decorrer das refeições, como aparadores, étagères, consoles, buffets, credências, cristaleiras, guarda-louças, etc. Essas peças eram constantemente arroladas nos inventários da segunda metade do século, mostrando a importância que assumiu a exibição das louças de familia ${ }^{3}$. Da mesma maneira os adornos que the eram incorporados (quadros, papéis de parede, pinturas murais, enfeites de mesa, etc.) sugeriam direta ou indiretamente o universo dos alimentos (temática de frutas, cenas de caça, naturezas mortas, etc.), deixando bem clara a medida da especialização desse aposento.

O século XIX fez da sala de jantar um espaço de exibição, de representação, eminentemente masculino, onde eram expostas as alfaias da família, símbolos de prestígio e superioridade social. O senhor da casa comandava esse espetáculo, destinado sobretudo à consolidação de vínculos e alianças.

Por outro lado, o processamento da comida tornou-se uma tarefa especializada da mulher e o lugar do fogo - a cozinha - um cômodo também especializado, exclusivamente feminino. Separado dos demais aposentos, 
segregado, banido para as áreas mais recônditas da casa, como fundos, subsolos e porões, foi transformado em espaço de rejeição. Em geral muito sujo, fumarento e malcheiroso, fazia um contraponto à sala de jantar: em lugar das finas alfaias, grosseiras louças de barro, pesadas panelas de ferro e alguidares de madeira que, ao lado dos vegetais e animais aí processados compunham um ambiente muito mais próximo da natureza que a refinada sala de jantar, recendendo cultura e civilização. Este era o domínio da senhora, dona-da-casa e dos criados, a quem só era dado atuar com desenvoltura nos bastidores da cena doméstica. Também fortemente simbólico, telúrico e uterino, este cômodo era a fonte de alimento da unidade doméstica, gerador de energia, onde a figura materna - efetiva ou substituta - cumpria a sua função biológica e cultural de nutrị o núcleo familiar.

Um espaço intermediário entre ambos - e de certa forma ambíguo, quando existente - era a sala de jantar íntima ou sala de almoço, onde se reunia a família no seu cotidiano e à qual os estranhos não tinham acesso. Nele, ao invés de se privilegiar a exteriorização dos sinais de riqueza, procurava-se incutir nos membros do grupo sentimentos de união, lealdade, fraternidade, partilha e de estímulo ao convivio afetivo no recesso e intimidade do lar (ver Martin-Fugier 19911. O equipamento aí utilizado era igualmente ambíguo, um meio termo entre - aparato da sala de jantar formal e a rusticidade da cozinha. Na ausência desse cômodo íntimo, a maior ou menor informalidade era determinada, na grande sala de jantar, pela presença ou ausência de pessoas de fora, o que implicava diferenças no protocolo, na decoração e nos objetos utilizados à mesa, assim como na estrutura da refeição, na qualidade e quantidade dos alimentos e bebidas servidos.

A criação de um cômodo especialmente dedicado às refeições na casa burguesa mostra bem a dimensão e o significado que elas assumiram na nova ordem, reforçada ainda pelo mobiliário exclusivo e por todo um elenco de objetos destinados ao consumo alimentar, agora pensados, concebidos e produzidos em uma outra perspectiva.

Regras e mais regras: o comportamento à mesa

"Toutes ces choses ne sont que de puerilités, il est vrai, mais de combien de puerilités notre existence se composetelle, à tout bien considérer ?"

Le Savoir Vivre, 1877

A necessidade que um organismo tem de ingerir continuamente alimentos para se manter em condições saudáveis fez da alimentação um dos domínios mais propícios à ritualização, tão cara ao universo burguês. Seu caráter cíclico, repetitivo, favoreceu sua apropriação para o estabelecimento de rituais diários, pelos segmentos desejosos de ordenar e balizar as relações sociais em seus diferentes níveis. Para isso, não apenas eles reforçaram antigos comportamentos, como também introduziram novas regras em seus procedimentos de rotina, de modo a assegurar, com esse desempenho, tanto reafirmações quanto renovações e transformações.

Em virtude da ingestão de alimentos ter que ser feita a intervalos regulares, relativamente breves, a ritualização de todas as refeições seria um ônus insuportável para o grupo social, o que explica a escolha de apenas uma delas como alvo de práticas mais elaboradas. Por se tratar da refeição feita ao término 
da jornada de trabalho, propícia ao convívio social, ao relaxamento, à diversão, coube ao jantar o investimento maior, transformado no principal repasto do dia. Já - almoço, feito em meio à faina diária, era uma refeição em geral abreviada, informal, com uma estrutura mais simples, de caráter íntimo, não raro composta por alimentos frios.

Brillat-Savarin assim descreveu este processo nas primeiras décadas do século XIX: "um espírito geral de convívio se expandiu em todas as classes da sociedade; as reuniões se multiplicaram, e cada um, ao regalar seus amigos, procurou oferecer-thes o que tinha de melhor nas esferas superiores. Em conseqüência do prazer da boa companhia adotou-se em relação ao tempo uma divisão mais cômoda, os afazeres ocupando o período que vai do começo ao fim do dia, e à noite sendo reservados os prazeres que acompanham e seguem os festins" (Brillat-Savarin 1995: 277).

Dar um jantar passou a ser considerado o mais importante dos deveres sociais, um complicado ritual regido por centenas de pequenas e quase imperceptíveis regras, que compunham um rígido protocolo. Em resposta à complexificação crescente deste cerimonial, formulada pelas camadas mais altas à guisa de diferenciação, multiplicaram-se os manuais de comportamento, avidamente consumidos pelas camadas médias. Códigos de boas maneiras foram sucessivamente editados e reeditados ao longo de todo o século XIX, para que essas normas pudessem ser absorvidas em toda a'sua extensão pelos ascendentes que aspiravam ocupar um lugar no topo da hierarquia social, ou seja, por todos aqueles que não as tinham apreendido naturalmente, desde o berço, na medida em que essas atitudes não faziam parte do seu cotidiano. Em 1872, o Modern etiquette in private and public expressou abertamente: "This book is written for those who do not profess to know much of sociely" (Anon 1995: 277).

Deste modo o jantar tornou-se uma cerimônia e a sala de jantar um espaço sagrado, no qual a celebração constante de ritos de comunhão, de partilha, assegurava a necessária coesão familiar, estabelecia tramas de reciprocidade, selava alianças e negociava as ambicionadas posições na hierarquia social.

Por ter passado a constituir uma ação ordenada, com princípio, meio e fim, sistematicamente repetida, com suficientes estímulos sensoriais passíveis de serem manipulados simbolicamente e com uma dimensão coletiva que the conferia significado social, emitindo mensagens, o jantar incorporou as principais propriedades que os rituais devem possuir (Moore \& Myerhoff apud Wall 1994: 1111.

Poderosos meios de comunicação, os rituais atuam como marcadores e indicadores de posições sociais, reforçam a estrutura de uma sociedade e sua ordenação do mundo (Saile 1985: 95). Nesse sentido as refeições foram intensamente manipuladas para comunicar todos esses aspectos e ao mesmo tempo assegurar, por meio do cenário onde elas se desenrolavam, da sua estrutura dramática, do domínio corporal, das seqüências de ações, gestos, discursos e sobretudo do sistema de objetos, o efetivo controle do poder, em seus diferentes niveis.

Em sua origem, este foi um processo deflagrado a partir do momento em que surgiu a interdição de comer com as mãos, em uma clara determinação da sociedade se distanciar, tanto quanto possível, do estado de natureza. Expressão 
da mais absoluta animalidade e selvageria, assim eram ingeridos os alimentos no medievo, período de pouca rigidez nas formas de controle social. Gradativamente começaram a surgir códigos de comportamento nas sociedades feudais, sugerindo normas de conduta que diferenciassem o comportamento de cortesãos dos rudes camponeses, tão próximos da natureza.

A comida, à época, ficava permanentemente disponível na unidade doméstica: um caldeirão suspenso sobre o fogo da casa, ao longo do dia, mantinha em fervura quase constante um cozido de cereais, legumes e verduras, ao qual era adicionado um pedaço de carne ou gordura animal, em geral toucinho. Não havia, portanto, um momento determinado para a comida ficar pronta, ela estava sempre pronta, à disposição dos que chegavam, a qualquer hora (Pounds 1989: 2101 .

Pães e assados complementavam essa dieła monótona. Os grandes animais abatidos eram trazidos inteiros para a mesa, trinchados e consumidos num sistema de vida comunal. Os caldos eram partilhados em uma mesma tigela, os vinhos bebidos em um mesmo cálice, já que eram raros os utensílios de mesa. A faca era de uso comum, destinada basicamente ao corte das carnes. As colheres, não obstante conhecidas desde tempos imemoriais, tendo como protótipo a própria mão humana, quer feitas de conchas, cabaças ou cascas de frutos, quer de cascos de animais, osso, marfim, etc., pouco eram usadas à mesa, na medida em que os alimentos líquidos, como sopas, caldos, etc., eram ingeridos diretamente nas tigelas. O garfo, por sua vez, surgiu tardiamente na Itália (suas primeiras referências vêm da refinada ltália renascentista, em particular de Veneza e Florença, ao final da Idade Médial, com apenas dois longos dentes, para atender à função específica de espetar e destinados a servir comida (ver Braudel 1995: 181-3). Posteriormente passou a ser feito com três dentes, que foram aos poucos encurtados e estreitados até assumir a forma atual, com quatro dentes, e a função de introduzir o alimento na boca (Visser 1992: 189 e 192).

De acordo com Norbert Elias (1990), os manuais de civilidade à época recomendavam não babar à mesa, não escarrar, não oferecer ao outro o que já havia sido mastigado, não colocar na travessa restos de alimentos parcialmente consumidos, não limpar os dentes com a faca ou com a toalha, não enxugar o suor ou assoar o nariz com o guardanapo, não roer ossos como cães, não bufar repugnantemente como focas, sendo freqüentes as analogias com animais em geral, ou mais específicos, como porcos, lobos, etc.: Esses comportamentos animalescos começaram a ser evitados e vigorosamente combatidos, numa clara tentativa de apartação do estado de natureza.

No século XVI, ao se esboçar com as monarquias absolutas uma nova aristocracia e uma hierarquia social mais rígida, foi aumentando o rigor em relação às condutas, que se tornaram pouco a pouco mais refinadas à mesa. Ainda segundo Elias, no início desse período os poucos talheres existentes ainda eram coletivos. Grandes guardanapos, do tamanho de toalhas, eram usados no ombro esquerdo e no braço. Não havia pratos individuais e a comida sólida era colocada sobre grandes rodelas de pão, à guisa de suportes. Ao utilizarem as mãos para pegar os alimentos, as pessoas deviam usar apenas três dedos, o que funcionava como sinal de diferenciação social, sem jamais lambê-los ou enxugátos nas roupas.

No século seguinte, começaram a surgir os pratos individuais, feitos 
sobretudo de madeira e de metais como o estanho e a prata, com as classes dominantes se iniciando na prática de comer com seus próprios garfos e colheres. Os imensos guardanapos eram destinados agora a cobrir toda a frente do corpo, até os joelhos. Intrincadas dobraduras em forma de peixes, barcos, pirâmides, rãs, frutas, pavões, galinhas, etc. atingiram o seu apogeu em Versalhes.

A liberalidade anterior foi sendo progressivamente substituída por novas regras, ou seja, por sucessivas restriçoes. Recomendava-se que sopas, caldos, etc., fossem ingeridos em pratos fundos, com a colher, e não mais diretamente nas tigelas. Os alimentos não podiam ser soprados, os dedos jamais merguthados nos molhos, sendo considerada grosseira a escolha para si das melhores porções. Ao final do século, pratos rasos de louça já eram comuns na França, embora sua plena aceitação e disseminação só tenham vindo a ocorrer muito posteriormente, no século XIX, tendo em vista a lentidão com que se processou a absorção dessas inovações.

Gradativamente os talheres foram se fortalecendo como mediadores entre o estado de natureza e o estado de cultura. No século XVIII, as recomendaçōes dos manuais de civilidade ainda enfatizavam a não utilização das mãos - frisando que apenas os canibais comiam com os dedos - ao mesmo tempo em que criavam inúmeras limitações para o uso individual da faca. Instrumento considerado perigoso, uma arma em potencial, deveria ser utilizado apenas quando estritamente necessário.

Na natureza, o comer é um ato profundamente violento, na medida em que implica a ingestão de outras formas vivas que devem ser sacrificadas e trituradas com os dentes para assegurar a sobrevivência do seu predador. Mais ainda, pela disputa que envolve o alimento, numa competição em que os animais agridem ou se defendem na luta pela auto-preservação. Reminiscências dessa animalidade persistem no comportamento humano e a sensação da fome torna as pessoas mal-humoradas; intolerantes e agressivas. Não são raras as discussões - ou mesmo violências físicas - decorrentes de investidas sobre o alimento alheio, $e$ Visser (1992) defende a tese de que o ritual da refeição é, na verdade, uma estratégia para dissimular essa violência. A função da etiqueta seria a de atenuáta, impondo limites estritos por meio de um rígido protocolo.

As inúmeras interdições surgidas em relação ao uso da faca à mesa parecem confirmar ao menos em parte essa teoria. Arma masculina, fálica, utilizada na caça e na luta, era essencial para trinchar a carne. Numa tentativa de impedir que seu potencial de ataque se transformasse em ação efetiva, foram estabelecidas restrições ao uso individual durante as refeições, tendo se transformado no único talher que em circunstância alguma pode ser levado à boca. Sua ponta aguçada foi substituida por uma extremidade arredondada. Ao ser passada para alguém, tornou-se de praxe oferecê-la sempre pelo cabo, com a lâmina voltada para quem a entrega, de maneira a não oferecer risco para quem a recebe e ao mesmo tempo retirar qualquer conotação agressiva do gesto. Ainda de acordo com Norbert Elias, no século XVIII já estavam no mesmo patamar de grosseria jogar restos de comida no chão, colocar mãos ou cotovelos no prato, despedaçar a carne ao cortá-la, pegar sal com os dedos, levar a comida ao nariz para cheirá-la, usar a faca para levar comida à boca ou segurá-la desnecessariamente. Á mesa, o lugar do pão era à esquerda e deveria ser partido apenas com a mão, nunca com a 
faca; do outro lado, à direita, ficavam os três talheres, sendo que a colher só ganhou o seu formato atual, com cabo horizontal, nesse período. Um novo gestual foi introduzido na utilização desses implementos. Os movimentos das mãos foram suavizados, na medida em que passou a ser correto segurátos não mais com a mão fechada, como quem empunha um bastão, porém delicadamente, com os dedos entreabertos. O guardanapo, por seu lado, passou a ser usado apenas sobre os joelhos.

Os antigos modelos de refeições medievais e renascentistas evoluíram assim para uma nova composição, com um pouco mais de ordem, método, limpeza e elegância, que no século XVIII, na França, assumiu a seguinte feição: a mesa era posta de modo a transmitir a impressão de opulência e abundância, carregada de alimentos e objetos decorativos dispostos simetricamente, numa tentativa de se evitar o caos em meio a tal parafernália. Pratos, talheres, cálices, toda sorte de travessas com profusões de alimentos, jarras, garrafas de vinho, candelabros, saleiros, etc., eram dispostos à volta de centros de mesa fartamente elaborados com pirâmides de frutas. As pessoas sentavam-se muito próximas umas das outras, tinham livre acesso a todas as comidas expostas na mesa e serviam-se mutuamente ao longo da refeição. Para bem cumprir esta tarefa, fazia parte da boa educação saber quais as melhores porções dos alimentos, pois estas é que deveriam ser oferecidas aos que estavam mais perto. Os diálogos travados ao longo de um jantar, tal como reproduzidos por Brillat-Savarin (1995: 219), ilustram bem a sua dinâmica: "... Faria a gentileza de me alcançar as batatas que estão na sua frente? ... Faria a gentileza de alcançar para mim o feijão de Soissons que vejo na ponta da mesa? ... Madame, se seus olhos não me enganam, aceitaria um pedaço dessa torta de maçã? Permita-me que lha sirva". Eventualmente se recorria ao auxílio dos criados, mas a tarefa de fato competia aos convivas.

Trinchar os assados era uma prerrogativa masculina - na medida em que implicava o uso da faca - uma verdadeira arte para a qual os indivíduos eram preparados e educados, havendo inclusive professores especializados na transmissão desse tipo de conhecimento. Ponto culminante da refeição, era o grande momento para o qual convergiam todas a atenções. A distribuição das partes obedecia a uma hierarquia onde eram considerados sexo, idade e prestígio social. As mulheres jovens, por exemplo, eram servidas apenas carnes mais leves, de natureza delicada como a delas, como o peito das aves, estando as mais velhas, entretanto, liberadas para comer o que bem desejassem. As jovens senhoras deveriam evitar ainda o consumo de outros alimentos, como queijos e temperos fortes, para não comprometer a pureza de seu hálito.

A estrutura ${ }^{4}$ desse jantar à la française, que perdurou por toda a primeira metade do século XIX, consistia em pelo menos duas a três cobertas (ingl.: course, fr: servicel $)^{5}$, além da sobremesa, devendo começar por alimentos leves, seguindose os mais pesados, para terminar com outros mais leves ainda, que tivessem a propriedade de limpar o paladar. Uma maior complexidade e requinte eram conferidos à refeição através da ordenação e combinação de atributos como frio/quente, salgado/doce, úmido/seco, líquido/sólido, macio/duro, e assim por diante. A mesa era protegida por três ou mais toalhas de linho branco, colocadas umas sobre as outras e sucessivamente retiradas ao final de cada etapa, à medida que evoluía o jantar, de tal maneira que ao se iniciar uma nova
4. Entende-se aqui por estrutura de um jantar a maneira como são selecionados, ordenados e combinados os diversos pratos no âmbito de uma mesma refeição. É definida pelo número e conteúdo das cobertas, bem como pela relação entre elas.

5. O termo coberta caiu em desuso, na língua portuguesa, possivelmente como decor. rência das mudanças ocorridas na estrutura das refeições ao longo do século $\mathrm{XX}$. Os dicionários mais modernos não o incorporaram, mas os do século XIX o definem como"os pratos e iguarias (ou conjunto de viandas, ou os manjares e viandas) que se põem na mesa de cada vez" (Faria 1859; Moraes Silva 1858; d'Almeida \& Lacerda 1862; Vieira 1871; Fonseca 1881). Vieira exemplifica, mencionando "um jantar de seis cobertas". Em 1830, no entanto, este termo aparece claramente com uma segunda acepção: no "Diálogo entre um professor e seu discípulo à mesa de jantar", publicado no periódico $O$ Mentor das Brasileiras do dia 14 de maio, é dito que uma coberta ou ser viço de mesa compõe-se de um prato, de um guardanapo, de um garfo, faca, colher, um copo para vinho e outro para água", equivalente portanto ao ingl. cover (ver Allen 1915) e ao fr. couvert. 
6. Do fr. mets: cada um dos pratos que entram na ordenação de uma refeição. Originalmente, no medievo, os entremets eram entretenimentos destinados a auxiliar a digestão $e$ a divertir os convivas entre as cobertas, como danças, música, mascaradas, jogos de prestidigitação, exibições de anões, animais exóticos, bufôes, etc. Transformados posteriormente em exotismos culinários, também com fins lúdicos, tais como esculturas em manteiga ou prodígios feitos com açúcar, foram reduzidos, nos séculos XVIII e XIX, a pequenas delícias comestiveis para serem degustadas nas pausas entre as atividades do jantar. Também chamados pratos secundários ou pratos do meio. coberta, tudo estivesse limpo e em ordem.

Segundo modelo fornecido por Visser (1992: 198-9) e confirmado em Brillat-Savarin (1995: 274), a primeira coberta compreendia duas ou mais variedades de sopas, seguindo-se os chamados relevés, que podiam ser assados de carneiro, peru ou grandes peixes. Outra alternativa era se começar pelas entradas (entrées), que podiam incluir frango, vitela, costeletas, língua, vol-auvent, peixes, destinados apenas a preparar o apetite para os assados, ponto alto da refeição. Alguns entremeios (fr.: entremets, ingl.: between-courses) ${ }^{\circ}$ completavam a coberta. À volta das grandes travessas ficavam pequenos pratos satélites com os hors-d"oeuvre (literalmente "fora da obra"), ou seja, as iguarias secundárias, independentes dos principais trabalhos, como pequenas tortas, ostras, ovos, alcachofras, rabanetes, anchovas, atuns marinados, etc.

Após a remoção de todos os pratos dessa primeira coberta era retirada a toalha de cima, deixando à mostra a subseqüente, limpa, de modo a permitir o reinício dos serviços. Na segunda coberta eram servidos os grandes pratos: vários assados e as chamadas peças de resistência (pièces de résistence), acompanhadas por saladas, legumes e entremets doces, como cremes, geléias e sorvetes.

Para a última coberta todas as toalhas eram retiradas, a mesa ficava limpa, exposta na madeira nua, para que fosse exibida a sua boa qualidade. Vinham então os queijos, doces, folheados, frutas, conservas, etc., em suma, as sobremesas (ou seja, sobre a mesa, diretamente, sem toalha), que eventualmente podiam incluir também patês de carne. A essa altura eram trazidas as lavandas. Brillat-Savarin (1995: 315-6) reporta-se ao antigo costume de enxaguar a boca após a refeição, revivido como uma inovação nas primeiras décadas do século passado e por ele considerado como "inútil, indecente e desagradável". Segundo ele, "na casa que se vangloria dos mais belos costumes, domésticos distribuem aos comensais, no final da sobremesa, tigelas cheias de água fria, no meio das quais se encontra um copo de água quente. Então, à vista de todos, mergulham-se os dedos na água fria, para dar a impressão de lavá-los, e ingere-se a água quente, que é gargarejada com ruído e cuspida no copo ou na tigela". Ao cair em desuso, banida sobretudo pelos ingleses, esta prática foi substituida por outra, descrita no Complete etiquette for gentlemen (Campbell s/d), em que uma ponta do guardanapo devia ser molhada na água morna perfumada com limão e passada nos lábios. Do mesmo modo os dedos deviam ser ligeiramente molhados e enxugados no guardanapo.

Este modelo de refeição pantagruélica, em várias cobertas, adentrou a primeira metade do século XIX, cercado de "imperiosas futilidades e importantes minúcias", como assinalou Horace Raisson em seu Code Civil - Manuel complet de la politesse, du ton, des manières de la bonne compagnie, de 1828 (código este que serviria de base, posteriormente, para o Manual do bom tom, publicado em 1872, no Rio de Janeiro, pelos Irmãos Laemmert), as quais era indispensável conhecer antes de se aventurar a aceitar um convite para jantar. No ano seguinte, em outra publicação intitulada Code de la conversation, manuel complet du langage élégant et poli, o mesmo autor descrevev o jantar como um drama em um ou mais atos, dependendo da economia ou generosidade do anfitrião. $O$ modelo francês previa três cobertas e mais de cinco era considerado "romântico", ultrapassando o número recomendado pelas regras clássicas. Esta composição em três atos - 
abertura, clímax e encerramento - acabou por tornar-se um padrão, amplamente adotado.

O jantar passou a ser governado por uma seqüência de regras extremamente rígidas, cuja ignorância ou desobediência eram consideradas imperdoáveis, precipitando o indivíduo no limbo da sociedade. De acordo com as normas dessa época, ou seja, nas primeiras décadas do século, um convite devia ser expedido com bastante antecedência, pelo menos oito dias antes do evento, de modo a poder ser transferido a outra pessoa em tempo hábil, em caso de recusa. Quanto maior o prazo, maior era a formalidade esperada para a cerimônia. Exigia-se uma pronta e categórica resposta, positiva ou negativa. Caso fosse aceito, tinha início então uma longa lista de deveres. A rigorosa pontualidade adquirida dos ingleses - a chamada hora militar- era o primeiro deles, para "evitar inconveniências" (Brillat-Savarin 1995: 175; O Fluminense 01/01/1882). Reunidos os convidados na sala visitas, um criado deveria anunciar "o jantar está servido". Nesse momento o anfitrião se levantava e oferecia o braço à dama de maior destaque entre os presentes, dirigindo-se à sala de jantar. Este gesto deveria ser imitado pelos demais cavalheiros e deste modo as senhoras eram conduzidas aos seus lugares à mesa, em geral marcados previamente por pequenos cartões colocados sobre os pratos. O cortejo era fechado pela dona da casa, levada pelo cavalheiro de maior proeminência no grupo.

Uma vez acomodados, o anfitrião anunciava o menu ${ }^{7}$ e, instalado no centro da mesa, servia a sopa nos pratos empilhados à sua frente, distribuindo-os primeiro entre os convidados à sua direita, depois à sua esquerda. Ao seu final, os pratos vazios com as respectivas colheres eram retirados pelos criados. As principais peças do jantar, os assados, eram trinchadas e servidas também por ele, que assim fazia as honras da casa. As demais travessas eram colocadas à mesa e todos se serviam livremente, inclusive dos vinhos, cujas garrafas eram postas nas suas extremidades, no caso de serem poucos convivas, ou a intervalos regulares em jantares maiores.

Na primeira coberta, ensinava Raisson, as pessoas deviam ser amáveis, porém "circunspectas e avaras de frases longas". Já na segunda, com o apetite em parte satisfeito, cabiam alguns comentários de bom gosto, anedotas agradáveis, mas nada que exigisse muita atenção ou reflexão, cabendo sempre lembrar que "os melhores contos são os mais curtos". Na terceira, já saciados, os convidados deviam elogiar o repasto e os vinhos. À sobremesa, com o senhor da casa liberado de quaisquer deveres, a conversação devia ser leve e alegre. Temas pesados, sérios, como política, religião, etc., eram de todo inconvenientes. Os brindes eram considerados pelos ingleses e norte-americanos como algo a ser evitado, próprio das classes inferiores. Admitidos apenas na mais estrita intimidade familiar, deviam limitar-se a um aceno, um sorriso ou olhar mais intenso, sendo vivamente desaconselhados, no início do século, pelo System of etiquette (1804) e em seus meados pelo The illustrated manners book.

Terminada a refeição, o anfitrião dava o sinal para que todos deixassem a mesa e se dirigissem à sala de visitas, onde era servido o café. Essa saída era feita por meio de um novo cortejo, só que agora o procedimento era invertido: iniciado pela senhora, era concluído por seu marido, o último a deixar o recinto. Os convidados deviam permanecer ainda por cerca de hora e meia, desfrutando
7. No século XVI, Montaigne, em seus Ensaios (1965: 63), atribuiu ao termo menu o significado de peu à peu, ou seja, pouco a pouco, tal como passaram a ser trazidos à mesa os alimentos, agrupados em sucessivas cobertas. 
a companhia dos anfitriões, para só então se retirarem.

As obrigações sociais não terminavam com o jantar e alguns dias depois devia ser feita a chamada visita de digestão, com a qual os convivas agradeciam as gentilezas recebidas, criando-se com ela a oportunidade para um novo convite.

Em meados do século, no entanto, uma importante mudança foi introduzida neste ritual: o chamado serviço à la russe, que revolucionou o comportamento à mesa, a estrutura da refeição, seu protocolo e as práticas culinárias.

As primeiras observações desse tipo de serviço foram feitas por Antonin Carême, em 1818, em sua passagem pela corte de Alexandre I. Muito prestigiado então, o primeiro dos grandes chefs do século XIX e autor de L'art de la cuisine française, o considerou inadequado à culinária francesa. Anos mais tarde, em 1830, o príncipe russo Kourakin, quando de sua permanência em Paris, mostrou aos franceses o novo método, ao recebê-los em seus banquetes. Em meados do século, as grandes festas da moda em Paris já adotavam o novo estilo, plenamente consagrado a partir de 1870, graças a Felix Urbain Dubois, que serviu como chef ao Príncipe Orloff, na Rússia, e que ao retornar a Paris popularizov-o em definitivo. A grande novidade introduzida foi o serviço dos pratos em sucessão e não mais simultaneamente, como dantes. As travessas de alimentos foram retiradas da mesa e depositadas em aparadores ou em apoios laterais, para serem oferecidas pelos criados aos convivas, um a um, à toda a volta. A tarefa de trinchar foi da mesma maneira transferida para o mordomo.

Com estas modificações foi decretado o fim dos enormes menus, que passaram a receber um tratamento seqüencial. Em função disso, os pratos diminuíram de diâmetro, na medida em que a comida era servida aos poucos e não de uma só vez (Lucas 1994: 84). A mesa de jantar, antes atulhada, ganhou novas possibilidades de utilização do seu espaço central, agora alvo de uma decoração esmerada. As antigas pirâmides de frutas foram substituídas por centros de mesa em porcelana, prata, bronze ou cristal, onde pontificavam flores frescas. Hardyment (1990: 7) reproduz, a partir do livro de Mrs. Benton, de 1861, 0 compêndio de culinária mais aceito à época, uma mesa arrumada para o jantar nesse novo estilo. Arranjos secundários eram dispostos ao longo da mesa, não raro misturados a frutas, cada vez mais incrementados em direção ao final do século, até o exagero, quando longas ramagens de trepadeiras e flores passaram a ser colocadas diretamente sobre as toalhas (prancha 1). Ao contrário do que ocorria na sua primeira metade, passou a haver um cuidado maior com o forte odor de flores e frutas, para evitar interferências no buquê do vinho, no paladar ou no apetite. As sobremesas ficavam expostas nos espaços intermediários entre os arranjos, desde o início do jantar, forçando a utilização de um mesmo serviço de louça ao longo de toda a refeição, de modo a evitar um efeito caótico e extremamente deselegante ao olhar.

As consequiências imediatas da adoção desse novo estilo foram a liberação do anfitrião para outras formas de entretenimento dos seus convidados; a diminuição do tempo de duração do jantar; a redução do número de iguarias servidas - que agora inclusive podiam ser consumidas mais quentes - mudando em qualidade e em quantidade a estrutura das cobertas e tornando o menu mais 
flexível; o aumento do número de criados para o serviço da mesa, na medida em que apenas uma pessoa não podia simultaneamente trinchar, administrar o aparador e servir a mesa. Isto tornou o modelo à la russe uma exclusividade dos segmentos mais afluentes da sociedade, tendo em vista que exigia serviçais muito bem adestrados, impecavelmente limpos e arrumados. Pela sua própria natureza, o serviço deveria ser rápido, eficiente, exigindo destreza, agilidade, movimentos discretos e absoluto silêncio, sem ruído de pratos e talheres, sinal de extrema vulgaridade. A proporção ideal recomendada pelo manual Waiting at table (By a member... $1894 \mathrm{~b}$ ) era a de um criado para três pessoas, três para nove e assim por diante, de tal modo que um jantar para um número maior de convidados exigia um grande staff. A ampliação das possibilidades decorativas, facilitadas pela eliminação da troca de toalhas a cada nova coberta, aliada ao esvaziamento da mesa, deram ao aparato de pratos, taças e talheres uma nova dimensão, passando essas peças a receber ainda mais destaque e atenção.

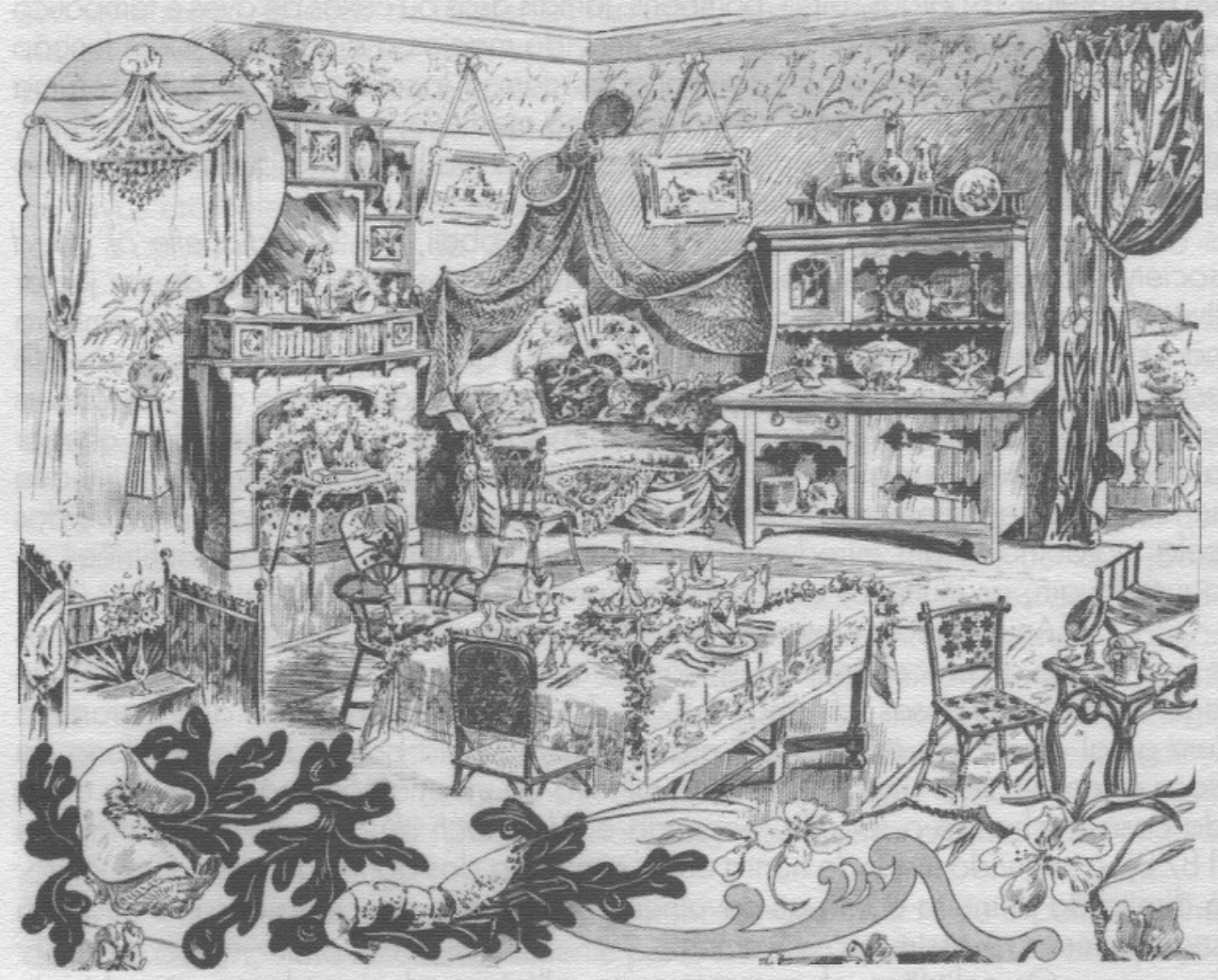

Prancha 1: Ao final do século, a profusa decoração de um interior já no estilo art nouveau, publicada como sugestão no jornal $O$ Brazil Elegante, de 5 de fevereiro de 1898. Num ambiente que reúne as funçōes de sala de visitas e de jantar, a contradição da lareira em um país tropical, rivalizando em importância com a principal peça da sala, um éfagère que exibe louças de família. Sobre a mesa esparramam-se cordōes de flores, delimitando campos para os pratos com guardanapos em mitra e para a oposição simétrica das jarras d'água e garrafas de vinho. 
8. A extensão dessa mudança pode ser avaliada através da comparação do menu prepa rado por Carême, em 1817 , no Royal Pavillion, e o feito por Escoffier para a coroação de George $V$, no início do século XX, como mostrou Tannahill (1988: 303).

9. Marcel Proust, no volume "À sombra das raparigas em flor" de sua obra Em busca do tempo perdido (1957: $95 \mathrm{e}$ 118), mostrou o desconforto a que se expunham aqueles que não dominavam esses códigos: "No momento em que devia passar da antecâmara para o salão, o mestre-sala entregou-me um envelope fino e longo onde estava escrito o meu nome. Na minha supresa, agradeci-lhe, enquanto olhava para o envelope. Sabia tanto o que devia fazer com ele como um estrangeiro com um desses pequenos instrumentos que dão aos convivas nos jantares chineses. Vi que estava fechado, tive receio de parecer indiscreto se o abrisse imediatamente e meti-o no bolso com ar de entendido (...). Entrementes já havíamos passado para a mesa. Encontrei ao lado de meu prato um cravo, com o caule envolto em papel de estanho. Não me perturbou tanto como aquele envelope que me haviam entregue na antecâmara e que eu esquecera completamente. Também o destino daquele cravo me era desconhecido, mas pareceu-me mais inteligivel
A estrutura da refeição, agora mais leve e interessante, com o conteúdo das cobertas mais especializado, passou a compreender em primeiro lugar a sopa, precedida apenas pelas ostras, no caso de constarem do menu. Seguiam-se os peixes, as entradas, os assados, as aves e finalmente as sobremesas e 0 café. Segundo Le Savoir Vivre (Alq 1877), as sobremesas deviam ser servidas na seguinte ordem: queijos, frutas, doces e sorvetes ${ }^{8}$. Uma versão resumida da clássica composição em três cobertas foi adotada no âmbito familiar, consagrando o modelo "sopa/prato principal e dois acompanhamentos/sobremesa", com a tripartição se manifestando também na própria coberta central.

As regras para a ingestão dos alimentos podiam ser distribuídas do mesmo modo em três categorias: o que devia ser consumido com talheres, o que devia ser consumido com as mãos e o que devia ser consumido com alimentos inertes (pães, biscoitos, etc., como suportes). Massas, saladas, legumes, tubérculos, só podiam ser ingeridos com garfo, nunca com o auxílio da faca. Azeitonas, com colheres. As mãos só podiam tocar determinados alimentos, como pão ljamais partido com faca ou mordido diretamentel, biscoitos, certos tipos de frutas, como uvas e cerejas, aspargos, aipo, bombons. Jamais asas ou coxas de aves e tampouco queijos, que percorriam uma ampla gama, de macios a duros. Estes, em função de seu forte aroma, deveriam ser cortados com a faca e colocados sobre uma fatia de pão, que funcionava, assim como no medievo, como um alimento inerte, ou seja, um elemento intermediário entre as mãos e a boca. Naquele caso, como prato; aqui, como uma espécie de talher.

Mais ao final do século, Lady Campbell, em seu Etiquette of good society (1893: 135), recomendava vivamente que os participantes de um jantar tivessem a mesma posição social e que se movessem nos mesmos círculos, embora não precisassem ser necessariamente amigos. $O$ ritual, após a introdução do estilo à la russe, passou a ter a seguinte configuração: de acordo com o Manners and rules of good society (By a member... 1892), os convidados deveriam chegar até cerca de quinze minutos depois da hora marcada; a pontualidade continuava sendo muito recomendada como sinal de boa educação e polidez. Recebidos pelo mordomo, eram introduzidos até a sala de visitas, onde os anfitriões os aguardavam, as mulheres andando ligeiramente à frente dos homens.

Anunciado o jantar por um criado, formava-se o cortejo com as mesmas e sutis regras de precedência descritas para a primeira metade do século, só que agora mais minuciosas (cf. Anon 1872: 16-8). A dama de mais alta hierarquia (em geral a senhora mais idosa) era conduzida pelo braço direito do dono da casa e sentava-se à sua direita. O cavalheiro da mesma condição levava a dona da casa, fechando o séquito. Segundo o Almanach du Savoir Vivre (Baffanville 1878), o segundo lugar de honra era à esquerda dos donos da casa. O terceiro, à direita da primeira dama ou cavalheiro depois dos donos da casa, o quarto à sua esquerda, e assim sucessivamente.

Os anfitriões informavam os cavalheiros sobre as damas que deviam conduzir, não havendo qualquer possibilidade de escolha'. Os lugares eram indicados verbalmente ou por pequenos cartões colocados sobre o guardanapo ou em graciosos porta-cartões. Segundo o Le Savoir Vivre, podiam ser comprados prontos "cartõezinhos encantadores com finos desenhos a aquarela". Não raro eram impressos nos menus colocados à frente dos convidados, em toda a extensão 
da mesa. Indispensáveis nos jantares maiores, soavam pretensiosos nos de menor porte. De acordo com esse manual e também com o Etiquette for gentlemen, anfitrião e anfitriã sentavam-se em geral no centro da mesa, mas sempre em posições opostas, de frente um para o outro, de modo a que pudessem presidir os serviços e a conversação.

Ao entrarem no salão, os convidados já encontravam a sopa servida em seus pratos, que jamais era oferecida pela segunda vez. $O$ ambiente deveria estar adequadamente iluminado e o Waiting at table chegava a recomendar 20 velas de cera para iluminar uma mesa de dezesseis pessoas. A toalha, em linho adamascado "branco como a neve", deveria estar impecável, sem dobras ou rugas, e rigorosamente centrada na mesa. Em cada lugar ou coberta, os diversos talheres adequados a cada alimento eram dispostos na seqüência em que deviam ser utilizados: facas e colheres à direita, garfos à esquerda. Uma regra importante determinava que não poderiam ser colocadas mais que três facas em cada lugar, sempre com a lâmina voltada para dentro.

Os talheres de sobremesa não eram colocados senão no momento da sua utilização. As taças de diferentes formatos, destinadas aos variados tipos de vinhos servidos de acordo com as cobertas, eram postas ligeiramente acima do prato, à direita. O pão era enrolado no guardanapo, agora definitivamente livre das fantasiosas dobraduras dos séculos anteriores. O modelo em voga na segunda metade do século era em forma de mitra ov em meia esquadria. Para cada par de convivas era colocado um saleiro e para cada conjunto de quatro pessoas, uma jarra d'água. As garrafas de vinho foram suprimidas da mesa no serviço à la russe, sendo as bebidas servidas diretamente pelo mordomo.

Os antigos valores comunais, claramente visíveis no serviço à la française, foram abandonados. $O$ individualismo era a marca do novo estilo, no qual cada um tinha seu próprio espaço, demarcado pelo conjunto de pratos, talheres, copos e guardanapo, a uma distância absolutamente regular dos vizinhos de mesa, fixada em alguns manuais com a precisão de centímetros. O Le savoir vivre recomendava 60 a $70 \mathrm{~cm}$ de intervalo entre um lugar e outro, o mesmo que - Table service (Allen 1915), enquanto o Manuale completo di cucina... (Bossi 1894) determinava que cada conviva deveria ocupar não menos que $80 \mathrm{~cm}$. Esse equipamento passou a ser rigorosamente pessoal e um tather individual não podia tocar, de modo algum, o que fosse comum aos demais convivas, como travessas, saleiros, molheiras, etc. Invadir o espaço alheio, ultrapassar esse "território invisivel" passou a constituir uma transgressão intolerável. Inclinar-se, expandir-se com os cotovelos, esticar os braços e as mãos para pegar algo tornou-se uma incivilidade (Franklin 1889: 263), verdadeira heresia, uma afronta aos preceitos do ritual Uameson 1987).

Em seguida à sopa, que devia ser tomada sem ruído e com a cother de lado, o serviço era feito integralmente pelos criados, sem qualquer participação do dono da casa. As travessas vinham diretamente da cozinha e o aparador ou a mesa lateral de apoio funcionavam como base de operações. Aí ficavam também talheres de servir, pratos sobressalentes, garrafas de vinho, lavandas, pratos e tatheres de sobremesa. Os grandes peixes e os assados, agora trinchados pelos criados, eram antes apresentados à mesa inteiros, em sua plenitude, saboreados com os othos, e após um sinal de aprovação do dono da casa, desarticulados e servidos. quando vi que todos os convidados do sexo masculino se apoderavam dos cravos que acompanhavam seus respectivos talheres e os enfiavam na botoeira da sobrecasaca. O mesmo fiz eu, com essa naturalidade do livre-pensador na igreja o qual não entende a missa, mas levanta-se com os outros e ajoelhase um pouco depois que os restantes (...). Depois de deixar meus pais, fui mudar de roupa e, esvaziando os bolsos, dei com o envelope que me entregara o mestre-sala dos Swann ao me introduzir no salăo. Estava sozinho agora.Abri-o; no interior havia um cartão em que me indicavam a dama a quem devia oferecer o braço para ir à sala de jantar". 
10. Em um jantar íntimo, familiar, com poucos criados, a dona da casa era a primein a ser servida, seguindo-se suas filhas, por ordem de idade; a preceptora quando presente; o dono da casa e seus filhos, igualmente por ordem de idade. Admitia-se, nessa circunstância, que as travessas fossem colocadas diante do dono da casa, que partilhava os alimentos entre os membros da família. O senhor ou a senhora podiam servir a sopa, segundo o Waiting at table; enquanto o pei$x e, o$ assado $e$ as aves cabiam apenas ao senhor e a sobremesa à senhora.
Os alimentos eram apresentados sempre pelo lado esquerdo - uma regra severa - e apenas os vinhos eram oferecidos pelo direito. A primeira a ser servida era a senhora à direita do anfitrião, continuando pela ordem em que os convidados estavam sentados, senhoras e senhores alternadamente, independente de sexo e de idade, já que atender em primeiro lugar a todas as senhoras causaria enorme confusão, vaivém e grande perda de tempo ${ }^{10}$.

Uma das mais sotisticadas e requintadas formas de uso dos talheres foi introduzida pelos ingleses: a faca era mantida na mão direita e o garfo à esquerda, com os dentes voltados para baixo. A comida era acumulada nas costas do garfo com o auxílio da faca e, numa demonstração de grande equilíbrio, levada até a boca. Até hoje em voga como elemento de diferenciação, esta prática requer considerável treinamento e destreza. As facas só eram mantidas nas mãos enquanto estivessem ativas, devendo ser pousadas assim que cessasse sua utilidade. Descansos de talheres, em louça ou metal, eram colocados à mesa para que garfos e facas aí permanecessem durante a troca de pratos, sem macular a alvura da toalha.

Não se devia comer nem muito rápido, de tal maneira que fosse preciso esperar pelos demais, nem muito lentamente, de modo a que atrasasse o serviço. Só em casos excepcionais se devia louvar uma iguaria servida, na medida em que se esperava sempre o melhor de um anfitrião. O excesso de elogios poderia sugerir que o cardápio cotidiano do dono da casa não comportava comidas mais finas ou então que se esperava um jantar mais simples, ou mesmo que o conviva não estava acostumado a uma boa mesa.

Após cada coberta os pratos eram removidos e substituídos, o que obrigava à utilização de um grande número dessas peças em cada refeição. Para a sobremesa era retirado tudo o que se referisse às cobertas anteriores: pratos, talheres, taças, saleiros, jarras d'água, etc. O prato da anfitriã devia ser sempre o último a ser levado, de modo a jamais sugerir que era chegado o momento de se parar de comer. Tendo em vista que a sucessão de toalhas não era mais adotada a essa altura, farelos e migalhas eram recolhidos com facas de prata ou madeira, ou com escovas próprias. As lavandas continuaram sendo trazidas ao final da sobremesa, colocadas à esquerda, com água morna ligeiramente perfumada com menta, limão ou pétalas de rosa; só que agora destinadas a molhar apenas ligeiramente as pontas dos dedos, após o consumo de frutas e queijos, com um caráter mais ornamental e simbólico que propriamente utilitário, acompanhando a intensificação do processo de higienização na segunda metade do século.

Ao final do jantar, a anfitriã inclinava ligeiramente a cabeça para a dama de mais alta hierarquia e levantava-se, sendo de imediato acompanhada pelas demais. Os guardanapos deviam ser deixados displicentemente desdobrados sobre a mesa. Segundo alguns manuais, como o le savoir vivre, a dona da casa agora iniciava o cortejo de saída, que se encerrava com seu marido, o último a deixar o recinto. Segundo outros, como o Manners and rules of good society, todos saíam na mesma ordem em que entraram. Uma variante inglesa, apresentada em The ways of sociely - a social guide (Danvers s/d: 32) e também referida por Burnett (1989: 201), permitia que apenas as senhoras fossem para a sala de visitas, onde thes era servido o café, enquanto os cavalheiros permaneciam na 
sala de jantar para, à volta do anfitrião, conversarem, fumarem e também tomarem café. Já entre os franceses era mais comum a permanência de todos na sala de visitas. Música e jogos de cartas eram proporcionados aos convidados, que não deviam permanecer por muitas horas a mais na residência após o jantar, retirando-se no máximo duas horas após o seu início. $\bigcirc$ anfitrião acompanhava seus convidados até a porta, onde eram aguardados pelas carruagens, previamente anunciadas.

A visita de digestão continuava a ser obrigatória, tal como na primeira metade do século, uma semana ou no máximo dez dias após o jantar. Caso os anfitriōes não fossem encontrados em casa, deviam ser deixados cartões como testemunho da visita e expressão de agradecimento. Mesmo o convite recusado requeria a visita e a inobservância desse preceito podia determinar até o rompimento de relações.

Os almoços, por sua vez, continuaram sendo considerados refeições absolutamente informais, onde os amigos mais chegados podiam chegar inesperadamente, sem convite especial, o que era visto como algo prazeroso e agradável. Só raramente era utilizado, nessa circunstância, o serviço à la russe, sendo mais comum o serviço "parcialmente" d̀ la russe, no qual as carnes mais leves eram colocadas sobre a mesa e os assados na mesa auxiliar ou aparador.

No último quartel do século o novo estilo estava totalmente disseminado nas esferas mais altas (Baffanville 1878: 78; Danvers s/d: 31 ) $^{11}$. Mesmo assim, essas mudanças foram adotadas em ritmos bastante diferenciados: a nova moda não penetrou de pronto em todos os espaços e em alguns lares mais conservadores foi mantido ainda por um bom tempo o antigo serviço à la française.

À mesa, no Rio de Janeiro oitocentista

"Como quer começar? À francesa pelo peixe, ou cá à nossa moda brasileira, pelo cozido?" José de Alencar, em Sonhos d'ouro'

A análise de códigos de civilidade e boas maneiras permite entrever o comportamento idealizado pela sociedade que os produz ou utiliza. As práticas reais, efetivas, entretanto, podem não corresponder a esse modelo concebido como o mais satisfatório e adequado, de tal forma que, para acessar as condutas à mesa no Rio de Janeiro do século passado, foram consultados, além desses manuais, romances, contos e crônicas de época, bem como os clássicos registros e memórias de viagens dos estrangeiros que por aqui passaram.

Do confronto entre essas fontes emergiram dois perfis claramente diferenciados de comportamento: um, resultante da importação do modelo franco-inglês, adotado pelas camadas mais altas da sociedade para "consumo externo", visando seu próprio reconhecimento e legitimação. $\bigcirc$ outro, inequivocamente relacionado ao processo colonizador e fortemente influenciado pelos hábitos portugueses, acabou constituindo o modelo por excelência para "consumo interno", compondo o dia-a-dia dos segmentos médios da população.

Os manuais de etiqueta portugueses do século passado, apesar de calcados nos códigos ingleses e franceses, foram resultantes de adaptações das normas ai contidas aos hábitos lusitanos. É inequívoca a inserção de recomendações quanto a determinados procedimentos que há muito haviam sido
11. O filme Na época da inocência, de Martin Scorcese, mostra o ritual do jantar no século XIX, esplendidamente servido à la russe, como um poderoso instrumento de mediação, negociação e delimitação social.

12. Cf. Alencar (1959a: 799). 
13. Nizza da Silva (1978: 19) refere-se a uma $e$ dição anterior, de 1814 . banidos daqueles dois países (tanto que não existe qualquer alusão a elas nos manuais lá produzidos à mesma época), mas que, enquanto reminiscências de antigos modelos, ainda persistiam em Portugal.

Em Escola de Politica ou Tratado prático da civilidade portuguesa (Siqueira), edição de $1845^{13}$, há disposições ora concordantes, ora discordantes do modelo franco-inglês. Uma delas referia-se ao lugar do senhor da casa à mesa que, segundo o texło, "é onde lhe parece, mas nunca os melhores". Considerava-se então que o mais honrado era o da cabeceira à direita dos convidados, devendo o anfitrião designar os assentos, após conduzir os convivas segundo suas graduações. Alusões ao uso estrangeiro de entresachar cavalheiros e damas, mostram que o costume começava a ser adotado em Portugal a essa época.

Cabia ao anfitrião ou a um dos seus convidados trinchar os assados e servirthes os pratos. Era uso colocar-se em cada lugar à mesa três pratos empilhados $e$, no caso de haver sopa, o primeiro deveria ser covo (fundo). Não obstante, recomendava-se a colocação de um único prato, e, dentro dele, o guardanapo bem dobrado, contendo em seu interior os três talheres e o pão.

Enquanto na' Inglaterra e na França, em meados do século, os guardanapos eram simplesmente pousados sobre os joelhos, em Portugal, com grande defasagem, ainda se recomendava colocar uma das suas pontas sobre a mesa e a outra na altura do peito, para resguardar as roupas, como se os comensais a esta altura continuassem babando, cuspindo e entornando os alimentos sobre si mesmos, como no medievo. Outra prática singular consistia em "pôr um cartão sobre os punhos para que estes não se amarrotassem com o movimento dos braços", ao comer (Correio das Damas 1836). Ainda se observava ser "indecente limpar com ele lo guardanapol o prato, indecentíssimo leváto ao nariz ou ao rosto para enxugar o suor", atitudes já impensáveis naqueles países, mas ainda praticadas em Portugal, haja visto a imperiosa necessidade de coibi-las. Não era considerado muito grave palitar à mesa, porém o palito não devia ser "deixado na boca, (...) no cabelo, atrás da orelha, na casaca". Não se devia "fazer saco na boca, não a encher muito", nem tampouco "fazer ação que caus(asse) nojo". No que dizia respeito aos brindes à refeição, assinalava que "já hoje vai se desterrando o costume de fazer saúdes".

Três décadas mais tarde, em 1877, A sciencia da civilização (Pimentel 1877) considerava "mais distintos os lugares do centro da mesa e destes o que fica em frente da porta que dá serventia à sala, sendo os da cabeceira os menos distintos. A dona da casa senta-se em frente à porta, e os dois cavalheiros mais distintos de um lado e outro, em frente dela senta-se o marido e as damas e cavalheiros por toda a mesa, sendo os logrados tanto mais distintos quanto mais próximos da dona e dono da casa, referindo os da direita aos da esquerda". Prosseguiam admitindo o uso do palito, mas frisando que jamais ele deveria ser colocado "por cima da orelha". A prática de enxaguar a boca ao fim do jantar, lançando-se a água servida numa pequena taça redonda, era tida aí como pouco asseada, recomendando-se a sua extinção. As saúdes continuavam fora de moda. Não se devia fazer grandes elogios à comida e sobretudo "jamais cair na miséria de arrecadar coisa alguma" da mesa. Era bastante enfatizada a necessidade da visita de digestão e em linhas gerais as recomendações estavam bem mais próximas 
dos manuais ingleses e franceses que o Tratado prático da civilidade portuguesa, de meados do século, sinal de que ao menos nas áreas urbanas os velhos e antihigiênicos costumes estavam sendo abandonados.

Praticamente contemporâneo, o Compêndio de civilidade cristá (Costa), de 1880, seguia ainda mais de perto o modelo franco-inglês. Recomendava "comer em casa como se estivesse em um jantar de cerimônia (...)", na medida em que desta forma os bons modos "se lhes tornavam fáceis e como naturais, aparecendo em público como decência, desembaraço e urbanidade, próprios de cavalheiros finos e cortezes". As pessoas deviam "ter cuidado de não incomodar com os braços os vizinhos", "não servir das travessas com o mesmo talher de que se serve", ou seja, assumindo plenamente o exacerbado individualismo à mesa. Continuavam as advertências para que não "conversa(ssem) com o palito na boca, não o guarda(ssem) atrás da orelha ou no cabelo", nem tampouco "enche(ssem) as algibeiras do que não pudelssem/ comer". Esta instrução se manteve até o início do século XX, aparecendo no Manual de civilidade e etiqueta (Nazareth 19141, premiado na Exposição do Rio de Janeiro, em 1908, nos seguintes termos: "Será faltar à cortesia e provar desconhecer os mais rudimentares preceitos da civilidade arrecadar na algibeira frutas, bolos, palitos, etc., que sobejem da sobremesa (...)".

Estes eram os referenciais de que dispunha a sociedade carioca para balizar seu comportamento à mesa. Romances, contos e crônicas escritos à época, no entanto, ao colocarem as ações de seus personagens no dia-a-dia do Rio de Janeiro oitocentista, expressavam de que maneira essas regras eram absorvidas, adaptadas, retrabalhadas ou refugadas por aqueles que, a rigor, deveriam adotátas como modelo ideal de conduta. Os estrangeiros que por aqui passavam, ao relatarem suas impressões sobre o que viam, reproduziam os comportamentos observados. Esses registros, não obstante eivados de preconceitos, atuaram como complemento ou reforço, conforme o caso, da reconstituição feita a partir da literatura de ficção, desconsiderando-se os juízos de valor neles contidos, quando não comprovados por outras fontes.

Para as primeiras décadas do século, Machado de Assis ofereceu em Memórias Póstumas de Brás Cubas, numa retrospectiva de infância do personagem principal, uma descrição de um jantar comemorativo, na residência da família: "Veio abaixo toda a velha prataria, herdada de meu avô, Luis Cubas; vieram as toalhas de Flandres, as grandes jarras da india; matou-se um capado, encomendaram-se às madres da Ajuda as compotas e marmeladas; lavaram-se, arearam-se, poliram-se as salas, escadas, castiçais, arandelas, as vastas mangas de vidro, todos os aparelhos do luxo clássico. (...) Era à sobremesa; ninguém já pensava em comer. No intervalo das glosas corria um borborinho alegre, um palavrear de estômagos satisfeitos; os othos moles e úmidos, ou vivos e cálidos, espreguiçavam-se ou saltitavam de uma ponta à outra da mesa, atulhada de doces e frutas. Aqui o ananás em fatias, ali o melão em talhadas, as compoteiras de cristal deixando ver o doce de côco, finamente ralado, amarelo como uma gema, - ou então o melado escuro e grosso, não longe do queijo e do cará" (Machado de Assis 1946b: 53-6).

Outro relato, feito por Maria Graham, em 1821, descreve uma refeição em uma "magnífica casa" brasileira, com belíssimos aposentos onde pontificavam 
14. Extraido de Machado de Assis: 14a. Contos fluminenses I (1944d: 291); 14b. Quincas Bon ba (1946c: 57).

15. Extraído de José de Alencar, Senbora (1995a: 207).

16. Extraído de Machado de Assis: 16a. Histórias da meia noite (1942: 210); 16b. Ressurreição (1944a: 13); 16c. Histórias da meia noite (1942: 111); 16d. Contos fluminenses $\mathrm{H}$ (1944d: 308); 16e. Memorial de Ayres (1944c: 26); 16f. Historias da meia noite (1942: 111); $16 \mathrm{~g}$. Histórias sem data (1944g: 92); 16h. Páginas recolbidas (1944i: 59). louças da China e relógios franceses: "O jantar foi pequeno, já que só havia três pessoas, mas servido excelentemente. Consistiu em sopa de ave selvagem, uma série de pássaros pequenos e doces do país, que eram para mim raridades. 0 resto do jantar, que poderia ser inglês ou francês, foi servido em baixelas de prata" (Graham 1990: 273).

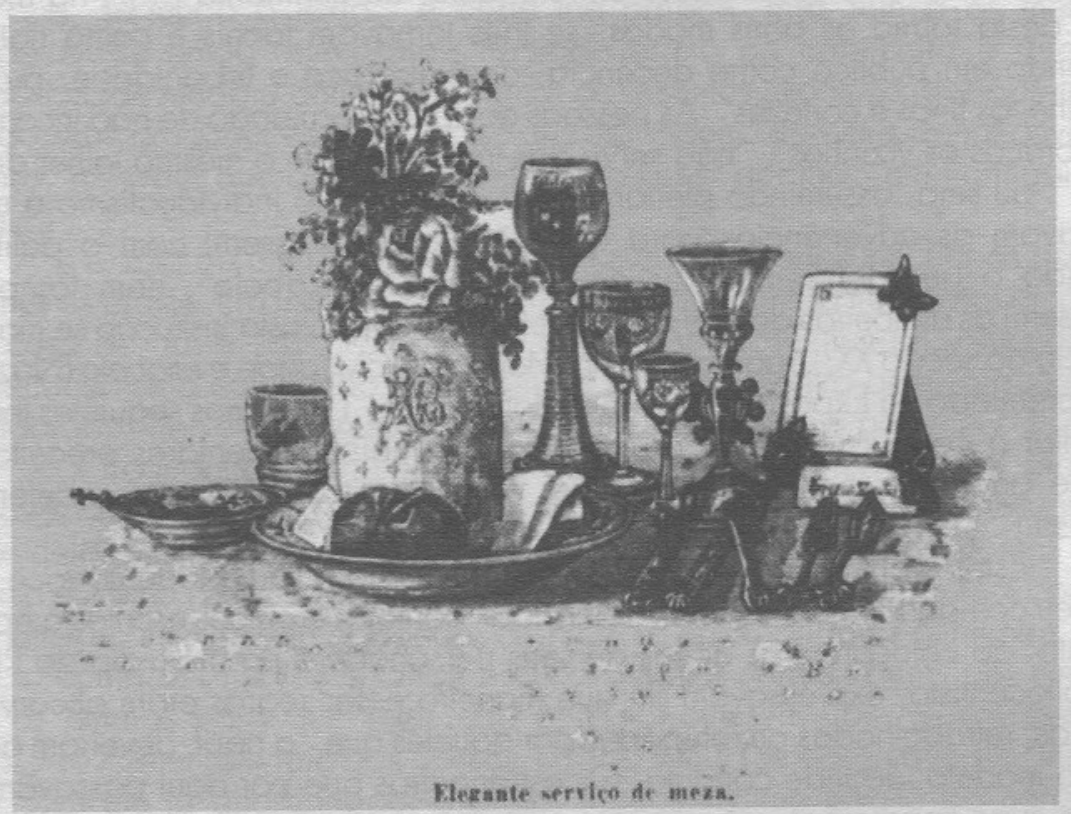

Prancha 2: Sugestão de arranjo de mesa com menu, porta-cartões e porta-talheres, publicado no periódico A Estação, de 30 de setembro de 1887

Para meados do século, com base em trechos diversos extraídos de diferentes autores e fontes, pode-se traçar as linhas mais gerais do cerimonial que regia os jantares festivos. Os convites eram feitos pessoalmente ou por escrito, levados ao destinatário pelo preto da casa ou por um moleque. Exigia-se a pronta resposta, sendo inadmissível a ausência, uma vez aceito o convite. Em situações extremas, mandava-se um representante (Machado de Assis 1944a: 57).

Chegados os convidados, o jantar era anunciado nas classes dominantes em geral por criados europeus: alemães ${ }^{14 a}$, espanhóis ${ }^{14 b}$, ou mesmo por mucamas ${ }^{15}$. $O$ preto da casa $^{16 a}$ ou um moleque ${ }^{16 b}$ também exerciam essa tarefa, sobretudo entre as camadas médias. Atendendo ao chamado da anfitriã, dirigiam-se então à sala de jantar, em cortejo conduzido, conforme o modelo europeu, pelos donos da casa. Entre as camadas médias, entretanto, os critérios hierárquicos eram os mais estapafúrdios: ora o dono da casa dava o braço simultaneamente a duas convidadas, seguindo os demais em procissão ${ }^{16 c}$, arranjada na hora e segundo as escolhas e conveniências do momento ${ }^{16 d}$, ora respeitava-se critérios como prestígio social, idade ou afetividade ${ }^{160}$. Essa caminhada era feita com grande expectativa, tendo em vista que "não há mais júbilo nos peregrinos de Meca do que nos convivas ao avistarem uma longa mesa, profusamente servida, 
lastrada de porcelanas e cristais, assados, doces e frutas" 16 .

Menus escritos eram de praxe nos jantares de maior cerimônia ${ }^{16 g}$, mas singelas adaptações podiam ser encontradas, por exemplo, no almoço dominical de um casal de poucos recursos, morador de uma pequena casa de Santa Tereza, com um jardim pouco maior que ela, ao receber apenas um amigo: "a mulher estava acabando de arraniar as flores e folhagens que tinham de adornar a mesa. Além disso e do mais, adornava cartões, contendo a lista dos pratos, com emblemas poéticos e nomes de musas para as comidas. Nem todas as musas podiam entrar, eles não eram ricos, nem nós tão comilões; entravam as que podiam" ${ }^{\prime b h}$.

À mesa, coberta por uma toalha adamascada (A familia 1889), os donos da casa algumas vezes ocupavam a cabeceira, tal como visto na primeira metade do século Machado de Assis 1946a: 32; A vida fluminense 1868: 141). Mais para as décadas finais, no entanto, uma outra distribuição passou a ser também admitida: os donos da casa sentando-se juntos, ladeados respectivamente pelos dois convidados de sua maior consideração (Machado de Assis 1944c: 26). A ordenação rigidamente hierárquica dos convivas nem sempre era seguida, bastando determinar o assento dos dois principais. Em um conto - $O$ Jantar-publicado em 1854, no Novo Correio de Modas, a anfitriã assim os colocava: "Podem assentar-se que o jantar vem já; este lugar à esquerda da sra. Adelaide é mev; este da direita é para o sr. Manuel Henrique, os mais senhores queiram fazer como costumam quando me fazem a honra de jantar comigo, assentem-se onde quiserem".

Em um trecho de A Moreninha, de J. M. de Macedo (1981: 31 1, uma referência às "primeiras cobertas" |"Durante as primeiras cobertas ela dissertou maravithosamente acerca de suas companheiras") deixa entrever que na primeira metade do século as refeições eram feitas em muitas etapas.

Ao final da década de 1860, as principais peças dos jantares festivos - quase sempre perus e leitões - já estavam sendo trinchadas fora da mesa, atestando a penetração, no Brasil, do serviço à la russe. Não obstante, mantinham-se algumas resistências, sendo a tarefa confiada a um dos convidados (Revista Popular 1861: 68). Em um jantar para 25 pessoas, na casa de um desembargador lausente, em viagem), a dona da casa pediu a um cônego convidado que trinchasse a ave, já que ela "acatava esse uso nacional das casas modestas de confiar o peru a um dos convivas, em vez de o fazer retalhar fora da mesa por mãos servis $(. .$.$) .$ Ninguém conhecia melhor a anatomia do animal, nem sabia operar com maior presteza" (Machado de Assis 1944f: 155-6).

A descrição de uma ceia à meia noite por José de Alencar, em Lucíola (1995c: 34-5), "suntuosa e delicada", não deixa dúvidas quanto à plena adoção, entre os estratos mais elevados, do serviço à la russe: "A mesa oval, preparada para oito convivas, estava colocada no centro sobre um estrado, que tinha o espaço necessário para o serviço dos criados. (...) Os aparadores de mármore cobertos de flores, frutos e gelados, e os bufetes carregados de iguarias e vinhos, eram suspensos à parede".

Burmeister queixou-se amargamente, em 1850-51, das maneiras aqui adotadas: "No Brasil costuma-se comer rapidamente. Mal se tem tempo para engolir o último bocado de comida e já um escravo retira o prato, substituindo-o por outro limpo. Na mesa, cada um se serve como quer daquilo que mais the 
17. Extraido de Machado de Assis: 17a. Histórias da meia noite (1942: 58-60 e 97); 17b.Ib. (1942: 115); 17c Várias bistórias (1944h: 178); 17d. Papéis avulsos (1944f: 231); 17e. Memorial de Ayres (1944c:208); 17f. Várias bistórias (1944h: 178); 17g. Histórias da meia noite (1942: 113); 17h. Contos fluminenses II (1944d: 308-10); 17i. Relíquias de Casa Velba I (1944j: 276); 17j. Histórias da meia noite (1942: 118).

18. No conto "Um jantar de mancebos" (Novo Correio de Modas 1853: 204)

19. Para mais referências às "saúdes cantadas", ver Cascudo (1983: 738-55). agrada; e assim, vai-se consumindo um prato após outro até que o dono da casa se levanta, dando por terminada a refeição" (Burmeister 1952: 172).

As sobremesas, uma impressionante variedade de doces e frutas tropicais, eram em alguns casos servidas em outra sala contígua, especialmente arranjada para esta finalidade (Novo Correio de Modas 1854: 10). Este era o momento do brinde, tão apreciado entre as classes médias, feito em geral por um dos convivas ao dono da casa e seus familiares, louvando-thes as virtudes, apesar de rigorosamente condenado pelos manuais de bom tom europeus.

Os chamados oradores de sobremesa, conhecidos por sua verborragia, costumavam ser convidados precipuamente para esta finalidade. Qualquer ocasião ou circunstância era pretexto para as saúdes, descritas por Saint-Hilaire, em 1819 , como uma das praxes "mais incômodas que se possa imaginar" (Saint-Hilaire 1975): desde um jantar comemorativo ${ }^{17 a}$ a aniversários, noivados, casamentos ${ }^{17 b}$, festas de São João ${ }^{17 c}$ e ceias de Natal ${ }^{17 d}$. Entre pessoas de melhor nível, se a ocasião assim o exigisse, o brinde era feito discretamente, com poucas palavras ou um simples aceno de cabeça ${ }^{17}$. Apreciados por uns ("vamos, uma saúde, seu diplomático... faça uma saúde daquelas..." $77 \mathrm{f}$, "uma saúde historiada"17g, "um brinde de copo batido"17h, eram execrados por outros /"um longo discurso, arrastado, cantado, assoprado, cheio de anjos, de um ou dois sacrários de caras esposas, acabando tudo por um cumprimento ao nosso venturoso amigo. Vieira, interiormente, mandou-o ao diabo; mas, levantou o copo e agradeceu sorrindo" 17 i). Se a platéia estava estimulada e os assuntos esgotados, recorria-se a "um brinde ao exército e seus generais (...), à união das províncias do império (...), ao progresso do mundo por meio do café e do algodão (...), ao estabelecimento da paz universal"17i. E ainda: "À saúde da prudência das mulheres!", ou, conforme o brado de um banqueiro, "À saúde do comércio!"18.

Richard Burton, em sua passagem pelo Brasil em 1867/68, descreveu um jantar no interior onde "todas as espécies de 'saúdes' foram bebidas e tornadas a beber", frisando que no litoral a regra era a "discurseira" portuguesa e interrogando: "Que diria disso o sapiente autor da Arte de jantar (Burton 1976: 143)? O hábito era tão arraigado e a pressão para o seu reconhecimento tão forte, que na transição para o século XX o Manual de civilidade e etiqueta mencionava: "Tem se pretendido fazer renascer a velha moda dos choques nos copos, mas ainda não está readaptada"19.

O excesso de elogios à qualidade das iguarias era considerado de mau gosto, tal como na Europa, de modo que uma mulher, ao ver seu marido elogiar pela terceira vez uma gelatina em um jantar, "tão envergonhada ficou com estas palavras que não pode reter um gesto de desgosto" (Machado de Assis 1942: 1131.

Burmeister, em suas críticas, referiu-se a um "hábito muito desagradável, com o qual nunca pude me conformar; é o de bochechar depois da refeição. Cada um toma um gole d'água, agita-o na boca e depois cospe" (Burmeister 1952: 128). Nos centros urbanos, cuspia-se na já referida taça, enquanto no interior cuspia-se no chão. Em 1861, um artigo da Revista Popular protestava vivamente contra esta prática, "indecente e nauseosa". Fazendo um histórico do costume desde o início do século, quando era mais discreto, discorria sobre a introdução desta nova variante nos seguintes termos: "(...) aparecem no fim da 
sobremesa criados, que distribuem aos convivas taças cheias de água fria, no meio das quais vem um copinho com água morna. Então, à vista uns dos outros, mergulham-se os dedos na água fria, fingindo lavá-los, e enche-se a boca com a morna, gorgolejando com ruido e vomitando-a depois na taça". Considerada uma "afetação de asseio pretenciosa, que não está nos nossos gostos, nem nos nossos hábitos" - uma possível alusão à origem francesa - propunha a sua extinção, porque "não deve o que uma vez entrou pela boca, tornar a aparecer às vistas dé ninguém" 20

Ewbank relatou, em 1845, que todas as refeições aqui terminavam "passando-se à roda o paliteiro, curiosa peça de prata para servir palitos de pau de laranjeira. Não pouco engenho se revela na fabricação deste objeto: ora figura um caititu ou um ouriço nos quais os palitos representam as cerdas ou espinhos; ora um disco solar, em que os palitos são os raios; ou um abacaxi, seguro por um Apolo (...)" (Ewbank 1973: 811). Duas décadas mais tarde, Burton ainda se referia a esta peça como uma das peculiaridades da mesa brasileira, nos seguintes termos: "o paliteiro, de formato esquisito (...), aflige a pouca experiência germânica. $\bigcirc$ povo do nosso País freqüentemente sai de casa com um profundo desprezo pelo pequeno palito, que considera um modo de limpeza pouco higiênico. Em poucos meses, contudo, descobre que o palito é indispensável nos trópicos, mas, não tendo aprendido a utilizá-lo, de modo algum está habilitado a representar um espetáculo edificante quando se entrega a tal prática" (Burton 1976: 2591 .

Condenados pelas regras de boas maneiras européias, mas tolerados pelos portugueses, os palitos volta e meia apareciam na crônica machadiana, ora nas mãos de uma moça que com eles brincava ao final de uma refeição ${ }^{2 l a,}$ ora na boca de um rapaz, "sinal de que almoçara" ${ }^{21 b}$, ou com uma criança que os utilizava ruidosamente $21 c$, mostrando o desprezo das classes médias, em sua vida cotidiana, pelas regras mais severas de etiqueta.

A prática de surripiar excedentes era, ao que parece, um costume freqüente e antigo no Brasil. No jornal Periódico dos Pobres, de 1/2/1853, um conto moralista - O frango e o trombone - relatava o episódio do furto de um galináceo que sobrara à mesa, por um dos convivas de uma ceia de aniversário, com a evidente finalidade de comê-lo depois em casa. Em 10/09/1855, um novo alerta era feito aos que freqüentavam bailes, para que não enchessem o chapéu de doces, nem "arranjassem farnel".

Quanto aos almoços, aqui, tal como na Europa, eram refeições informais e em geral frugais. Dicionários de época assim definem o termo: "comida com que se quebra o jejum antes do jantar" 22a , "comer pela manhã, antes do jantar"22b, "alimento que se toma pela manhã, coisa fácil e breve"22c, "refeição da manhã que se toma ao levantar da cama"22d.

Costumavam ser servidos logo após o café da manhã, que era normalmente parco, não raro apenas uma xícara de café forte ao despertar ${ }^{22 e}$, eventualmente acompanhada de leite e pão com manteiga. Nos segmentos mais abastados o curto intervalo de tempo entre um e outro era em geral ocupado pela leitura dos jornais ${ }^{22 t}$. Era muito freqüente homens solteiros ou viúvos receberem a visita inesperada de amigos, que se convidavam para almoçar ou simplesmente aproveitar esse tempo para uma conversa necessária, sem contudo participar da mesa ${ }^{22 g}$.
20. Para a questão da $i-$ deologia de higienização no século XIX, ver Andrade Lima 1994 e 1996.

21. Extraído de Machado de Assis: 21a. Histórias românticas (1944e: 429); 21b. Relíquias de Casa Velba II (1944j: 130); 21c. Histórias da meia noite (1942: 113).

22. Extraído de: 22 a. Moraes Silva (1789 e 1858); 22b. Silva Pinto (1832); 22c.Diccionario da Lin goa Portugueza (1793); Eduardo Faria (1850 e 1859); d'Almeida \& Lacerda (1862); 22d. Domingos Vieira, 1871; 22e. Revista Popular (1860: 46); Jornal das Familias (1863: 66); Kidder \& Fletcher (1941:191); de Machado de Assis: 22f. Quincas Borba (1946c: 112) e Helena (1946a: 182); 22g. Quincas Borba (1946c: 200), Memorial de Ayres (1944c: 184) $\mathrm{e}$ Ressurreição (1944a: 12 e 181). 
23. Extraido de Machado de Assis: 23a. Papéis Avulsos (1944f: 167), A mão e a luva (1944b: 53), Helena (1946a: '77) e Ressurreição (1944a: 179); e de José de Alencar: Senbora (1995a: 118); A pata da gazela (1995b: 78), Luciola (1995c: 121) e Sonbos d'ouro (1959a: 754); 23b. Histórias da Meia Noite (1942: 92), Histórias Românticas (1944e: 258 e 427-28); c de José de Alencar: Senbora (1995a: 206), A Viuvinba (1959c: 290), Fragmentos (1959d: 1331). De Machado de Assis: 23c. Memorial de Ayres (1944c: 277), Histórias Românticas (1944e: 258); 23d. Helena (1946a: 30), Contos Fluminenses I (1944d: 291).

24. Extraído de: $24 a$. Histórias sem data (1944g: 107); e de José deAlencar:Sonbos d'ouro (1959a: 935); Ebel (1972: 69 e 98); 24b. Machado de Assis: Contos fluminenses I (1944d: 166); Histórias românticas (1944́e: 101). De José de Alencar: Sonbos d'ouro (1959a:918), Joaquim Manuel de Macedo: A luneta mágica (1990: 124). 24c. Machado de Assis: Histórias românticas $(1944 \mathrm{e}$ : 249); 24d. Machado de Assis: Histórias românticas (1944e: 101); José de Alencar: Senbora (1995a: 126, 207); Jornal das Familias (1863: 106; 1867: 111); José de Alencar: Cinco minutos (1959b: 194); 24e. Machado de Assis: Reliquias de Casa Velba I
Os horários das refeições e das rotinas diárias eram muito diferentes dos atuais. Em 1/6/1837 o Correio das Damas reportava que as gerações mais antigas comiam quatro vezes ao dia, como se segue: almoço, às oito horas; jantar, ao meio dia; merenda, às três da tarde e ceia, às sete ou oito da noite. As refeições compartimentavam o tempo, atuando como marcadores cronológicos na organização da vida cotidiana. Ao longo do século, entretanto, esses horários foram se tornando progressivamente mais tardios, de tal forma que em seus meados a hora regular do almoço era em torno das de ${ }^{23 a}$. Dependendo da ocupação exercida, no entanto, ela podia ser antecipada para as oito - em se tratando de funcionários públicos - ou nove ${ }^{23 b}$, e, no caso dos ociosos, postergada para as onze ${ }^{23 c}$. Não raro as classes dominantes, por levantarem-se tarde da cama, iam diretamente para a mesa de almoço, sem tomar café ${ }^{23 d}$.

Já o horário do jantar variava bastante, entre quatorze ${ }^{24 a}$, quinze ${ }^{24 b}$, dezesseis ${ }^{24 c}$, dezessete ${ }^{24 d}$ e dezoito horas ${ }^{24}$. As velas de sebo ou espermacete, os lampiōes de óleo de mamona, de peixe ou baleia clareavam muito pouco e a falta de luz suficiente, à noite, inviabilizava o serviço doméstico, de modo que ele precisava ser feito enquanto houvesse claridade natural. No entanto, à medida que foram se aperfeiçoando as estratégias de iluminação do interior das residências, na segunda metade do século, sobretudo a partir da introdução dos lampiões de mecha circular que produziam chama muito viva e da iluminação a gás, novas

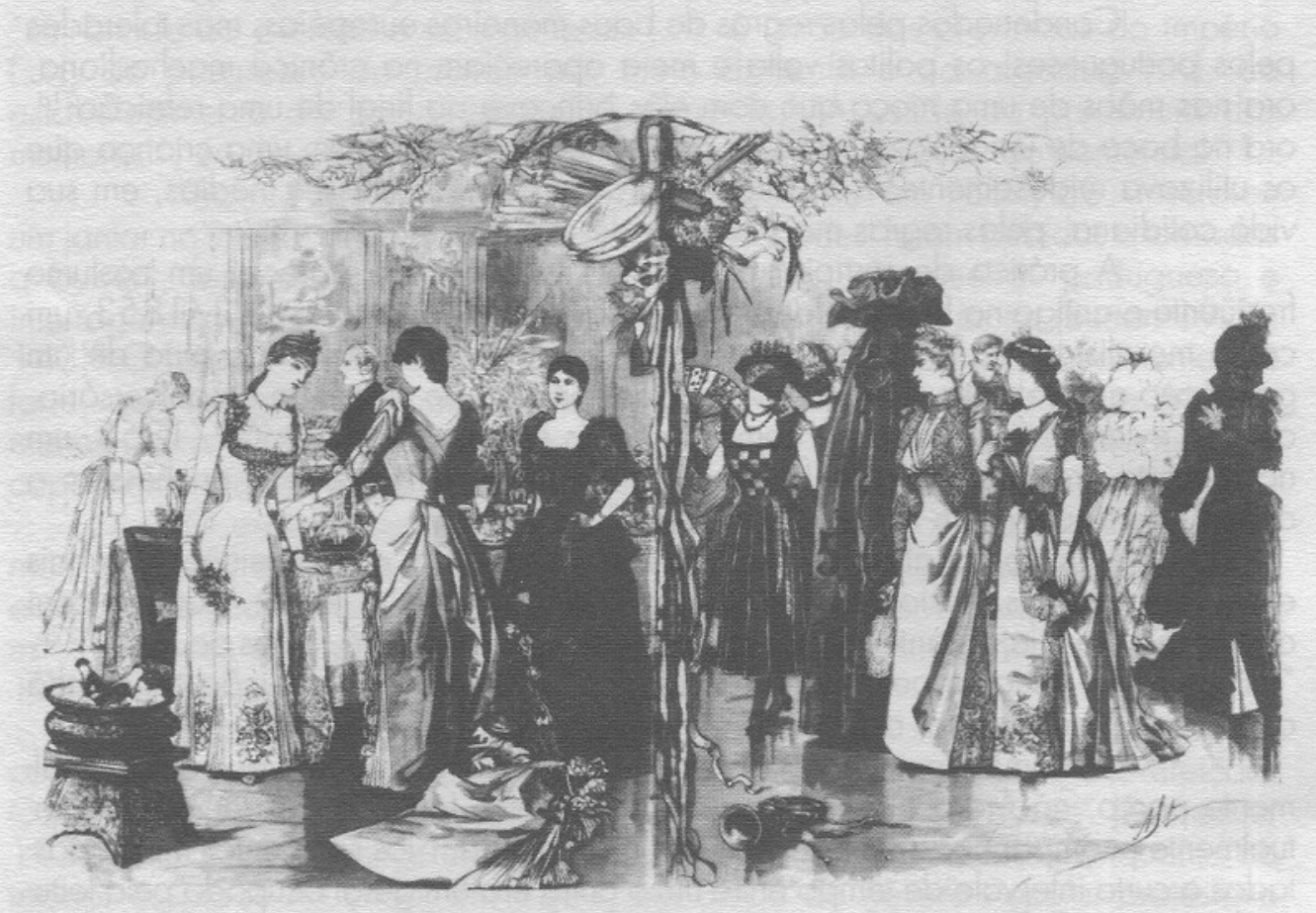

Prancha 3: Figurino do jornal A Estação, de 28 de fevereiro de 1890, com sugestões de modelos femininos. Em um baile de máscaras, vê-se ao fundo a mesa posta para a ceia festiva. 
possibilidades de interação social se ofereceram, incrementando "reuniões noturnas, saraus e tertúlias" (Lemos 1989: 44-5). Os horários se modificaram, tornando-se progressivamente mais e mais tardios, até a chegada triunfal da energia elétrica nas casas particulares, na virada do século, quando o jantar finalmente foi para o horário noturno. O café da manhã passou a ser de fato a primeira refeição, feita ao despertar. Entre meio-dia e duas horas, o almoço. Por influência inglesa, o luncheon, aportuguesado para lanche, substituiu a antiga merenda, no meio da tarde. Com o jantar transferido para as primeiras horas da noite, configurou-se aparentemente um conjunto de mudanças, que na verdade não passou de uma troca de nomes, como bem observou Burnett (1989: 68). O que era chamado jantar, tornou-se almoço; o almoço, café da manhã; e a ceia, jantar.

\section{Comidas e mais comidas}

"Each meal is a structured social event which structures others in each own image".

Mary Douglas, em Deciphering a meal (1971: 69)

Em Arte de cozinhar, de autoria de Domingos Rodrigues, mestre de cozinha da corte portuguesa, editado em 1794, há várias sugestões de menus para jantares, para cada mês do ano. Diagramas publicados ao final do livro, transcritos literalmente nas pranchas 4 e 5 , mostram a estrutura dessas refeições e sua disposição à mesa, ao final do século XVIII. Este deve ter sido certamente o modelo transplantado para o Brasil, poucos anos depois, com a vinda da corte de D. João VI.

Este mesmo modelo - e os diagramas da Arte de cozinhar claramente o ilustram - aparece repetido em Escola de Política ou Tratado prático de civilidade portuguesa, que ensinava, nas primeiras décadas do século, "como ordinariamente se dispõe a primeira coberta, se são poucos os convidados. Bem no meio da mesa se coloca a terrina com sopa, a um dos lado desta o prato com a vaca cozida, da outra um grande pedaço de presunto (outros põem arroz), pelo resto da mesa se vão pondo as mais iguarias cozidas, afogadas, estufadas, empanadas, fricandós, tudo em proporção e simetria, tantos pratos de uma parte como da outra, servindo a terrina da sopa como de centro a toda coberta (tal como na prancha 4al. Porém se forem muitos os convidados, se pode fazer v.g deste modo: no meio da mesa um presunto cozido inteiro sem couro: aos terços da mesa as terrinas de sopa; dos vãos das terrinas ao prato do meio a vaca cozida e o peito de vaca de mostarda; e havendo cabeça de vitela de mostarda se porá em lugar do peito, e por fora destes, em diferente carreira, se põe o arroz em pratos mais pequenos, o macarrão, rabioli, talharim, verduras, paios, chouriços, pés de porco, cabeças de porco, e semelhantes cousas cozidas ou ainda guisadas, mas nunca assadas, que pertencem à segunda coberta $(. . .)^{\prime \prime}$.

"Acabando-se de comer, o que pertence a esta coberta se tira e se vai servindo a segunda, estando todos assentados. No meio da mesa se põe a methor peça que houver de assado, como v.g. um peru, uma perna de vitela, um leitão, etc. Aos lados duas saladeiras com salada, e assim se vai cobrindo a mesa de tudo o que é assado, galinhas, rolas, pombos, perdizes, lombo, etc., e vários entremeios que um bom cozinheiro sabe fazer e que pertencem a esta cobertura" (tal como na prancha $4 \mathrm{~b}$ ). (1944j: 358 e 228); Histórias sem data (1944g: 107); Papéis avulsos (1944f: 155); José de Alencar: Luciola (1995c: 52). 

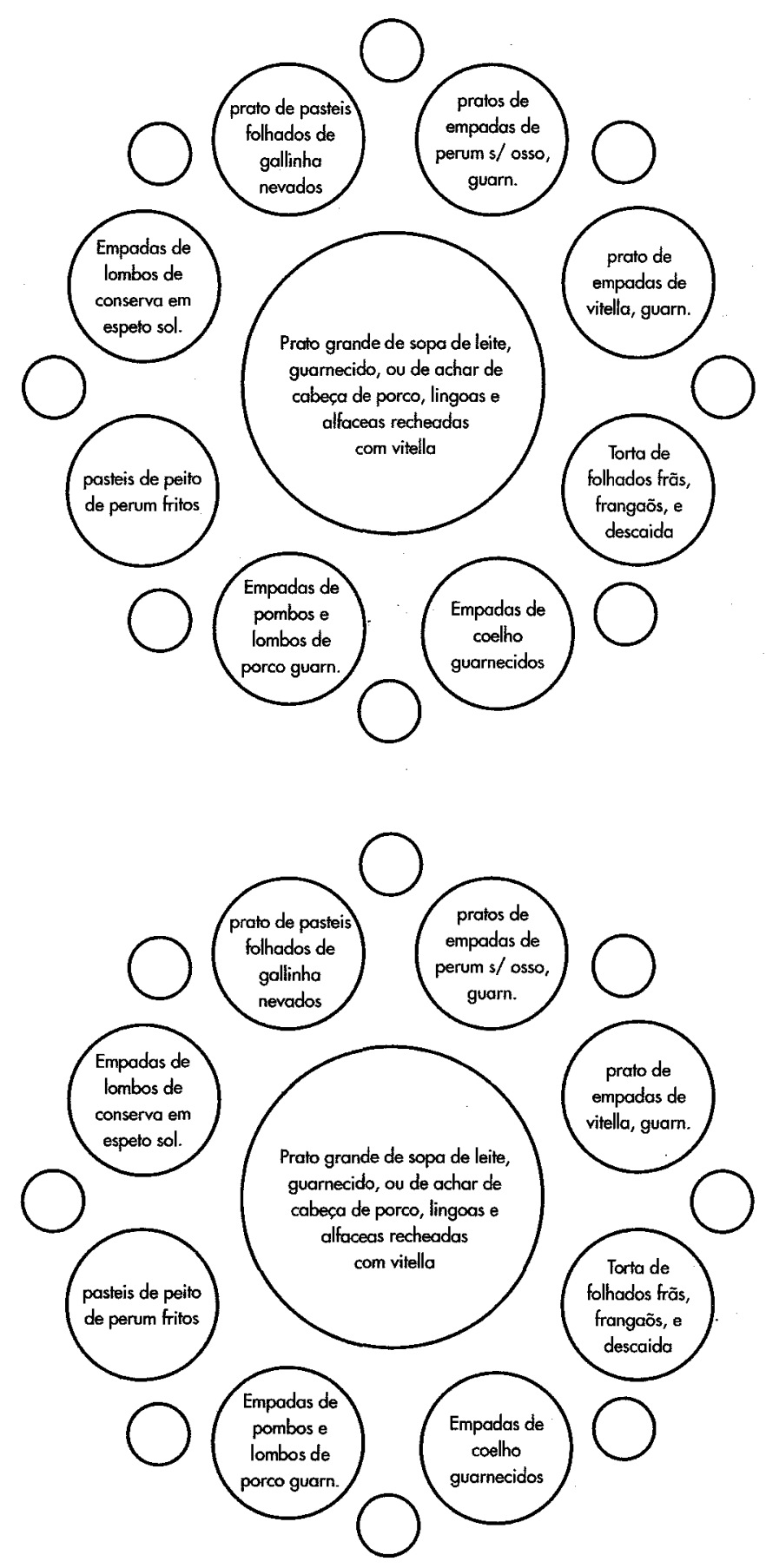

Prancha 4: Seqüência de cobertas de uma refeição portuguesa do final do século XVIII (transcrito literalmente de Arte de cozinhar, 1794) 

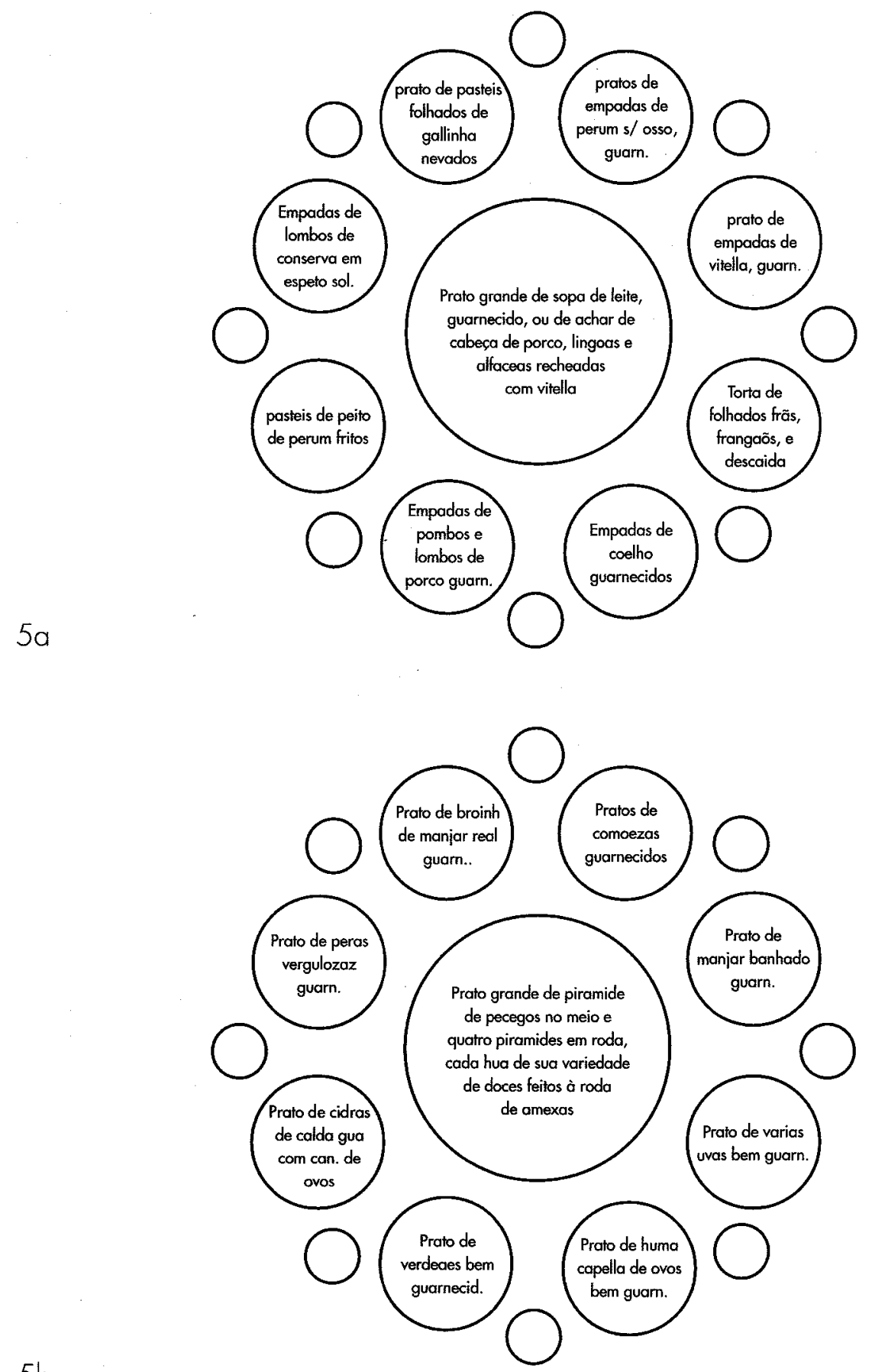

Prancha 5: Continuação da seqüência anterior. 5a: coberta de massas. 5b: sobremesas 
25. O mesmo tipo de disposição aparece em The Frugal Housewife, em 1802, o que confirma a ampla utilização desse modelo a essa época. Reproduzido em Wall (1994:118).
"Tiradas as iguarias e talheres e ministradas outras limpas e mais pequenas e as próprias do dessert, se prepara deste modo: no meio um prato grande de doce que faça cogulo e que sobressaia, ou uma corbelha de frutas, e à roda desta, ou em fileiras com exata simetria vai se pondo o doce seco, o de calda, compota, cremes, frutas e queijos (tal como na prancha 5b). Já hoje se praticam ter o dessert em outra sala, própria, soberbamente disposta".

"No fim se dá café. Não querendo mais se volta para baixo, ou se deita a colher dentro, ou ainda atravessada na boca; mas assim tem muitas vezes o perigo de esta cair".

"Nas ceias, em lugar das terrinas se pode pôr v.g um grande empanado e pode ficar a ambas as cobertas" 25 .

Não foi esta, entretanto, a composição do jantar oferecido por um diácono baiano, homem rico e erudito, ao capelão de um navio de guerra inglês e aos oficiais de sua guarnição, em 1808, que, de acordo com o relato de um dos convivas, foi a seguinte:

$1^{\underline{a}}$ coberta: às cabeceiras da mesa, duas terrinas com suculenta sopa de aves; em cada um dos quatro cantos, travessas com apetitosos leitões assados; no centro, dois alentados perus, ladeados de grandes pratos com carne cozida e assada (...), e abundante variedade dos mais finos legumes.

$2^{\underline{a}}$ coberta: composta por aves, caça, ragus e verduras em profusão, tudo primorosamente apresentado.

$3^{\underline{a}}$ coberta: massas, pastéis e doces de toda qualidade.

$4^{a}$ coberta: grande variedade "de quantos peixes podem ser pescados nesses mares", que pareceu esquisita ao conviva.

A sobremesa: toda sorte de frutas tropicais.

Diante dos dezessete convidados, garrafas de vinho do Porto e Madeira. Conforme o relato, "à proporção de serem mudados os serviços, punham diante de nós novas garrafas de vinho fresco" (...). "Um escravo servia a cada conviva e trocava os copos toda a vez que bebíamos; e tantas nos retiravam os pratos, quantas nos eram apresentadas bacias com água para lavarmos as mãos" (Pinho 1970: 311 .

Assim sendo, parece bem provável que o clássico modelo português tenha sofrido uma adaptação às condições e ao gosto local, gerando um novo padrão que se manteria arraigado ainda por um bom tempo, ao longo do século XIX, nos hábitos alimentares da população. Ele aparece bem delineado por Debret (1954: 138), nas primeiras décadas do século, descrito como o jantar de um homem abastado: "uma sopa de pão e caldo gordo, chamado caldo de substância, porque é feita com um enorme pedaço de carne de vaca, salsichas, tomates, toucinho, couves, imensos rabanetes brancos com suas folhas, chamados impropriamente nabos, etc., tudo bem cozido (...). Serve-se ao mesmo tempo o cozido, ou melhor, um monte de diversas espécies de carnes e legumes de gostos muito variados embora cozidos juntos, ao lado coloca-se sempre o indispensável escaldado (flor de farinha de mandioca) que se mistura com caldo de carne ou de tomates ou ainda com camarões; uma colher dessa substância farinhosa semiliquida, colocada no prato cada vez que se come um novo alimento, substitui o pão, que nessa época não era usado ao jantar. Ao lado do escaldado, e no centro da mesa, vê-se a insossa galinha com arroz, escoltada porém por um prato de verduras 
cozidas extremamente apimentado". A esse cardápio monótono, somavam-se inúmeras variedades de massas, como talharim, ravioli, lasanha, vermiceli, aletria, pevide, estrelinha, etc., ampliando um pouco o leque de possibilidades gastronômicas.

Ao longo do século o cozido manteve, em versões ampliadas ou simplificadas, mais ou menos incrementado conforme o estrato social, ao lado da galinha, uma posição de prestígio no cotidiano da mesa brasileira. Viajando pelos arredores do Rio de Janeiro, em 1819, von Leithold descreveu um jantar que "constava de uma substanciosa sopa de galinha, de ovo com espinafre, de um fricassê de galinha com molho de pimenta nativa muito forte (...) e um cozido de carneiro com salada; por fim, de laranjas e biscoitos como sobremesa." (Leithold \& Rango 1966: 811. Quase meio século depois, em um conto publicado no Bazar Volante, em 1866/67, o menu de um passeio a Paquetá ainda incluía a ambos, como pratos principais, além de pato e arroz de forno.

Em As bodas do Dr. Duarte, Machado de Assis forneceu claramente a seqüência das cobertas adotadas à época, ao narrar um banquete de casamento: "Sentaram-se na ordem usual. Durante alguns minutos houve aquele silêncio que precede as batalhas, sendo esta alegoria perfeita, que até o tinir das espadas era ali imitado pelo ruído das colheres nos pratos. $O$ exército atacou resolutamente a sopa; fez depois um reconhecimento dos ensopados; avançou para o esquadrão dos guisados, tomou à viva força o baluarte de um perú, e só depois dessas grandes proezas é que se travou geral conversa" 26 .

Um dos fatores que provavelmente contribuíram para dificultar a adoção plena do modelo europeu, fortemente baseado no consumo de carne, foi a má qualidade de bovinos e ovinos no Rio de Janeiro. Sem pastagens extensas, a região era abastecida com a produção de outras áreas, como Minas Gerais, Goiás, Mato Grosso, São Paulo e Rio Grande do Sul (Lobo 1978: 167; ver Saint-Hilaire 1975: 52; Graham 1990: 196; Pohl 1951: 151; Walsh 1985: 213-4; Luccock 1975: 29-33; Burmeister 1952: 951.

$\bigcirc$ gado, após longas e extenuantes viagens, chegava ao seu destino no limite do depauperamento, exausto, magro, em péssimas condições para o abate. A impropriedade dessa carne permitia sua utilização apenas em caldos e cozidos. Como alternativas restavam a galinha, privilégio das camadas superiores e dos enfermos, e o porco, "o alimento mais usado pelo povo", ao lado do feijão com toucinho, da carne seca, da farinha de mandioca e da imensa variedade de frutas. Os peixes costumavam ser evitados, por apodrecerem com facilidade, além de serem considerados transmissores de doenças, como o escorbuto e a lepra (Luccock 1975: 31 ). Nas ocasiões festivas, no entanto, não faltavam à mesa, como indefectiveis peças de resistência, o peru e o clássico leitão, "uma espécie de autoridade simbólica"27.

A doçaria, herança da cozinha portuguesa, tinha um importante papel na mesa carioca, onde pontificavam fios d'ovos, toucinhos do céu, pés-de-moleque, cabelos de anjo, baba-de-moça, fatias celestes, viúvas, mães-bentas, suspiros, rosários, entre outros. $\bigcirc$ Convento da Ajuda era famoso pela excepcional qualidade dos doces que produzia. Definida por Gilberto Freire (1939: 24-6) como uma verdadeira maçonaria, suas receitas eram cuidadosamente guardadas em segredo pelas famílias.
26. Conto publicado no Jornal das Famílias (1873: 180). O trecho aqui transcrito foi suprimido da versão que apareceu posteriormente na coletânea Histórias da Meia Notte, editada por W. M. Jackson editores, em 19 \{́.

27. Assim definido por Paulina Philadelphia, cronista do fornal das Familias, em 1864; Jornal das Senboras (13/2/ 1853); Machado deAssis, Contos Fluminenses II (1944d: 308-10); Histórias da meia noite (1942: 92) 
28. André Guillot, $L a$ grande cuisine bour geoise; Escoffier, o grande embaixador da cozinha francesa no último quartel do século XIX e primeiro chef condecorado com a Légion d"Honneur: ver $M a$ cuisine (1988), destinado às donas de casa.
Todo o processo de ritualização do jantar intensificou evidentemente o interesse pela culinária e, mais ainda, pela gastronomia. Por volta de meados do século, acompanhando a explosão de manuais de boas maneiras, surgiram aos borbotões novos livros de receitas, em especial na França e na Inglaterra, em grande parte destinados às camadas médias ou, mais especificamente, à "cozinha burguesa". As tiragens esgotavam-se poucas semanas após a sua impressão, novas edições eram rapidamente providenciadas e em curtos intervalos de tempo dezenas de milhares de volumes eram vendidos. Em 1849, o Modern Housewife or Menagère, de Alexis Soyer, com centenas de receitas, esgotou-se duas semanas após o seu lançamento, exigindo novas edições. Em 1851, contabilizava 21.000 volumes vendidos. Muitos dos grandes compêndios de culinária, clássicos da haute cuisine francesa, ganharam versões simplificadas - a chamada cuisine bourgeoise-acessiveis à dona-de-casa mediana, ávida por colocar à sua mesa o que antes era exclusivo das camadas superiores ${ }^{28}$.

No Rio, vários periódicos passaram a incorporar seções voltadas para interesses femininos, onde receitas apareciam regularmente. O Jornal das Famílias, que substituiu em 1863 a sisuda Revista Popular, impresso em Paris e sob forte influência francesa, foi concebido para esse público (Mauro 1991: 222-9). Em meio a seções de moda, medicina popular, conselhos, mexericos, trabalhos manuais, romances e novelas, chegou a ter uma coluna assinada, exclusivamente dedicada à economia doméstica. Sua redatora, Paulina Philadelphia, entre outras sugestões e ensinamentos, publicava receitas culinárias para o dia-a-dia das donasde-casa. Tendo em vista a considerável penetração desse jornal entre as classes médias e altas, o que aí se difundia decerto figurou no cardápio cotidiano das familias cariocas.

Entre 1863 e 1878, multiplicaram-se sucessivamente nesse espaço receitas de sopas, guisados, cozidos, fricassés, fritadas, bifesteques, costeletas, salames, salsichas, miúdos de boi, porco, carneiro (fígado, rim, língua, miolos, tripas, bofe, mocotól, frangos em diversas modalidades, ostras e mariscos, almôndegas, ovos, massas (talharim, ravióli), bolinhos, legumes e tubérculos (cenoura, abóbora, aspargos, batata), verduras (repolho, espinafre, chicórea, alface, acelga, couve, couve-flor), arroz, feiiōes, lentilhas, ervilhas. Entre os doces, figuravam sonhos, bolos, gelatinas, compotas, doces de frutas e cremes. Os periódicos O Sexo Feminino (1875), Primavera (1880), O Sorriso (1881), Archivo das Famílias (1881) e A Família (1 888 a 1894) incorporavam por seu lado uma variedade maior de doces, sugerindo folhados, broinhas, marmeladas, delícias, galanteios e pudins. Estes últimos, atestando a força da penetração dos ingleses, começaram a aparecer mais intensamente nas décadas finais do século, ao lado de rosbifes (roast beef) e bifesteques (beef steak), o mesmo ocorrendo com as batatas fritas (Machado de Assis 1944j: 330). Empadas e pastéis foram muito apreciados ao longo de todo o século, a julgar pelas inúmeras e constantes referências nas fontes consultadas Uornal das Senhoras, $11 / 11 / 1851$; O Arlequim, 1867; Archivo contemporâneo illustrado, 1889; Machado de Assis, Histórias da meia noite, 1942: 107; José de Alencar, Senhora, 1995a: 1201.

Como temperos, a noz moscada ralada era amplamente utilizada em grande parte dos pratos, além do vinagre, pimenta do reino, alho, cebola, salsa e cebolinha, cravos da índia (em caldos e pratos salgados), alcaparras, e, em 
menor quantidade, segurelha, louro e alecrim. Como gordura, empregava-se a manteiga, o azeite doce e a banha de porco. A farinha de trigo era sempre colocada em molhos, o sumo de limões era adicionado tanto sobre comidas salgadas quanto doces, e nesses últimos empregava-se com freqüência a flor de laranja. Embora muitos desses pratos façam parte até hoje da mesa brasileira, seu sabor sem dúvida alguma era diferente, sobretudo em virtude do emprego maciço da noz moscada, pouco utilizada atualmente.

As rotinas de preparo dessas comidas na cozinha tinham como suporte - grande fogão de lenha com suas panelas de ferro, tachos de cobre e vasilhas de barro, que aparecem com grande freqüência nos sítios arqueológicos. Tabuleiros de folha, ferros de bife, paus de abrir massa (rolos), peneiras de palha ou crina, coadores de pano, pilöes de pedra ou madeira com suas respectivas mãos, frascos de vidro vedados com rolhas, etc., eram os implementos que figuravam nas receitas publicadas nos jornais, necessários ao seu processamento. As peças de ferro e cobre eram em geral importadas ${ }^{29}$, enquanto as demais eram de fabricação local ou mesmo doméstica. A falta de équipamentos mais eficazes, como panelas de pressão, eram desenvolvidas estratégias como colocar fortes pesos sobre a tampa das caçarolas para concentrar o vapor ou então "barreálas" à toda volta com massa de farinha de trigo para vedá-las hermeticamente.

Essas receitas para o cotidiano estavam fortemente fundadas na culinária portuguesa e local, com leves toques italianos, franceses e ingleses. As tentativas de se anglicizar cada vez mais a mesa brasileira se intensificavam, como bem demonstrou em 1872 o periódico $A$ Luz, com o seguinte comentário: "É fora de dúvida que o costume de cozer a carne para fazer sopa vai acabando, mudando-se esse hábito, que é muito português, pelos estilos ingleses". Essa verdadeira babel culinária já era reconhecida à época, como se vê no trecho de um conto de A.E. Zaluar, publicado no Jornal das Famílias, em 1866: "ao fundo substancial e apetitoso da cozinha brasileira juntava-se um sabor da culinária francesa que daria as honras de sibarita a um lord inglês" ...

Os jantares festivos, no entanto, seguiam à risca o estilo francês. Dos menus das reuniões oferecidas regularmente, aos sábados, pelo casal Manuel Maria Bregaro, por exemplo, aos seus amigos na esplêndida residência do Andaraí, em meados do século, ao menu do Baile da llha Fiscal (Pinho 1970: 160 e 334), a França era o grande modelo. Dizia $O$ mentor das brasileiras, em 1829: "Neste pais a moda vem da França e portanto não temos destas guias da moda, destas governadoras de bom tom, que nas outras cortes dão leis à sociedade".

Desta forma, dois modelos de alimentação foram simultaneamente adotados pelos cariocas, no século passado, em domínios opostos. Na esfera privada, a mesa familiar, íntima, cotidiana e farta, bastante conservadora, mantinha na sua base a tradição dos colonizadores, não obstante a incorporação de outros elementos, com intensidade variável. Na pública, entretanto, a mesa formal, cerimoniosa, renegava as origens e adotava a sofisticada culinária francesa.
29. Para uma ampla ilustração do equipamento de cozinha do século XIX, ver Marshall (1976); Norwak (1977); Arminjon \& Blondel (1984). 
Louças e mais louças

"In order to prolong the time, and to enjoy the gentlemen's society as much as possible, I do not have the dessert placed on the table until ten or twenty minutes after the clothe is removed; this gives an opportunity to my guests to admire the beautiful Sèvres dessert plates, containing views of different French chateaux; this, of course, gives a subject of conversation to those who have visited them".

Alexis Soyer, 1853 (apud Visser 1992: 271)

A intensificação do processo de industrialização e a conseqüente massificação no fabrico de bens de diversas naturezas jogou no mercado uma ampla variedade de novos produtos. Artigos de luxo, até então exclusivos das classes superiores, ganharam simulacros produzidos a custo muito inferior, o que permitiu uma extraordinária difusão desses bens entre os segmentos menos privilegiados, ansiosos por adquiri-los, provocando uma verdadeira explosão de consumo.

Uma das categorias de objetos mais representativas deste processo foi a das louças de mesa, que acabaram se transformando em um dos principais setores da indústria européia. No século XVIII, a fascinação da realeza européia com as porcelanas fez com que fossem implantadas diversas manufaturas, a serviço das principais casas reais: Meissen, na Saxônia (1709), Viena (1718), Höchst (1720), Vincennes (1740), Capo di Monte, Nápoles (1743), Fürstenberg (1744), Berlim (1750). Frankenthal (1755), Sèvres (1756), Nymphenburg, Ludwigoburg (1758), Copenhagen (1772). Como exemplo, a fábrica de Meissen cresceu na seguinte proporção: 26 operários, em 1719; 49, em 1730; 218, em 1740; 337, em 1745 e 378, em 1750. Em Berlim, a manufatura chegou a absorver cerca de 400 operários (Sombart 1983: 169-70). Trabalhando a todo vapor para atender às excentricidades da nobreza, às encomendas de milhares e milhares de peças destinadas a saciar a paixão de reis e príncipes pelas porcelanas, essas manufaturas já estavam solidamente estabelecidas em meados do século.

Um surto de proporções inimagináveis para nós, atualmente, como bem disse McKendrick 11982: 1001, tomou conta das sociedades européias, por volta de 1750. O fascínio que as porcelanas despertavam nas classes altas e médias gerava um desejo ardente de possuílas, provocando uma efetiva epidemia, classificada na literatura como china mania, ou seja, uma verdadeira obsessão por louças (McKendrick 1982: 100; Blaszczyk 1994: 126). O prestígio aristocrático que conferiam, a ponto do Duque de Württemberg ter afirmado serem elas "um acompanhamento indispensável do esplendor e da magnificência" (McKendrick 1982: 101), produzia uma ansiedade histérica de consumo, que levava as manufaturas a trabalhar freneticamente para atender às encomendas de milhares e milhares de peças, por parte da nobreza. Os altos custos dessas excentricidades, entretanto, geravam perdas consideráveis, fazendo com que os fabricantes enfrentassem sérias dificuldades financeiras. Subsídios reais procuravam reparar esses prejuízos, com os monarcas patrocinando abertamente a produção e apondo sua chancela aos produtos, como fez luiz XV, em Sèvres.

Na Inglaterra, nenhum rei ou rainha chegou a fundar de fato um desses estabelecimentos. Por volta de 1730, a região de Staffordshire labrangendo Hanley, Burslem, Tunstall, Longport, Longton, Fenton, Cobridge, Lane End e Stokel, já possuía diversas manufaturas, porém com produção voltada sobretudo para o abastecimento 
local e poucas vendas para outros mercados (ver Godden 1964: 15). No entanto, um desses louceiros, Josiah Wedgwood, com extraordinário tino comercial e rara sagacidade, concebeu uma das mais brilhantes estratégias da história do consumo, conseguindo revolucionar as técnicas comerciais do seu tempo e colocando em pouco tempo Staffordshire-e, mais ainda, a Inglaterra- na liderança da produção mundial de louças.

Percebendo que a conduta da aristocracia era invariavelmente copiada pelas outras classes e que a moda se difundia de forma muito rápida para baixo, vislumbrou um amplo mercado em expansão, pronto para ser conquistado. Mantendo sempre a alta qualidade dos seus produtos, a supremacia técnica sobre os concorrentes e recusando-se a diminuir preços para competir com eles, Wedgwood obteve a preferência da aristocracia, tornando-se a manufatura da rainha. Aproveitando uma conjunção favorável de fatores, como a melhoria das estradas, o aumento da renda, a expansão do comércio transoceânico e das exportações para as colônias, entre outros, abriu a produção de sua manufatura - e, por extensão, a de seus concorrentes de Staffordshire - para o mundo, tornando-se internacionalmente conhecido.

- Essa difusão foi de tal ordem que, no limiar do século XIX, B. Faujas de SaintFont fazia o seguinte comentário sobre as louças inglesas, a propósito de sua viagem à Inglaterra, Escócia e às lthas Hébridas: "Its excellent workmanship, its solidity, the advantage which it possesses of sustaining the action of fire, its fine glaze, impenetrable to acids, the beauty and convenience of its form, and the cheapness of its price, have given rise to a commerce so active and so universal that in travelling from Paris to Petersburg, from Amsterdam to the furthest part of Sweden, and from Dunkirk to the extremity of the South of France, one is served at every inn with English ware. Spain, Portugal and Italy are supplied, and vessels are loaded with it for the East and West Indies and the continent of America" lapud Miller 1980: 14; McKendrick 1982: 137).

Responsável por uma série de invenções revolucionárias, como a creamware-designada como Queen's Ware - uma faiança de cor clara e preço acessivel que substituiu, na segunda metade do século XVIII, o estanho até então dominante nos utensílios de mesa, e que teve uma extraordinária penetração; o green glaze, o black basalt ou egyptian black e posteriormente a pearlware; utilizando recursos como políticas agressivas de vendagem; acreditando no poder de venda dos nomes de poderosos e influentes que batizavam suas louças; angariando a aprovação de artistas, arquitetos e connoisseurs, conseguiu monopolizar os segmentos mais altos da sociedade. Seus produtos estavam em todas as casas reais da Europa. Comprados por reis, tornavam-se alvo da cobiça da aristocracia, da pequena nobreza e assim por diante, descendo progressivamente na escala social até chegar às camadas médias.

Para suprir a extraordinária demanda desses estratos mais baixos era fundamental baratear os custos, e a faiança fina - particularmente a pearlware pelas qualidades descritas por SaintFont, tornou-se, ao longo da década de 1780, o sucedâneo por excelência da porcelana, viabilizando a produção em massa. Em carta a seu sócio Bentley, Wedgwood admitiu ostensivamente a intenção de fazer da pearlware uma imitação mais barata daquele material. Alguns fatores contribuíram favoravelmente para isso: a obtenção, na justiça, do direito de uso 
30. Para uma descrição em detalhe desse processo, ver Coysh \& Henrywood (1995: 8)

31. Para maiores detathes sobre esta técnica, ver Williams (1.981) das argilas brancas de Cornwall, até então autorizadas apenas para a fabricação das louças translúcidas, somada à saturação do mercado pela creamware e às medidas protecionistas limitando a importação de porcelanas chinesas, permitiram a produção em massa do novo produto e a expansão vertiginosa das manufaturas inglesas. Com uma pasta mais fina e mais clara, a pearlware tomou definitivamente - lugar da creamware, no início do século XIX.

Com preço reduzido, essas faianças popularizaram-se enormemente, penetraram nos segmentos médios da sociedade, invadiram todas as casas, promovendo uma fantástica transformação visual nos seus interiores, graças ao incremento notável dos seus padrões decorativos. O aprimoramento das técnicas e a introdução do decalque (transfer printing) permitiram uma multiplicidade de novas expressões, de grande efeito estético, fazendo com que a febre por porcelanas da aristocracia setecentista contagiasse com igual intensidade as classes médias, só que por um material análogo, substitutivo e condizente com suas posses.

Nas últimas décadas do século XVIII, começou a ser fabricada em grande quantidade a faiança fina com decalques em azul. Os estabelecimentos ceramistas de Staffordshire e também de Yorkshire, Lancashire, Northumberland e sul de Gales produziram milhares de padrões, com uma temática muito diversificada. Essa decoração, que tomava todo o campo visual do prato, deixava em segundo plano o que a rigor deveria ser a essência da refeição, ou seja, os alimentos servidos. De início, entre 17.80 e 1800, inspiraram-se na porcelana chinesa de exportação (chinoiserie), sem dúvida alguma para conseguir penetração em um mercado até entõo dominado por ela. Nos quinze anos que se sucederam, tomaram como fonte de inspiração livros com vistas da ltália, Ásia Menor e Índia, bem como livros de botânica, de cujas estampas extraíam modelos para composições florais. Paisagens, castelos e abadias famosas, cenas campestres, multiplicavam-se na superficie dos pratos, bem ao gosto romântico da época (ver Dyson 1982: 376-7).

Entre 1815 e 1835, a instalação do culto ao pitoresco fez com que os louceiros recorressem a livros de viagens. Motivos reservados no interior de medalhões, associados a formas geométricas e vegetais, eram aplicados à bordas de pratos, travessas, sopeiras, etc., compondo séries que funcionavam como uma espécie de marca registrada do fabricante.

Nos dez anos que se seguiram, o azul perdeu a exclusividade e outros tons passaram a ser utilizados no processo de decalque ${ }^{30}$ : preto, marrom, verde, rosa, sépia, azul claro, púrpura. A técnica do borrão ${ }^{31}$ tornou-se extremamente popular, sobretudo para exportação. $O$ nome do padrão decorativo aparecia em geral no verso, no interior de cartuchos com folhas e flores.

Em 1842, entretanto, a Copyright Act determinou a proteção de desenhos originais, um golpe de morte na pirataria intensamente praticada pelas manufaturas. Como recurso alternativo, elas passaram a produzir cenas imaginárias que recebiam nomes de cidades, rios, etc., com os quais nada tinham em comum. Lagos, pagodes, mesquitas, castelos, árvores, fontes, balcões, vasos, montanhas à distância, grupos de pessoas, cães, eram os elementos normalmente utilizados nessas composições.

Na segunda metade do século, no entanto, a completa saturação do mercado pela faiança fina decalcada determinov o declínio da produção, surgindo em seu lugar a sua antítese: a preferência pelos serviços brancos, eventualmente 
com discretos relevos ou filetes nas bordas. A decoração excessiva foi reduzida, tornando-se apenas uma moldura para os alimentos. Em 1877, o manual Le savoir vivre (Alq 1877: 86) considerava de "menos bom gosto e menos adequados" os serviços com desenhos e a cores, recomendando o branco, por parecer "mais asseado e estimulante". Idealmente deveria ser utilizada a porcelana com filetes dourados e monograma no meio, tão elegante quanto "a bela porcelana da China, que não agrada a todo mundo". A essa época, as faianças azuis saíram de cena, sendo consideradas adequadas apenas para o campo.

Poucos anos depois, no Brasil, o comércio local já acompanhava essa tendência, conforme o reclame de louças da Casa Moreira publicado no jornal $O$ Fluminense (24/05/1883), onde era anunciado um "completo sortimento de aparelhos (...), em louça ou porcelana com ouro ou sem ouro". A Casa Moniz, estabelecimento especializado situado à rua dos Ourives, anunciava no Almanak Laemmert, no ano seguinte (1884: 1974 e 2083), junto com outras lojas do gênero, como a Uberto Wagner, a impressão de monogramas em qualquer serviço de mesa.

Esta mudança não se processou sem resistências, a julgar pelo comentário de Clarence Cook, autora de The House Beautiful, em 1878, condenando vigorosamente a louça branca, por considerátla "fria, descuidada", pouco apetitosa e insalubre, e louvando a azul e branca, de preferência antiga e oriental. Segundo ela, a louça branca "tirava o amarelo da manteiga, fazia o leite parecer azul, lançava suspeitas sobre o chá, tirava o brilho do açúcar" (Blaszczyk 1994: 128). Contudo, apesar dos opositores, a segunda metade do século assistiu de fato a uma mudança de gosto e as tabelas de preço da época a confirmam. A partir de 1850, as louças brancas que até então eram as mais baratas, encareceram consideravelmente, passando a custar o mesmo que as decalcadas em formas e dimensões semelhantes.

Entre 1850 e 1870, a ironstone branca ganhou os mercados e tornou-se extremamente popular, com formas muito diversificadas, tendo sido exportada em quantidades impressionantes para a América. No Brasil, um anúncio de louças publicado em A familia punha em oferta, em 07-07-1892, "canequinhas brancas para café a $5 \$$, ditas pintadas a $6 \$$ e de porcelana a $10 \$$ a dúzia", o que confirma, também no Brasil, a subida de preços da louça branca na segunda metade do século, colocada em um patamar bem próximo da pintada. A partir de 1870, a diversificação das formas diminuiu e na virada do século as encomendas foram sensivelmente reduzidas, sugerindo o esgotamento de um ciclo (Miller 1980; Wetherbee 1985).

Escavações arqueológicas conduzidas em sítios do século XIX, em todo o Brasil, trazem à luz quantidades impressionantes dessas faianças. As formas e os padrões decorativos recuperados correspondem exatamente aos tipos produzidos pelas manufaturas inglesas, descritos acima, de tal maneira que o país bem poderia ter sido incluído na enumeração de Saint-Font, encabeçando-a como um dos mercados mais receptivos aos produtos ingleses. Todas essas categorias encontram-se representadas com grande popularidade nas unidades domésticas brasileiras e, em particular, do Rio de Janeiro ${ }^{32}$.

Um elenco básico, com cerca de uma dúzia de tipos: padrão Willow (foto 1), Azul Borrão (foto 2), louça branca, simples, ou com discreta decoração
32. Observaçöes feitas a partir de amostras recuperadas em escavações intensivas nos sítios Fazenda da Mandioca, Fazenda São Fernando, Solar Grandjean de Montigny, Imperial Sociedade Amante da Instrução e thiha do Major em Angra dos Reis; em prospecções sistemáticas em fazendas doVale do Paraíba, em chácaras e solares atualmente na área urbana na cidade do Rio de Janeiro (realizadas por Andrade Lima equipe). $\mathrm{E}$ ainda, em escavações realizadas pela então Coordenadoria de Arqueologia da Secretaria do Parimônio Histórico e Artístico Nacional - Fundação Nacional pró-Memória (SPHAN/ FNpM), atual Instituto do Patrimônio Histórico e Artístico Nacional (IPHAN) nos sítios: Paço Imperial, Antigo Cais da Praça XV, Casa dos $\mathrm{Pi}$ lóes, bem como pela Fundação Brasileira para a Conservação da Natureza (FBCN), em fazendas de café na Floresta da Tijuca. 
33. Nota de rodapé do livro Viagens ao interior do Brasil, de John Mawe (1978:82-3), por Ribeiro Lessa. em relevo nas bordas, dentre os quais se destaca o padrão trigal (foto 3), padrão Shell Edge (foto 4l, louça de Macau (foto 51, decalques de padrões orientais (fotos 6,7 e 15), paisagens da ltália e da Grécia (fotos 8 e 9), cenas bucólicas (foto 10), castelos e abadias ingleses (foto 1 1) - compondo a linha romântica -, assim como os padrões Sponge, Mocha, policromo em motivos florais e ainda com faixas, listra e motivos geométricos, em múltiplas combinações e variações (fotos 13, 14, 16 a 20), se repete sistematicamente nas centenas ou milhares de cacos recuperados em cada sítio pesquisado (ver Andrade Lima 1989 e Andrade Lima et al. 19931.

A louça de Macau, designação genérica e equivocada que era dada à louça azul e branca proveniente da China e embarcada naquele entreposto, abrangia uma ampla produção, desde serviços finos até peças extremamente grosseiras e baratas, que Brancante (1981: 653) designou como "macaus de carregação". Esta louça "era baratíssima; vinha como lastro no fundo dos navios e se julgava indigna de aparecer nas mesas da aristocracia e da burguesia opulenta, sendo relegáda ao uso dos criados e dos dependentes de baixa condição social" ${ }^{\prime 3}$.

É essa produção degradada, inferior, com pasta grosseira, de tonalidade cinza-azulada, desenhos pouco elaborados e mal executados, com péssima qualidade grática e cores pouco firmes, que aparece nos sítios cariocas. Graças a um decreto de D. João VI, em 1810, isentando de imposto todas as mercadorias provenientes de Goa e Macau, elas continuaram penetrando no país ainda por um bom tempo, paralelamente à produção inglesa.

Os demais padrões, na sua quase totalidade de manufaturas inglesas laparecem com baixa freqüência louças da Société Céramique Maastricht, holandesa, e Opaque de Sarraguemines, francesa, entre outras ainda menos populares), encaixam-se na classificação feita por Miller (1980: 3-4 e 1991), particularmente válida para as louças da primeira metade do século XIX. Foram construídas quatro categorias, com base nos elementos decorativos e em listas de preços de estabelecimentos ingleses, como se segue:

- a primeira compreende as louças mais baratas, sem qualquer decoração. Aí se incluem as creamwares (foto 3 ) e os variados tipos de pasta que surgiram ao longo do século, compondo pratos, tigelas, utensílios de cozinha, urinóis. A única exceção é a ironstone, da segunda metade, mais cara que a creamware.

- a segunda compreende as louças com decoração pouco complexa, como os padrões Shell Edge, Sponge, Spatter, Dipped, Lined; Banded, Mocha. Não exigia muita habilidade do artesão; há sempre diferenças entre as peças e uma nunca é exatamente igual à outra. Dentre as louças decoradas, eram as mais baratas (fotos 4, 13, 14, 18, 19, 20).

- a terceira compreende as louças pintadas com motivos florais, padrões geométricos, paisagens chinesas estilizadas. Exigia do artesão habilidade suficiente para que, em um mesmo serviço, as peças ficassem razoavelmente semelhantes entre si. Seus preços estavam em um patamar intermediário entre a segunda e a útima categoria.

- a quarta compreende as louças decalcadas, cuja técnica permitiu a fabricação de peças exatamente iguais, com decoração bastante complexa. Na última década do século XVIII, elas custavam entre três e cinco vezes mais que a creamware. Esta diferença, no entanto, caiu para uma vez e meia a duas vezes mais, em 
meados do século XIX (fotos 8 a 12). Dentre elas, o padrão Willow era o mais barato (foto 1), enquanto os borrados eram os mais caros (foto 2).

Nos sítios arqueológicos cariocas, as louças brancas são sempre as mais numerosas e os fragmentos recuperados tanto podem pertencer a peças totalmente brancas, como a porções não decoradas de tipos como Shell Edge, em que apenas as bordas recebiam decoração. Seguem-se em popularidade as louças azuis e brancas, em diferentes padrões. As fontes consultadas, literárias e documentais, comprovam o que a arqueologia vem resgatando.

Por volta de 1820, Maria Graham (1990: 335) referiu-se a um jantar onde "tudo foi servido em baixela inglesa azul e branca. As toalhas e guardanapos eram de algodão lavrado, e havia bastante prata usada, mas não exposta". A louça inglesa começava pouco a pouco a substituir as porcelanas da China e da Índia, até então dominantes nas mesas das classes abastadas do Rio de Janeiro.

Em meados do século, Expilly descreveu uma mesa de jantar, nos seguintes termos: "O aparelho era de faiança azul, de fabricação inglesa, tão divulgada na América do Sul. Pequenos guardanapos franjados estavam colocados sobre os pratos, formando o conjunto uma mesa bem posta, (...) não faltavam copos, nem tatheres. Dois belos jarros com flores rematavam a garridice da mesa. $\bigcirc$ copeiro, de boa aparência, ocupava seu posto à direita do senhor. Duas mucamas (...) postavam-se atrás das senhoras" (Expilly 1935: 399-400). Essa extraordinária difusão da louça inglesa no Brasil também já tinha sido observada anteriormente por Langsdorff que, em sua passagem por Minas Gerais, fez o seguinte registro em seu diário, no dia 21-7-1824: "nos últimos anos, trouxeram para cá tantas faianças inglesas que, hoje, elas podem ser vistas em quase toda parte". Da mesma forma que Walsh anotou, em 1828/1829, que em um jantar foi utilizado um jarro de faiança "de Staffordshire, a qual, como várias outras manufaturas inglesas, podia ser encontrada em qualquer parte do país" (Waish 1985: 127/34.

Já na década de 70 , a ilustração de uma anedota publicada no periódico A Comédia Social, mostra a cena ńtima de um casal junto a uma mesa de jantar displicentemente arrumada, mas com a infalivel sopeira e pratos de louça branca junto à garrafa de vinho (prancha 6). Por essa mesma época, em um dos contos de Reliquias de Casa Velha (Machado de Assis 1944j: 165), personagens machadianos de classe média baixa utilizavam louça branca, decorada apenas com friso azul (um tipo que aparece também regularmente nos sítios cariocas).

Oromance Sonhos d'ouro, de José de Alencar (1959a: 7241, com ação passada em 1871, mostra a desqualificação da faiança azul e sua conseqüente absorção pela classe média baixa: "todos os domingos punha-se invariavelmente no meio da mesa uma grande manteigueira de louça azul, como era o resto do aparelho", manteiga esta que era apenas admirada e na qual não se devia tocar. "Posta no meio da mesa ela não era mais do que um símbolo, um emblema", como era também a própria louça.

Em 1889, em um artigo do periódico A Família, onde era louvada a importância do ritual da refeição para o bem estar familiar, "a base da felicidade na vida do homem", a louça branca pontificava na mesa carioca, ao final do século: "a fumacinha azulada saindo em novelos pequenos da singela sopeira de
34. WaIsh referiu-se equivocadamente à região de Staffordshire com sendo uma manufatura. 
35. No rico inventário de Maria Luisa Neves Machado, abastada moradora do aristocrático bairro carioca do Cosme Velho, em 1877, constam "um aparelho de porcelana com friso de coral", "um aparelho de porcelana dourado com friso verde", "um dito de branca para chá" (Arquivo Judiciário do Rio de Janeiro, caixa $9, \mathrm{n}^{\circ}$ 004). porcelana branca, paira no ar um aroma tentador e convidativo (...)".

O exame de alguns inventários do último quartel do século passado confirma a progressiva substituição da exuberante louça azul e branca por um estilo mais sóbrio, totalmente branco ou com decoração em frisos de cor ou dourados. Os serviços azuis e brancos começaram a aparecer nos arrolamentos como incompletos, desfalcados, enquanto os brancos eram descritos como completos, íntegros. Ao que tudo indica, a reposição de peças quebradas não era feita mais nos mesmos padrões decorativos, já fora de moda, e outros tipos mais condizentes com o novo gosto passaram a ser adquiridos ${ }^{35}$.

Anúncios publicados no Almanak Laemmert, na segunda metade do século XIX, ofereciam "aparelhos de mesa, sobremesa, chá, café e almoço" completos, mas também em "peças avulsas" (Almanak Laemmert 1858: 59), de tal maneira que uma mesma residência podia ter uma grande variedade de tipos decorativos, sem um investimento muito alto. Quando voltadas para um público específico, as chamadas publicitárias eram direcionadas mais para o sexo masculino, tendo sido encontrado apenas um reclame dirigido ostensivamente às

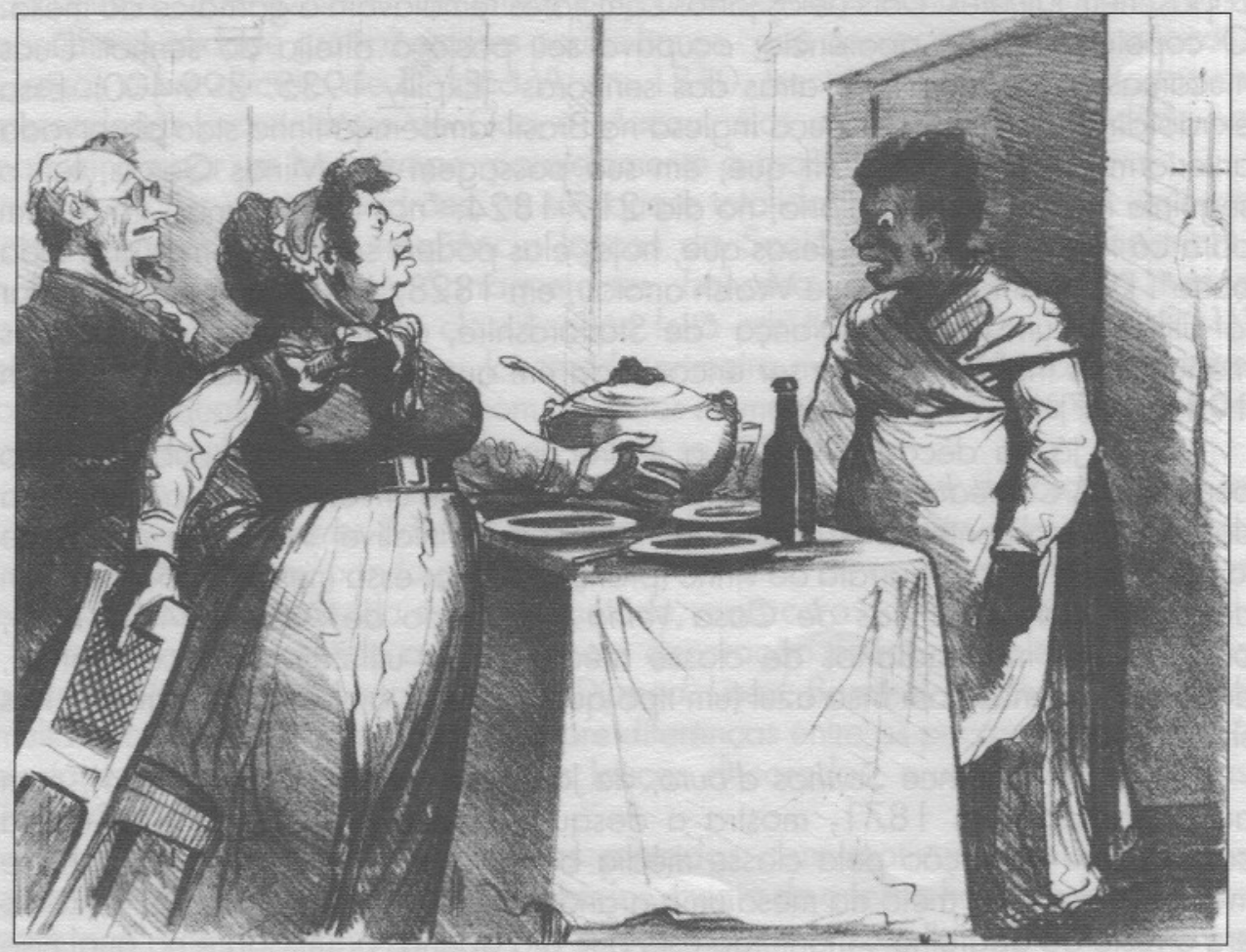

- Então Mariana, o que quer dizer isto? ha mais de tres mezes que não pôes louro na comida!

- Pois minha senhora não disse que nhonhô veio carregado de louros do Paraguay? eu estou sempre a espera do louro, e por isso não compro mais.

Prancha 4: A louça branca na esfera privada: cena doméstica representada em anedoła do periódico A Comédia Social, em 1870. 
mulheres, em A Terrina Fluminense, já na última década do século (A Familia 1890|. Assim sendo, não há elementos suficientes para se afirmar categoricamente, como fizeram Klein (1991) e Wall (1994: 135), que cabia às mulheres, no Rio de Janeiro, a escolha da louça doméstica.

Nos registros arqueológicos da primeira metade do século vem sendo constatado o predomínio, em seguida à louça branca de baixa qualidade, de peças decalcadas em azul e outras tonalidades, que no entanto parecem diminuir nos contextos da segunda metade. Em compensação, a branca aumenta de forma considerável e, paralelamente às peças destinadas à cozinha e à higiene íntima, surgem formas mais requintadas e serviços completos de mesa em pastas mais resistentes como a ironstone, e de melhor qualidade e maior preço, como a porcelana.

Esta impressionante freqüência de louças nas unidades domésticas que vêm sendo investigadas pode ser atribuida não só à extraordinária importância assumida pela cerimônia do jantar à época, mas parece corresponder sobretudo à reprodução, no Brasil, do fenômeno ocorrido na Europa, nos séculos XVIII e XIX. A mania pelas porcelanas, que atingiu as classes dominantes e fascinou as médias, transformada em verdadeiro surto epidêmico com a descoberta do seu simulacro, a faiança, contaminou todo o mundo ocidental.

Necessitando expandir cada vez mais seus mercados consumidores, os ingleses, valendo-se da conjuntura extremamente favorável criada pela transferência da corte portuguesa para o Brasil, despejaram maciçamente seus produtos no país. Dirigidas para uma sociedade ávida por sinais de identificação com os mais ricos, mais fortes e poderosos, de tal modo que através da associação com esses objetos pudesse obter a própria legitimação, as louças não encontraram obstáculos para a sua extraordinária difusão.

Parece inquestionável, a julgar pela notável variedade e expressiva quantidade de faianças recuperadas, que a mesma atração avassaladora tomou conta dos cariocas no século passado, impelindo-os para aquisições maciças desses produtos. Desta forma, em plena ordem escravocrata, o consumo de massa foi prematuramente introduzido na sociedade do Rio de Janeiro.

Um significado para a louça doméstica

Toda cultura material possui evidentemente um significado. Entretanto, este significado não the é inerente e deve ser buscado nas relações entre os componentes do sistema ao qual ela está integrada (Douglas \& Isherwood 1980: 72). Assim sendo, o processo de expansão da produção e comércio das louças não foi um fato isolado. As mudanças na cultura material somaram-se à progressiva complexificação do ritual do jantar, ao protocolo paulatinamente mais rígido, à cada vez mais intrincada codificação dos gestos e dos movimentos do corpo, atestando a reordenação de todo o subsistema alimentar.

movimento geral no sentido de uma maior individualização e especialização, ocorrido ao longo do século XIX, atingiu também o domínio da alimentação, em todas as suas expressões, como foi visto. Entre elas, o equipamento de mesa, que se diversificou consideravelmente: novas formas foram inventadas e adaptadas a funções antes preenchidas por implementos multifuncionais, 
sofisticando sobremaneira o aparato destinado ao consumo de alimentos. Os aparelhos de jantar completos, compreendendo travessas rasas e fundas em diversos modelos, sopeiras, molheiras, jarras, fruteiras, cremeiras, etc., tornaram-se uma exigência do novo estilo de servir, assim como os três formatos diferentes dos pratos de comer - fundos, rasos e sobremesa - uma adequação ao modelo prevalente da refeição em três cobertas.

Os talheres, por sua vez, acompanharam essa diversificação, especializando-se do mesmo modo. Surgiram formas menores destinadas à sobremesa, chá e café, modelos especiais para queijos, frutas, ostras, bolos, e, em especial, para os peixes. Estes últimos deveriam ser de prata, dispensando a faca de lâmina cortante cujo metal corrompia o delicado sabor dos alimentos do mar, deixando-os com um gosto intragável, e receber uma lâmina apenas pontiaguda, sem corte, própria para um tipo de carne bem macia, porém com muitas espinhas. Copos e taças diversificaram-se da mesma maneira, ajustando-se os formatos aos diferentes tipos de bebidas servidos durante a refeição.

A nova compartimentação da unidade doméstica e o surgimento da sala de jantar; a especialização do seu mobiliário e adequação às funções de exibir e guardar alfaias, oferecer e ingerir alimentos; sua disposição e ordenação espacial; as alterações no modo de servir e na estrutura da refeição; as formas de comportamento à mesa e a sofisticação do sev equipamento, todas essas mudanças na cultura material foram parte de um mesmo processo, tendo sido socialmente produzidas para transmitir mensagens.

Em um momento de intensa mobilidade social, como o da emergência e fortalecimento da burguesia no século passado, as classes dominantes necessitavam de instrumentos de diferenciação suficientemente eficazes para manter à distância os ascendentes e assegurar a manutenção das suas posições. $\bigcirc$ domínio da alimentação, pelas suas peculiaridades, ofereceu condições extremamente favoráveis para o desenvolvimento dessas estratégias e se transformou em um bem sucedido campo para a demarcação de limites sociais, no qual divisões culturais eram constante e sutilmente reafirmadas.

No século XVIII, a aristocracia elegeu as porcelanas como um poderoso elemento de distinção, com a suntuosidade promovendo a discriminação social. Seu apelo visual e simbólico foi de tal forma intenso, que disparou um processo vertiginoso de consumo, absolutamente sem precedentes. A percepção aguda de Wedgwood quanto à ânsia dos segmentos médios em se equiparar à classe ociosa e quanto ao mecanismo vertical de difusão do gosto, levou-o ao desenvolvimento de novas conquistas tecnológicas para atender a esse mercado em expansão, que acabaram possibilitando às manufaturas de Staffordshire o desencadeamento da produção em massa.

A revolução de consumo provocada pela descoberta de um material muito mais barato e de efeito semelhante ao da porcelana diminuiu consideravelmente a eficácia da louça como marcador de classe. Em meados do século; as faianças decalcadas em azul e branco-disseminadas por "todos os pontos do globo" e por todas as mesas - desqualificaram-se totalmente. Assim sendo, impôs-se encontrar, no âmbito do próprio sistema de alimentação, um sucedâneo que deixasse bem marcadas as fronteiras entre os bem-nascidos e os arrivistas, tão ou mais eficiente que a louça. 
serviço de mesa à la russe, que nas primeiras décadas pareceu tão inadequado a Antonin Carême e difícil de ser adaptado aos hábitos franceses, tornou-se um sucesso em Paris, não por acaso na sua segunda metade, espraiando-se por todas as áreas de influência da capital francesa. Justo no momento em que - por efeito da disseminação das faianças pelos segmentos médios - era preciso encontrar um novo elemento de diferenciação, o modelo russo foi adotado. Desnecessário na primeira metade, quando as louças ainda eram um poderoso meio de distinção - e por isso desprezado por Carême - tornou-se imprescindível após a sua extraordinária difusão.

Exigindo, além de um perfeiło domínio das maneiras à mesa, ambientes requintados, mobiliário adequado, aparehos completos, jogos de taças, faqueiros, um vasto elenco de acessórios e, em especial, um staff de criados muito bem treinados, constituiu uma efetiva barreira para os que desconheciam suas minuciosas regras. A tentativa de reproduzir o estilo sem obedecer a todas essas particularidades tornava a cerimônia caricata, grotesca, de tal forma que, como recurso diferenciador, tornou-se insuperável ${ }^{36}$. Demandava sem dúvida alguma dinheiro, muito dinheiro, para custear o ambiente luxuoso e a vasta criadagem especializada, mas antes de tudo requeria educação, elegância, distinção e garbo.

Os arrivistas eram reconhecidos e barrados por sutilezas como, por exemplo, tipos de talheres e sua disposição à mesa. Na França, eles eram voltados para baixo, de modo a exibir ostensivamente o brasão ou monograma de família impresso na face posterior, o que tornava o espaço em branco, não gravado, uma constrangedora denúncia. Talheres de peixe, por se tratar de inovação recente, não existiam nos antigos faqueiros de prata passados como herança de pais para filhos, e atestavam a falta de tradição e berço daqueles que os colocavam à mesa. A pátina, aqui entendida no sentido que McCracken conferiu ao termo ${ }^{37}$, tornou-se um divisor de águas, separando nitidamente a riqueza herdada, dá riqueza adquirida. Tampovco a impressionante quantidade de manuais de boas maneiras despejada no mercado e avidamente consumida, em muitos casos redigidos anonimamente ou sob pseudônimo pelos próprios membros da aristocracia decadente, fornecia os instrumentos necessários para transpor a incomensurável barreira entre uma condição e outra.

avanço inexorável da classe burguesa, no entanto, e o poder esmagador que o dinheiro the conferia acabou impondo definitivamente os novos-ricos, como Brillat-Savarin expressou de forma tão eloqüente, ao expor a rendição dos duques aos financistas. $O$ dinheiro finalmente assumiu seu posto como o novo divisor de águas, confinando os antigos valores a um pequeno segmento ainda e sempre prestigiado, mas destituído de qualquer poder.

Na periferia desse processo, o Brasil recebeu na primeira metade do século o impacto brutal da expansão das manufaturas inglesas, após a abertura dos portos. O país foi inundado pelas exuberantes faianças decalcadas e em sua ânsia de identificação com os valores franco-ingleses, em busca de reconhecimento, a sociedade foi absorvendo gradativamente as formas de comportamento delas indissociadas. Mesclando-as de modo peculiar às suas próprias tradições, fortemente calcadas nos hábitos dos colonizadores, criou expressões híbridas, marcadas por acentuados contrastes. A observação feita por Kidder, em torno de 1840, ilustra bem esse aspecto: "Era rico e farto o serviço de mesa, mas reinava
36. Atualmente ainda se mantém, nas ocasióes formais, uma variante do jantat a la russe, que na América - e também no Brasil - ficou conhecido como serviço à francesa. Sua eficácia como instrumento de diferenciação até hoje não foi superada. Da mesma forma a estrutura das refeições, tanto formais (ver Pellaprat 1952) quanto familiares (a tripartição $\mathrm{cm}$ três cobertas), se manteve em suas linhas gerais, atestando o conservadorismo do domínio alimentar, no qual as mudanças se operam sempre lentamente e a contragosto (Douglas 1982: 88).

37. Propriedade fisica e simbólica que confere status, na medida em que assegura, através de pequenos sinais de tempo acumulados na superficie de um objeto, que ele é propriedade da família há várias gerações e não se trata de aquisição recente (McCracken 1988: 32). 
38. Curiosamente, entretanto, há na biblioteca pessoal de Rui Barbosa um volume de um manual destinado à administração de empregados domésticos (tarefas, salários, alimentação, etc.), The duties of servants, publicado em 1894 by a member of the aristocracy, em cuja capa consta o carimbo de sua assinatura, ou seja, a sua marca, e não a de sua muTher, Maria Augusta. Isto permite supor possiveis ingerências masculinas até mesmo nesses bastidores. certa confusão entre as dez ou doze copeiras que poderiam ser perfeitamente substituídas por apenas duas que conhecessem bem o métier. A baixela era das mais finas e caras. As mesas e cadeiras, miseráveis. A roupa de cama, as fronhas e as toalhas dos dormitórios eram de algodão, mas ornadas com largos babados de cambraia. Parecia que o contraste imperava por tudo" (Kidder 1951: 203).

A implantação do ritual do jantar foi feita nos mesmos moldes. Se o topo da sociedade, em especial os estrangeiros aqui residentes, os que foram educados na Europa ou lá iam regularmente tinham condições de reproduzi-lo de forma satisfatória, o mesmo não ocorria em relação aos ascendentes, resultando de suas tentativas as confusas misturas já descritas. Enquanto estratégia de negociação, no entanto, foi rigorosamente fiel ao modelo original, servindo não só para impor e manter limites sociais, mas também para reafirmar divisões culturais que expressavam a ordem vigente no país.

A louça doméstica constituiu um dos mais importantes suportes materiais dessa estratégia. Considerada atualmente como pertencente à esfera feminina, faz parte hoje em dia dos utensílios da mulher. É através dela que se transmite a tradição familiar, herança passada de mãe para filha, carregada de lembranças e afetividade (Csikszentmihalyi \& Halton 1981: 82-3). Entretanto, não foi assim no século passado. O consumo cerimonial de alimentos - sobretudo na sua primeira metade - era um domínio eminentemente masculino. Enquanto espaço destinado sobretudo a negociações e manifestações de poder, era evidentemente controlado pelos homens. O dono da casa comandava o espetáculo, liderando o cortejo que levava os convidados à mesa, servindo os alimentos, trinchando os assados, conduzindo a conversação. O equipamento era do mesmo modo masculino: sobre pratos, taças e talheres era aposta a marca do senhor - as suas iniciais - sob a forma de brasões e monogramas. À senhora cabia apenas o último lugar no cortejo, ou, no papel de coadjuvante, o serviço de alimentos de menor importância, como sopas e sobremesas, não obstante todo esse aparato ser fruto exclusivo do seu trabalho nos bastidores ${ }^{38}$.

processo de fabricação da louça nas manufaturas, por seu lado, confirmava esse caráter masculino. Toda a sua concepção, tanto do ponto de vista técnico, quanto da forma e decoração; a sequêencia de preparo da argila, moldagem, modelagem, queima, aplicação de padrões decorativos e glasuras, assim como as tarefas de supervisão, monitoramento e comercialização estavam ao encargo de homens. Às mulheres e meninas, mão de obra barata, era confiada somente a pintura (ver Blaszczyk 1994). Deste modo, as louças do século passado foram idealizadas, fabricadas e comercializadas por homens; eram eles que lançavam estilos e modas, ditando o que deveria ser usado nas mesas, assim como foram homens todos os grandes louceiros do século XIX.

Yentsch, em seu trabalho sobre a divisão simbólica das louças /Yentsch 1991 a) chamou atenção para o fato de que propriedades físicas são freqüentemente utilizadas como demarcadores de posições sociais, de tal maneira que alguns elementos da cultura material podem adquirir significados simbólicos através da sua associação com quem os utiliza. Nessa linha de pensamento ela atribuiu, no contexto da segunda metade do século XVIII, as cerâmicas em cores terrosas e tons esverdeados - vinculadas à terra e à vegetação - ao domínio feminino, numa extensão do mesmo elo metafórico que une a mulher à natureza. 
Utilizadas na transformação da comida, do seu estado natural (cru) para o cultural (cozido), uma tarefa eminentemente da mulher, essas louças estavam mais próximas da natureza que da cultura, o que fazia delas, indubitavelmente, artefatos "femininos". Em contrapartida, as louças brancas foram associadas à esfera masculina. Por se tratar de uma cor distante da natureza, artificial, elas estariam mais próximas da cultura, sendo, portanto, artefatos "masculinos". A utilização diferencial dessas peças, ou seja, o uso doméstico, cotidiano, informal das louças terrosas versus o uso social, esporádico, formal da louça branca, confirmaria esse caráter simbólico, sobretudo se contrastada com outros aspectos, como o espaço no qual eram utilizadas láreas privadas, de baixo prestígio $x$ áreas nobres $e$ públicas das unidades residenciais) ou os alimentos aos quais estavam associadas (simples $x$ requintados).

No século XIX, entretanto, ocorreu um fenômeno de inversão desse simbolismo (Yentsch 1991b: 132). Com o impacto provocado pela louça decalcada, em sua primeira metade, as faianças brancas perderam prestígio, baixaram de preço, foram incorporadas aos segmentos médios e baixos da sociedade, com formas em grande parte associadas ao processamento da comida e à higiene íntima. Banidas dos espaços formais e confinadas às áreas íntimas e privadas das unidades domésticas, lá somaram-se às cerâmicas, integrando-se harmonicamente ao domínio feminino.

Equivocadamente entendida como "artificial" e distante do mundo natural no modelo de Yentsch, a louça branca na verdade remete à natureza, a depósitos de argilas claras, como o caulim, e a areias, na mesma medida em que as cerâmicas são associadas à terra. Até mesmo quando recebia decoração em relevo, os motivos que the eram apostos, como o tão popular padrão trigo, ou mesmo ramagens, frutos e flores, fortaleciam a sua vinculação com o mundo natural, o que a tornava absolutamente coerente com o universo da mulher.

Já em relação à louça decalcada, sobretudo a azul e branca, não apenas se empregava uma cor que não existe na natureza, como também os louceiros se esmeravam na produção de padrões decorativos fortemente "culturais" (motivos geométricos, vistas de castelos, cidades, abadias, etc.), reforçando seu vínculo com o domínio da cultura.

Endossando este modelo interpretativo, os contextos arqueológicos cariocas da primeira metade do século XIX, somados aos elementos fornecidos pelas fontes literárias e documentais, sugerem que o universo doméstico estava fortemente estrułurado em uma divisão de gênero, que se externalizava da seguinte maneira: um espaço íntimo, privado, domínio da mulher, partilhado com outras categorias subalternas como agregados, escravos, etc., cujo centro de gravidade era a produção de alimentos para o núcleo familiar, vale dizer, a cozinha suja e fumarenta.

Os relatos dos viajantes que por aqui passaram nesse período destacam unanimemente a condição reclusa da mulher brasileira, que raramente aparecia para pessoas de fora, sobretudo no interior. Enclausurada na parte íntima da casa, vivia confinada à cozinha, no exercício das tarefas domésticas, vestida com total desmazelo, mal calçada e despenteada ${ }^{39}$. Em 1815, disse Adèle Toussaint-Samson: "Quem for admitido à (sua) intimidade, acha-la-á pela manhã de tamancas, sem meias, com um penteador de cassa por vestido (...)" lapud leite
39. Tanto nas áreas urbanas quanto rurais, $c f$. Stein (1985: 220). 
40. Em A escrava Isaura (1978:125), Bernardo Guimarães coloca esse equipamento de mesa, "nos primeiros anos do reinado de D. Pedro I", como um dos principais ítens de riqueza de uma unidade doméstica:"Esta fazenda com todos os escravos, esta casa com seus ricos móveis, $e$ sua baixela (grifo nosso), nada disso the pertence mais; de hoje em diante - senhor não pode dispor aqui nem do mais insignificante objeto".
1984: 44). Em 1819, Leithold e Rango (1966: 27) acusavam "o belo sexo" de não fazer absolutamente nada, pouco se deixando ver por estranhos. Por sua vez, Langsdorff fez a seguinte observação em seu diário de viagem, no dia 16-6-1824: "tal como em outros lugares, tampouco aqui foi possível ver as criaturas femininas da casa", o que foi confirmado por Burmeister em meados do século, nos seguintes termos: "Ainda não consegui ver sua mulher (do anfitrião), embora the ouvisse a voz vinda da cozinha, onde ela andava atarefada; seguindo os costumes brasileiros, a mulher não saía desse seu reino natural" (Burmeister 1952: 265).

Por essa mesma época, o conde de Suzannet descrevia "a cozinha como o abrigo inviolável das brasileiras. Lá, vestidas com uma camisa, e, às vezes, uma saia, elas presidem as fainas domésticas, dando ordens às negras ou preparando elas mesmas os petiscos. Não penetrei jamais nesses recintos sagrados; mas alguma porta entreaberta por curiosidade permitiu-me verificar a sujeira que reina nesse interior" (Suzannet 1957: 46). Esse caráter "sagrado" das áreas privadas foi confirmado duas décadas mais tarde por Burton, nos seguintes termos: "o gineceu e a cozinha (...) são lugares interditos. A sala de jantar fica muitas vezes no interior da casa, onde o elemento feminino, ajuntando-se atrás das portas, pode ver o estranho, sem ser visto" (Burton 1976: 259). Este perfil doméstico, entretanto, contrastava vivamente com a imagem pública da mulher, que saía à rua sempre luxuosamente trajada e coberta de jóias.

Um tal contexto reforçava a associação simbólica da mulher com a natureza, distanciada da cultura, e portanto hierarquicamente inferior àqueles que estavam na situação oposta. No caso, o espaço público da casa, acessível aos de fora, cujo centro era a luminosa e requintada sala de jantar, que exibia o que a unidade doméstica tinha de mais precioso - as exuberantes e coloridas faianças ${ }^{40}$ - domínio masculino por excelência.

Em uma sociedade de estrutura dual, como a escravista, em que os segmentos médios, ainda pouco expressivos, estavam em processo de consolidação, a organização, nos mais diferentes setores, acompanhava essa dualidade. A divisão de gênero era, na verdade, mais um domínio onde se expressavam as relações de dominância e subordinação que regiam essa sociedade.

Na segunda metade, entretanto - e sobretudo nas últimas décadas - com a desqualificação das faianças decalcadas a louça branca voltou triunfalmente à sala de jantar, recuperando seu antigo prestígio. Também não por acaso, sua aclamação nos espaços cerimoniais coincidiu com a mudança do papel feminino na sociedade. A mulher da ordem escravocrata, oprimida, escondida, confinada à cozinha, fraca e dependente tornou-se incompativel com a intensificação das práticas capitalistas. Âs grandes nações européias - em particular à Inglaterra - não interessava mais uma estrutura fortemente polarizada, com apenas um pequeno segmento do topo em condições de adquirir seus produtos manufaturados. Era preciso atenuar os dualismos, transformar a mão-de-obra escrava em assalariados com poder de compra, retirar essa mulher do fundo da casa e leváta às ruas, aos estabelecimentos comerciais, para desta maneira ampliar o consumo e expandir o mercado. Impunha-se antes de tudo a formação de classes médias fortes. A nova ordem, que se aproximava velozmente, a passos largos, exigia uma figura feminina ativa, dinâmica, participante e influente, consumindo bens e tomando decisões. 
Em 1889, com o país acompanhando, ainda que a reboque, as importantes transformações que o século XIX reservou ao sexo feminino (Duby \& Perrot 1991: 91, já começavam a se alterar substancialmente as suas perspectivas de vida. No periódico A Família, conselhos para as boas esposas incluiam, com ênfase, a necessidade delas se dedicarem em pé de igualdade às tarefas domésticas e à intensa vida social: "porque sabe(m) conversar na sala com facilidade e chiste, nem por isso deixa(m) de saber estar na cozinha". Rompida a muratha da esfera privada, escravocrata, a mulher saiu dos bastidores, ganhou a cena principal e chegou aos salões pelos braços do capitalismo, mas trazendo consigo a louça branca que a simbolizava, agora com uma nova roupagem.

Por sua vez, o controle masculino do ritual à mesa foi consideravelmente amenizado com o serviço à la russe, na medida em que as importantes atribuições de trinchar assados e partilhar alimentos foram repassadas aos criados, abrindo um espaço maior para a participação da mulher. Essa redefinição de papéis masculinos e femininos se refletiu na ordenação espacial à mesá. Se antes anfitrião e anfitriã sentavam-se rigidamente em oposição um ao outro - mais uma expressão simbólica dessa forte divisão de gênero - outra distribuição passou a ser tolerada, como foi visto anteriormente em Machado de Assis, em que ambos podiam sentar-se lado a lado.

A multiplicidade de regras relativas a essa distribuição, com os anfitriões ora à cabeceira, ora no centro da mesa, ora em oposição, ora lado a lado, numa verdadeira "dança das cadeiras", refletia a intensa mobilidade social na confusa transição do império escravocrata para o regime republicano progressivamente capitalista (ver Andrade Lima 1994). A inexistência de uma regra única, sólida e duradoura para a essa disposição espacial, em um domínio tão conservador, atesta inequivocamente a incessante redefinição dos papéis sociais naquela conjuntura.

Em uma sociedade ambivalente que simultaneamente cultivava duas tradições culinárias, a francesa, complexa, formal, refinada, dirigida para fora, masculina; e a brasileira, simples, popular, informal, voltada para dentro, feminina. Em que a delicadeza das louças contrastava com os modos grosseiros à mesa; onde saúdes e palitos desafiavam o bom tom em evidente confronto com os códigos europeus, vivia-se um processo esquizóide, no qual "a persona formal do indivíduo, em ocasiões sociais, era mais européia e a familiar, brasileira", como bem mostrou Needell 11993: 1801, coexistindo conforme as circunstâncias. Nela foi utilizada a linguagem simbólica das louças para transmitir mensagens sobre o modo como estava organizada, bem como para reforçar os princípios sobre os quais estava estruturada, expressando metaforicamente relações de dominância e subordinação. O ritual do qual era parte integrante delimitava fronteiras, mediava conflitos e negociava interesses, usando o simbolismo de gênero como uma das estratégias de sustentação da sua dualidade.

Tantos contrastes e contradições, permanentemente apontados ${ }^{41}$, nada mais eram que conflitos entre o gosto de classe, de inclinação, e o gosto de vontade de um Brasil arrivista, emergente, que aspirava à ascensão social lançando mão de recursos como a emulação, a imitação, para se legitimar perante a aristocrática e bem-nascida Europa, em patéticas tentativas de erodir as diferenças entre centro e periferia. Contrastes e contradições que o capitalismo, então nascente, só viria a acirrar no país do simulacro e do arremedo.
41. Kidder, por volta de 1840 , fez a seguinte observação: "Os brasileiros sabem perfeitamente apreciar os artigos finos que o comércio thes apresenta, sem contudo deixar de se valer da produção local e dos pratos regionais que os estrangeiros levam tanto tempo para apreciar e que são realmente excelentes" (1951: 73). 


\section{In memoriam}

seu valor.

Aos meus pais, que me mostraram a beleza das louças e me ensinaram

Aos meus sogros, Oswaldo e Marina Lima, herdeiros e sucessores da Casa Moniz, citada neste artigo, estabelecida no século XIX à rua dos Ourives e posteriormente à rua do Ouvidor, pelas muitas histórias que me contaram.

\section{FONTES E BIBLIOGRAFIA CITADAS:}

\section{FONTES}

1. Manuais de boas maneiras

ALLEN, L. G. Table service. Little, Brown. 1915. In: DOUGLAS, Mary (Ed.), Rules and meanings. Harmondsworth: Penguin Books, 1973. p. 219-20.

ALQ, Louise Alquié de Rieusseyroux [Mme. Louise d'Alq, pseud.]. Le savoir vivre - dans toutes les circonstances de la vie. 14. ed. rév. et corrigée par l'auteur. Paris: François Ebhardt, 1877.

ANON. Modern Etiquette in Private and Public. Frederick Warne, 1872. In: DOUGLAS, Mary (Ed.) Rules and meanings. Harmondsworth: Penguin Books,1973, p. 216-18.

BAFFANVILL, Mme. la Contesse. Almanach du savoir vivre: petit code de la bonne compagnie. Paris: E. Plon, 1878.

BY A MEMBER OF THE ARISTOCRACY. Manners and rules of good society or solecisms to be avoided. 18. ed. entirely re-written. London; New York: Frederick Warne, 1892.

BY A MEMBER OF THE ARISTOCRACY. The duties of servants: a practical guide to the routine of domestic service. London; New York: Frederic Warne, 1894a.

BY A MEMBER OF THE ARISTOCRACY. Waiting at table: a practical guide. London; New York: Frederic Warne, 1894b.

CAMPBELL, Gertrude Elizabeth. Complete etiquette for gentlemen. London: Cassell, [18-].

CAMPBELL, Gertrude Elizabeth. Etiquette of good society. London: Cassell, 1893.

COSTA, D.Antonio Macedo. Compêndio de civilidade cristã. Braine-le-Comte: Imprensa da Viúva Carlos Lelong, 1880.

DANVERS, Mrs. Delano. The ways of society: a social guide. London: Werner Laurier, [18-].

FRANKLIN, Alfred Louis Auguste. Le repas. Paris: E. Plon, 1889.

NAZARETH, Beatriz. Manual de civilidade e etiqueta: regras indispensáveis para se freqüentar a boa sociedade. 9.ed. Lisboa: Arnaldo Bordalo, 1914 Encyclopedia Bordalo (Premiado na Exposição do Rio de Janeiro de 1908). 
PIMENTEL, João Maria. A sciencia da civilização. 2.ed., Porto: E. Chardron, 1877.

RAISSON, Horace Napoléon. Code civil, manuel complet de la politesse, du ton, des manières de la bonne compagnie. 4.ed., rev. aug. Paris: J. P. Roret, 1828.

RAISSON, Horace Napoléon. Code de la conversation, manuel complet du langage élégant et poli. Paris: J. P. Roret, 1829.

SIQUEIRA, João de Nossa Senhora da Porta (Sacerdote). Escola de política ou tratado prático da civilidade portuguesa. São Paulo: Nova Ed.Typ. de Santos, 1845.

2. Compêndios e Tratados de culinária:

BOSSI, Vitaliano. L'imperatore dei cuochi: manuale completo di cucina casalinga i di alta cucina. Roma: E. Perino, 1894.

BRILLAT-SAVARIN, Jean Anthelme. A fisiologia do gosto. São Paulo: Companhia das Letras, 1995.

ESCOFFIER. Ma cuisine. Paris: Flammarion, 1988.

PELLAPRAT, Henri Paul. L'art culinaire moderne: la bonne table française et étrangère. Paris: Jacques Kramer, 1952.

RODRIGUES, Domingos (Mestre da cozinha de Sua Majestade).Arte de cozinba. Lisboa: na oficina de João Antonio Reis, com licença da Real Mesa da Comissão Geral sobre o exame e censura dos livros, 1794.

3. Romances, contos, crônicas, ensaios

ALENCAR, José de. Sonbos d'ouro. Rio de Janeiro: José Aguilar, 1959a. v.1. Obra Completa

ALENCAR, José de. Cinco minutos. Rio de Janeiro: José Aguilar, 1959b. v.1. Obra Completa

ALENCAR, José de. A viuvinba. Rio de Janeiro, José Aguilar, 1959c. v.1. Obra Completa

ALENCAR, José de. Fragmentos. Rio de Janeiro, José Aguilar, 1959d. v.1. Obra Completa

ALENCAR, José de. Senbora. 26. ed. São Paulo: Ática., 1995a.

ALENCAR, José de. A pata da gazela. 12. ed. São Paulo: Ática, 1995b.

ALENCAR, José de. Lucíola. 19. ed. São Paulo: Ática, 1995c.

GUIMARÃES, Bernardo. A escrava Isaura. 8. ed. São Paulo: Ática, 1978.

MACEDO, Joaquim Manuel de. A moreninba. 10. ed. São Paulo: Ática, 1981.

MACEDO, Joaquim Manuel de. A luneta mágica. 6. ed. São Paulo: Ática, 1990.

MACHADO DE ASSIS, Joaquim Maria. Histórias da meia-noite. Rio de Janeiro, W. M. Jackson, 1942. 
MACHADO DE ASSIS, Joaquim Maria. Ressurreição. Rio de Janeiro: W. M. Jackson, 1944a.

MACHADO DE ASSIS, Joaquim Maria. A mão e a luva. Rio de Janeiro: W. M. Jackson, 1944́b.

MACHADO DE ASSIS, Joaquim Maria. Memorial de Ayres. Rio de Janeiro, W. M. Jackson, 1944c.

MACHADO DEASSIS, Joaquim Maria. Contos Fluminenses: Rio de Janeiro: W. M. Jackson, 1944d. 2v.

MACHADO DE ASSIS, Joaquim Maria. Histórias românticas. Rio de Janeiro: W. M. Jackson, 1944 e.

MACHADO DE ASSIS, Joaquim Maria. Papéis avulsos. Rio de Janeiro: W. M. Jackson, 1944 f.

MACHADO DE ASSIS, Joaquim Maria. Histórias sem data. Rio de Janeiro: W. M. Jackson, $1944 \mathrm{~g}$

MACHADO DE ASSIS, Joaquim Maria. Várias bistórias. Rio de Janeiro: W. M. Jackson, 1944h

MACHADO DE ASSIS, Joaquim Maria. Páginas recolbidas. Rio de Janeiro: W. M. Jackson, 19441.

MACHADO DE ASSIS, Joaquim Maria. Relíquias de Casa Velha. Rio de Janeiro: W. M. Jackson, 1944j. $2 v$.

MACHADO DE ASSIS, Joaquim Maria. Helena. Rio de Janeiro: W. M. Jackson, 1946a.

MACHADO DE ASSIS, Joaquim Maria. Memórias póstumas de Brás Cubas. Rio de Janeiro: W. M. Jackson, 1946b.

MACHADO DE ASSIS, Joaquim Maria. Quincas Borba. Rio de Janeiro: W. M. Jackson, 1946c.

MONTAIGNE, Michel de. Essais II: livre second. Paris: Gallimard, 1965.

PROUST, Marcel. À sombra das raparigas em flor. 2.ed. Rio de Janeiro: Globo, 1957.

PROUST, Marcel. Em busca do tempo perdido. 2.ed. Rio de Janeiro: Globo, 1957. 7v.

4. Periódicos:

ALMANACK ADMINISTRATTVO, MERCANTIL E INDUSTRIAL DA CORTE E PROVÍNCIA DO RIO DE JANEIRO. Rio de Janeiro:Typ. Universal de Laemmert, 1858-1884.

ARCHIVO CONTEMPORANEO ILLUSTRADO - 1889

ARCHIVO DAS FAMÍLIAS - 1881

O ARLEQUIM - 1867

BAZAR VOLANTE - 1866-1867

O BRAZIL ELEGANTE - 1898

A COMÉDIA SOCIAL - 1870 
CORREIO DAS DAMAS - 1836-1837

A ESTAÇÃO - 1887-1890

A FAMÍLIA - 1888-1894

O FLUMINENSE - 1882-1883

JORNAL DAS FAMÍLIAS - 1863-1878

JORNAL DAS SENHORAS - 1851-1853

A LUZ - 1872

O MENTOR DAS BRASILEIRAS - 1829-1830

NOVO CORREIO DE MODAS - 1853-1854

PERIÓDICO DOS POBRES - 1853-1855

PRIMAVERA - 1880

REVISTA POPULAR - 1860-1861

O SEXO FEMININO - 1875

O SORRISO - 1881

A VIDA FLUMINENSE - 1868

5. Relatos de viagens

BURMEISTER, Hermann. Viagem ao Brasil através das províncias do Rio de Janeiro e Minas Gerais. São Paulo: Livraria Martins, 1952.

BURTON, Richard Francis. Viagem do Rio de Janeiro a Morro Velbo. São Paulo: EDUSP; Belo Horizonte: Itatiaia, 1976.

DEBRET, Jean Baptiste. Viagem pitoresca e histórica ao Brasil. 3.ed. São Paulo: Livraria Martins, 1954. v.2

EBEL, Ernest. O Rio de Janeiro e seus arredores em 1824. São Paulo: Nacional, 1972. Brasiliana, v.351. EXPILLY, Charles. Mulberes e costumes do Brasil. São Paulo: Nacional, 1935. Brasiliana, v.57. EWBANK, Thomas. A vida no Brasil. Rio de Janeiro: Conquista, 1973. 2v.

GRAHAM, Maria. Diário de uma viagem ao Brasil. São Paulo: EDUSP, 1990. KIDDER, Daniel P.Reminiscências de viagens e permanência no Brasil. São Paulo: Martins, 1951. 
KIDDER, Daniel P.; FLETCHER, J.C. O Brasil e os brasileiros. São Paulo: Nacional, 1941. Brasiliana, v.205, v.205A.

LEITHOLD, T. von; RANGO, L von. O Rio de Janeiro visto por dois prussianos. São Paulo: Nacional, 1966.

LUCCOCK, John. Notas sobre o Rio de Janeiro e partes meridionais do Brasil. São Paulo: EDUSP; Belo Horizonte: Itatiaia, 1975.

MAWE, John. Viagens ao interior do Brasil. São Paulo: EDUSP, 1978.

POHL, João E. Viagem no interior do Brasil. Rio de Janeiro: INL, 1951. 2v.

SAINT-HILAIRE, Auguste de. Viagem às nascentes do rio S. Francisco. São Paulo: EDUSP; Belo Horizonte: Itatiaia, 1975.

SUZANNET, Conde de. O Brasil em 1845. Rio de Janeiro: Casa do Estudante do Brasil, 1957.

WALSH, R. Notícias do Brasil. Belo Horizonte: Itatiaia, 1985. v.1

6. Dicionários

ACADEMIA REAL DAS SCIENCIAS DE LISBOA.Diccionario da lingoa portugueza. Lisboa:Academia Real das Sciencias de Lisboa, 1793.

D'ALMEIDA,José Maria; LACERDA,Araujo Correa de. Diccionario da lingua portugueza. Lisboa: no escritório de Francisco da Silva, 1862.

FARIA, Eduardo. Diccionario da lingua portugueza. 2. ed. Lisboa:Typ. Lisboense de José Carlos d'Aguiar Vianna, 1850.

FARIA, Eduardo. Novo Diccionario da lingua portugueza. 4. ed. Rio de Janeiro: J. Villeneuve, 1859. $2 \mathrm{v}$.

FONSECA, José da. Diccionario da lingua portugueza. Feito inteiramente de novo e consideravelmente aumentado por J. I. Roquete. Paris: Guillard, 1881.

PINTO, Luis Maria da Silva. Diccionario da lingua brazileira. Ouro Preto:Typographia de Silva, 1832.

SILVA, Antonio Moraes. Diccionario da lingua portugueza. Lisboa: Officina de S.T. Ferreira, 1789.

SILVA,Antonio Moraes. Diccionario da lingua portugueza.6. ed. Melhorada e muito acrescentada pelo Desembargador Agostinho de Mendonça Falcão. Lisboa:Typographia de Antonio José da Rocha, 1858.

VIEIRA, Domingos. Grande dicionario português. Porto: E. Chardon, 1871.

II. BIBLIOGRAFIA

ANDRADE LIMA, Tania. Humores e Odores: ordem corporal e ordem social no Rio de Janeiro, século XIX. História, ciência, saúde - Manguinbos, v.2, n.3, p. 4-96, 1996. 
ANDRADE LIMA, Tania. De morcegos e caveiras a cruzes e livros: a representação da morte nos cemitérios cariocas do século XIX (estudo de identidade e mobilidade sociais). Anais do Museu Paulista: história e cultura material, São Paulo, n.sér., v.2, p.87-150.

ANDRADE LIMA, Tania et al.A tralha doméstica em meados do século XIX: reflexos da emergência da pequena burguesia do Rio de Janeiro. Dédalo, v.1, p.205-30, 1989. Publicação Avulsa.

ANDRADE LIMA, Tania; BRUNO, Maria Cristina O.; FONSECA, Marta Pereira Reis da. Sintomas do modo de vida burguês no Vale do Paraíba, século XIX: fazenda São Fernando, Vassouras, Rio de Janeiro (exploração arqueológica e museológica).Anais do Museu Paulista:História e cultura material, São Paulo, n.sér., v.1, p.179-206, 1993.

ARMINJON, Catherine; BLONDEL, Nicole. Objects civils domestiques. Paris: Imprimerie Nationale, 1984.

BAILEY, Douglas W. The Living house: signifying continuity. In: SAMSON, Ross (Ed.). The Social archaeology of houses. Edinburg: Edinburg University Press, 1990. Cap. I, Introduction, p. 1-18.

BAUDRILLARD, Jean. A sociedade de consumo. Lisboa: Edições 70, 1991.

BEAUDRY, Mary C.Archaeology and the historical household. Man in the Nortbeast, v.28, p.2738, 1984.

BENDER, Donald R. A refinement of the concept of household: families, co-residence, and domestic functions. American Antbropologist, v.69, p.493-504, 1967.

BLANTON, Richard E. Houses and bousebolds: a comparative study. New York: Plenum Press, 1994.

BLASZCZYK, Regina Lee. The aesthetic moment: china decorators, consumer demand, and technological change in the american pottery industry, 1865-1900. Wintertbur Portfolio: A Journal of American Material Culture, v.29, n.2/3, p.121-153, 1994.

BOURDIEU, Pierre. The Berber house. In: DOUGLAS, Mary (Ed.), Rules and meanings. Harmondsworth: Penguin Books, 1973. p. 98-100.

BOURDIEU, Pierre. A economia das trocas simbólicas. São Paulo: Perspectiva, 1974.

BOURDIEU, Pierre. La distinction: critique sociale du jugement. Paris: Minuit, 1979.

BOURDIEU,Pierre. Gostos de classe e estilos de vida.In:ORTIZ, Renato (Org.); FERNANDES, Florestan (Coord.), Pierre Bourdieu. São Paulo: Ática, 1983. p.82-121. (Grandes Cientistas Sociais, 39).

BRANCANTE, Eldino da Fonseca. O Brasil e a cerâmica antiga. São Paulo: Lytographica Ypiranga, 1981.

BRAUDEL, Fernand. Civilização material, economia e capitalismo - sécs. XVXVII: as estruturas do cotidiano. São Paulo: Martins Fontes, 1995.

BURNETT, John. Plenty and want: a social history of food in England, from 1815 to the present day. 3.ed. London: Routledge, 1989. 
CASCUDO, Luis da Câmara. História da alimentação no Brasil. Belo Horizonte: Itatiaia;São Paulo: Edusp, 1983. 2v. (Reconquista do Brasil: n. sér., 79-80).

CLARK Jr., Clifford E. Domestic architecture as an index to social history: the romantic revival and the cult of domesticity in America, 1840-1870. In: SAINT GEORGE, R. B., (Ed.), Material life in America: 1600-1860. Boston: Northeastern University Press, 1988. p. 535-49.

COYSH,A.W.; HENRYWOOD, R. K. The dictionary of blue $\&$ white printed pottery 1780 - 1880 . 6. ed., Suffolk: Antique Collector's Club, 1995.

CROW, Graham; GRAHAM,Allan. Constructing the domestic sphere: the emergence of the modern home in post-war Britain. In: CORR, Helen; JAMIESON, Lynn (Eds.), Politics of everyday life: continuity and change in work and the family. London: Macmillan, 1990.

CSIKSZENTMIHALYI, Mihaly; ROCHBERG-HALTON, Eugene. The meaning of things: domestic symbols and the self. Cambridge: Cambridge University Press, 1981.

DAVIDOFF, Leonore.Adam spoke first and named the orders of the world: masculin and feminine domains in history and sociology. In:CORR, Helen; JAMIESON, Lynn (Eds.), Politics of everyday life: continuity and change in work and the family. London: Macmillan, 1990.

DEETZ, James. In small things forgotten: the archaeology of early american life. New York:Anchor Books, 1977.

DOUGLAS, Mary. Deciphering a meal. In: GEERTZ, Clifford (Ed.), Myth, symbol and culture. New York: W.W. Norton, 1971, p.61-81.

DOUGLAS, Mary. Food as a system of communication. In: The Active voice. London: Routledge/ Kegan Paul, 1982.

DOUGLAS, Mary; ISHERWOOD, Baron. The world of goods: towards an anthropology of consumption. Harmondsworth: Penguin Books, 1980.

DUNCAN, James S. The house as a symbol of social structure. In:ALTMAN, Irwin;WERNER, Carol M. (Eds.), Home environments: human behavior and environment. Advances in theory and research. London: Plenum Press, 1985. v.8. p. 133-51.

DYSON, Stephen L. Material cuiture, social structure, and changing cultural values: the ceramics of eighteenth- and nineteenth century Middletown, Connecticut. In: DICKENS JR., Roy S. (Ed.), Archaeology of urban America: the search for pattern and process. New York:Academic Press, 1982. p.291-327.

ELIAS, Norbert. O processo civilizador: uma história dos costumes. Rio de Janeiro: Zahar, 1990.

FEATHERSTONE, Mike et al. The body: social process and cultural theory. Londres: Sage Publications, 1991.

FRAISSE, Genevieve; Perrot, Michelle (Dirs.). O século XIX. In: DUBY, George; PERROT, Michelle. História das mulberes no Ocidente. Porto:Afrontamento; São Paulo: Ebradil, 1991. v.4. 
FREIRE, Gilberto. Assucar. Rio de Janeiro: José Olympio, 1939.

FRIEDLANDER, Amy. Beyond regionalism: history: archaeology and the future. Historical Arcbaeology. Detroit, v.24, n.4. p.102-9, 1990.

GODDEN, Geoffrey A. Encyclopaedia of british pottery and porcelain marks. London: Barrie \& Jenkins, 1964.

GOFFMAN, Erving. A representação do eu na vida cotidiana. Petrópolis:Vozes, 1975.

GRAHAM, Sandra Lauderdale. Protę̧ão e obediência: criadas e seus patrões no Rio de Janeiro, 1860 - 1910. São Paulo: Companhia das Letras, 1992.

GUERRAND, Roger-Henri. Espaços privados. In: PERROT, M. (Org.), História da vida privada. São Paulo: Companhia das Letras, 1987, v.4, p. 325-411.

HARDYMENT, Christina. From mangle to microwave: the mechanization of household work. Cambridge: Polity Press, 1990.

HARRINGTON, Faith.The emergent elite in early 18th century Portsmouth society: the archaeology of the Joseph Sherburne houselot. Historical Archaeology. Detroit: v.23, n.1, p.2-18, 1989.

JAMESON, Robert. Purity and power at the victorian dinner party. In: HODDER, Ian (Ed.) The archaeology of contextual meanings. Cambridge: Cambridge University, 1987, p.55-65.

KELLY,Alison. The story of Wedgwood. New York:Viking Press, 1975.

KLEIN, Terry $H$. Nineteenth-Century ceramics and models of consumer behavior. Historical Archaeology. Detroit: v.25, n.2. p.77-91, 1991.

KOROSEC-SERFATY, Perla. Experience and the use of dwelling. In:ALTMAN, Irwin;WERNER, Carol M. (Eds.), Home environments: human behavior and environment. Advances in theory and research. London: Plenum, 1985. v.8, p. 73-91.

LAWRENCE, Roderick J. Public collective and private space: a study of urban housing in Switzerland. In: KENT, Susan (Ed.), Domestic architecture and the use of space: an interdisciplinary crosscultural study. New directions in archaeology. Cambridge: Cambridge University, 1990. p. 73-91.

LEITE, Miriam Lifchitz Moreira (Org.). A condição feminina no Rio de Janeiro, século XIX. São Paulo: Hucitec; Brasília: INL Pró-memória, 1984.

LEMOS, Carlos. História da casa brasileira. São Paulo: Contexto, 1989.

LOBO, Eulália Maria Lahmeyer. História do Rio de Janeiro (do capital comercial ao capital industrial e financeiro). Rio de Janeiro: IBMEC, 1978, v.1.

LUCAS, Michael T.A la russe, à la pell-mell or à la practical: ideology and compromise at the late nineteenth century dinner table. Historical Archaeology. Detroit, v.28, n.4, p.80-93, 1994.

MARSHALL, Jo. Kitchenware. London: BPC, 1976. 
MARTIN-FUGIER, Anne. Os ritos da vida privada burguesa. In: História da vida privada. São Paulo: Companhia das Letras, 1991. v.4: Da Revolução Francesa à Primeira Guerra.

MAURO, Frédéric. O Brasil no tempo de Dom Pedro II. São Paulo: Companhia das Letras, 1991.

MCCRACKEN, Grant. Culture and consumption: new approaches to the symbolic character of consumer goods and activities. Indianapolis: Indiana University, 1988.

MCKENDRICK, Neil. Josiah Wedgwood and the commercialization of the potteries. In: MCKENDRICK, Neil; BREWER, John; PLUMB, J. H., The birth of a consumer society: the commercialization of eighteenth-century England. Bloomington: Indiana University, 1982.

MILLER, Daniel. Material culture and mass consumption. Oxford: Basil Blackwell, 1987.

MILLER, George L. Classification and economic scalling of 19th century ceramics. Historical Arcbaeology, Detroit, n.14, p.1-40, 1980.

MILLER, George L. A revised set of cc index values for classification and economic scaling of English ceramics from 1787 to 1880 . Historical Archaeology, Detrit, v.25, n.1, p.1-25, 1991.

MROZOWSKI, Stephen A. Prospects and perspectives on an archaeology of the household: Man in the northeast, v.27, p.31-49, 1984.

NEEDELL, Jeffrey D. Belle époque tropical. São Paulo: Companhia das Letras, 1993.

NORWAK, Mary. Kitchen antiques. London: Ward Lock, 1977.

PERROT, Michelle. Funções da família. In: PERROT, M. (Org.), História da vida privada. São Paulo: Companhia das Letras, 1987. v.4, p.105-20.

PINHO, Wanderley. Salôes e damas do segundo reinado. 4.ed. São Paulo: Livraria Martins, 1970.

POUNDS, Norman. Heartb and bome: a history of material culture. Indianapolis: Indiana University, 1989.

QUEIRÓS, Maria Isaura Pereira de. Cultura, sociedade rural, sociedade urbana no Brasil. São Paulo: Livros Técnicos e Científicos/EDUSP, 1978.

ROBBEN,Antonius C. G. M. Habits of home: spatial hegemony and the structuration of house and society in Brazil. American Anthropologist. Washington: v.91, n.3, p.570-87. 1989.

ROBERTS, Marion. Living in a man-made world:gender assumptions in modern housing design. London: Routledge, 1991.

SAILE, David G. The ritual establishment of home. In: ALTMAN, Irwin; WERNER, Carol M. (Eds.), Home environments: human behavior and environment. Advances in theory and research. London: Plenum Press, 1985. v.8, p. 87-111.

SILVA, Maria Beatriz Nizza da. Cultura e sociedade no Rio de Janeiro (1808-1821). 2.ed. Rio de Janeiro: Nacional, 1978 
SAMSON, Ross (Ed.). The social archaeology of bouses. Edinburgh: Edinburgh University, 1990. Cap. I, Introduction, p.1-18.

SOMBART, Werner. Amor, luxo e capitalismo. São Paulo: Bertrand, 1983.

STEIN, Stanley J. Vassouras: um município brasileiro do café, 1850-1900. Rio de Janeiro: Nova Fronteira, 1985.

TANNAHILL, Reay. Food in bistory. Harmondsworth: Penguin, 1988.

VISSER, Margareth. The rituals of dinner: the origins, evolution, eccentricities and meaning of table manners. 2. ed. New York: Penguin, 1992.

WALL, Diana diZerega. The arcbaeology of gender: separating the spheres in urban America. London: Plenum Press, 1994.

WESTMAN, Bror. What does it mean to feel at home? In: GRON, O.; ENGELSTAD, E.; LINDBLOM I., (Eds.), Social space: human spatial behaviour in dwellings and settlements. [S.1.] Odense University Press, 1991.p. 17-20.

WETHERBEE, Jean. A second look at wbite ironstone. Lombard:Wallace Homestead, 1985.

WILLIAMS, Petra. Flow blue China. Jeffersontown: Fountain House East, 1981.

YENTSCH,Anne. The symbolic divisions of pottery: sex-related attributes of english and angloamerican household pots. In:McGUIRE, R.; PAYNTER, R.(Eds.), The Arcbaeology of inequality. Oxford: Blackwell, 19912. p.192-230.

YENTSCH, Anne. Engendering visible and invisible ceramic artifacts: especially dairy vessels. Historical Arcbaeology. Detroit: v.25, n.4. p.132-55, 1991 b. 


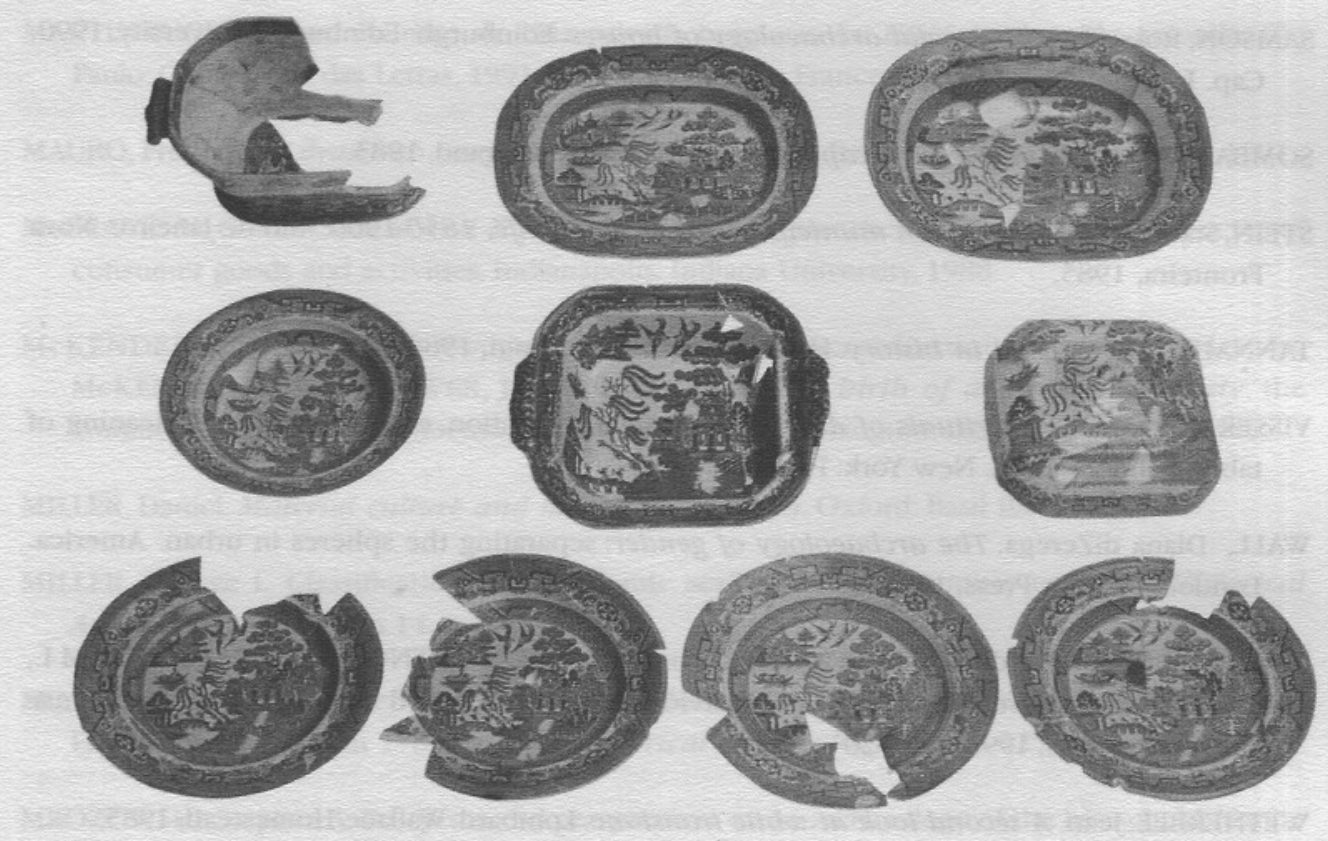

Foto 1: Faianças inglesas decalcadas, padrão Willow, um dos mais populares ao longo do século passado.A cena representada deu origem a uma lenda e um soneto: a bela filha de um rico mandarim, destinada a casar-se com um velho comerciante abastado, apaixona-se pelo secretário de seu pai, o qual, ao descobrir os encontros furtivos, persegue os dois enamorados. Estes, em sua fuga para alcançar um barco que os levaria a local seguro, atravessam a ponte, sob a proteção do jardineiro da propriedade. São entretanto alcançados, castigados até a morte, mas os deuses se apiedam do casal, transformando-o em dois amorosos pombinhos. Algumas das peças acima foram produzidas na região de Staffordshire, por Davenport e John Meir \& Son; as demais não apresentam marcas de fabricação. Proveniência: sítios históricos do Rio de Janeiro, século XIX.

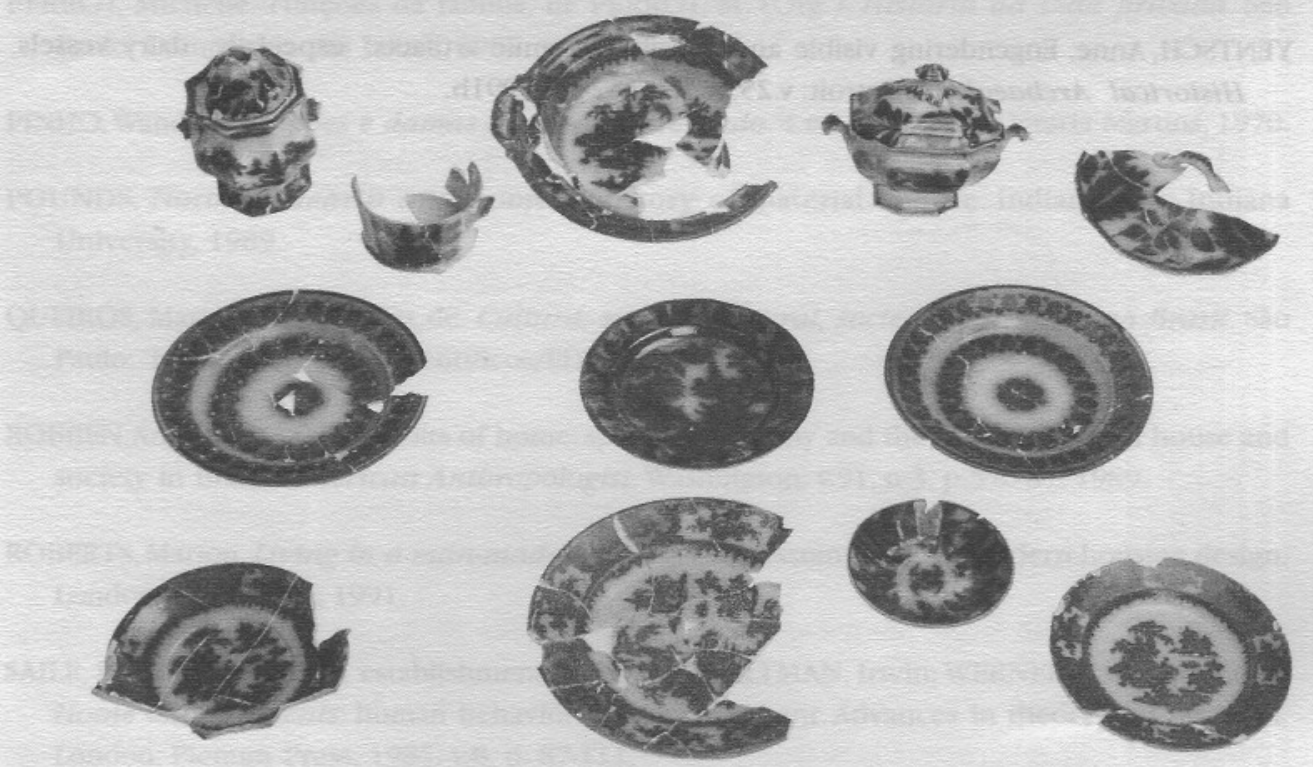

Foto 2:Faianças inglesas em azul borrão, com motivos orientais e florais.Algumas das peças acima foram produzidas na região de Staffordshire, por Baker \& Co. e C. Collinson \& Co.; as demais não apresentam marcas de fabricação. Proveniência: sítios históricos do Rio de Janeiro, século XIX. 


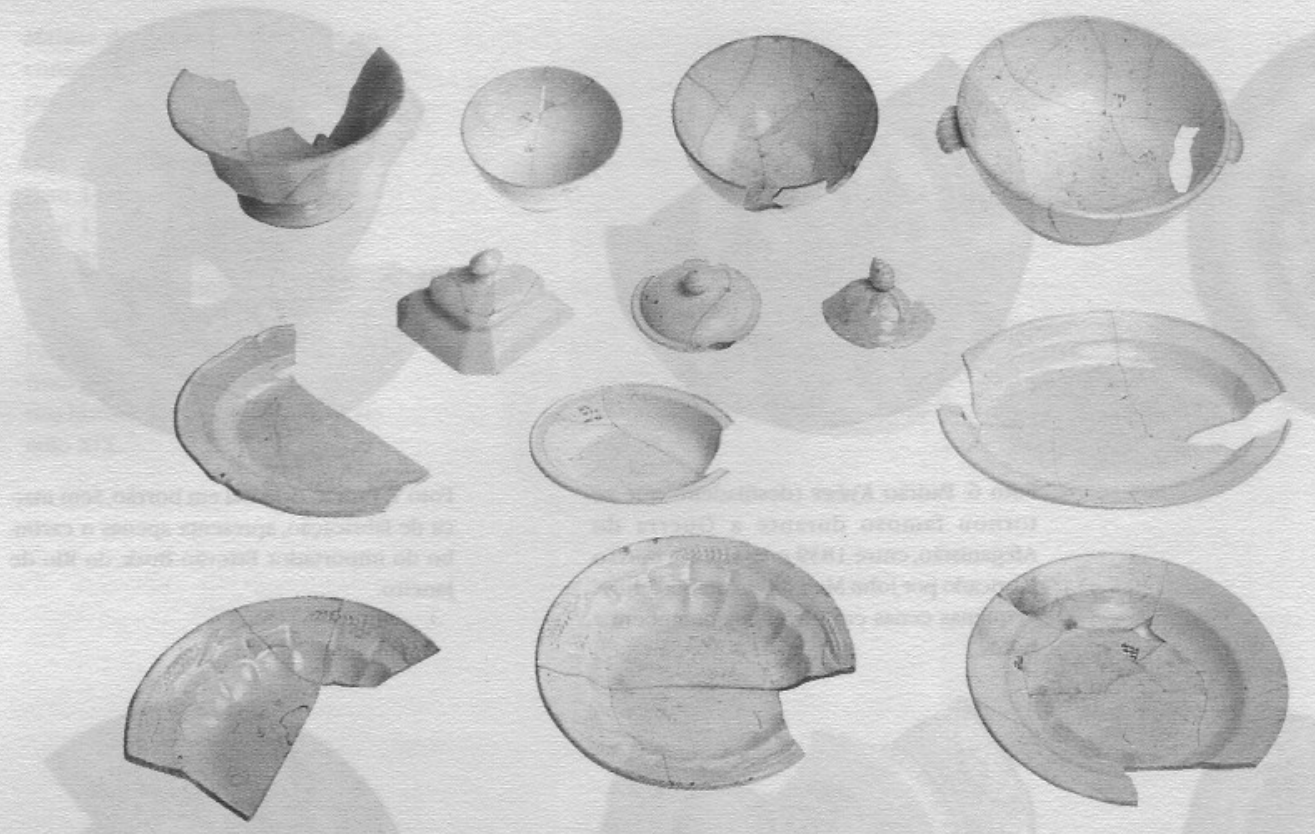

Foto 3: Faianças brancas sem marcas de fabricação. Apenas uma peça, em ironstone, datada do final do século passado, tem impresso o nome do fabricante:J. \& G. Meakin, de Staffordshire (prato inferior, à direita). Proveniencia: sítios históricos do Rio de Janeiro, século XIX

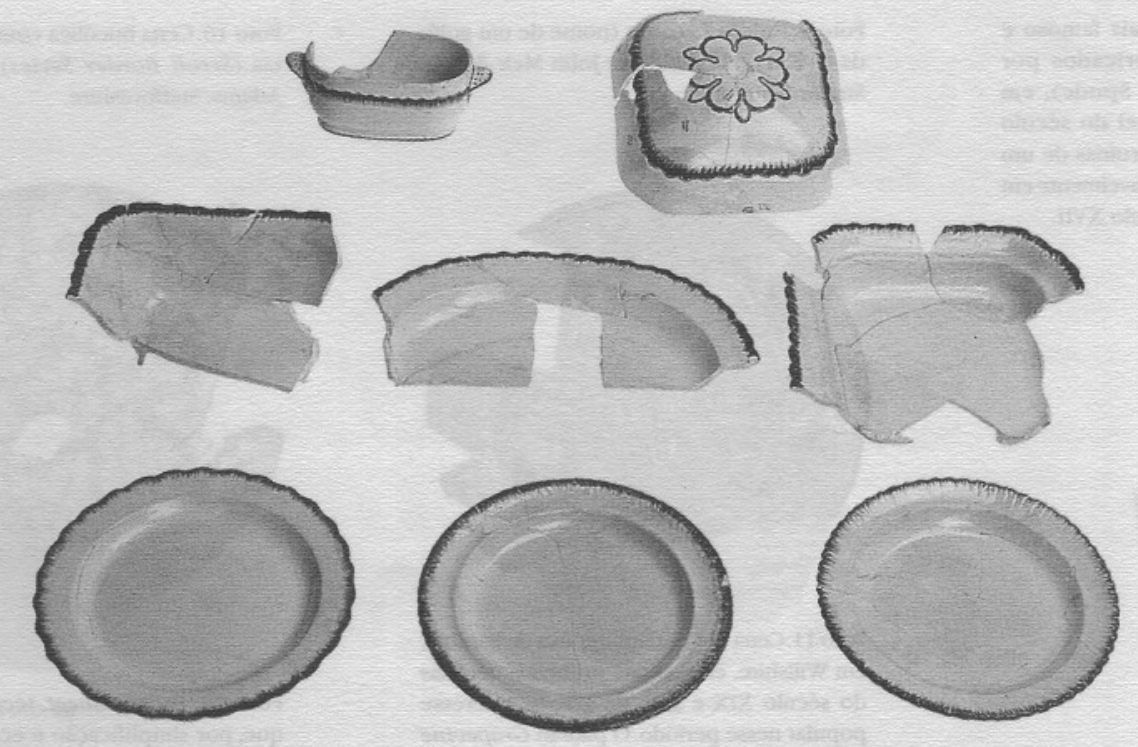

Foto 4: Faianças brancas, com decoração em shell edge.Apenas um prato apresenta o carimbo de Davenport, Staffordshire; as demais não apresentam marcas de fabricação. Proveniência: sítios históricos do Rio de Janeiro, século XIX. 


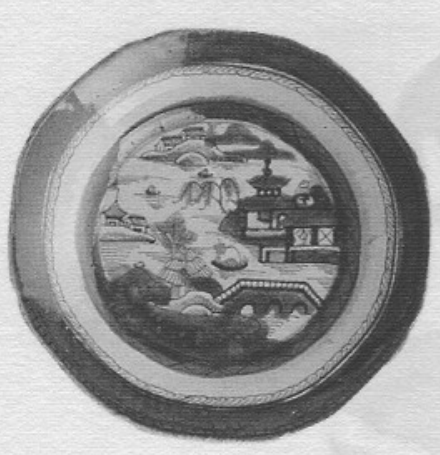

Foto 5 : louça de Macau.

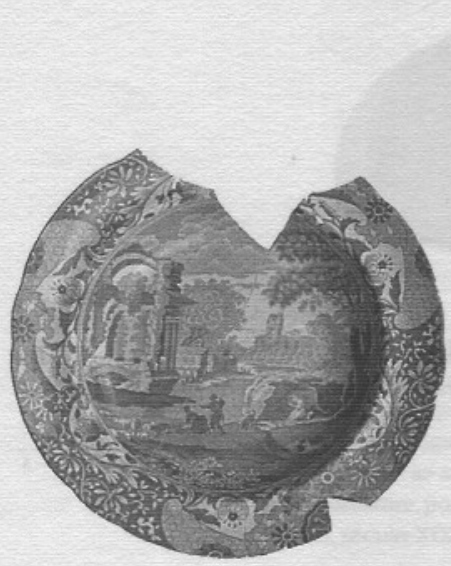

Foto 8: Padrão Italian, o mais famoso e difundido dos padrões fabricados por Copeland \& Garrett (Late Spode), em Staffordshire, segundo quartel do século XIX. A cena bucólica com as ruínas de um arco romano foi inspirada provavelmente em Frederick de Moucheron, século XVII.
Foto 9: Padrão Laconia (nome de um golfo da Grécia), fabricado por John Meir \& Son, Staffordshire.

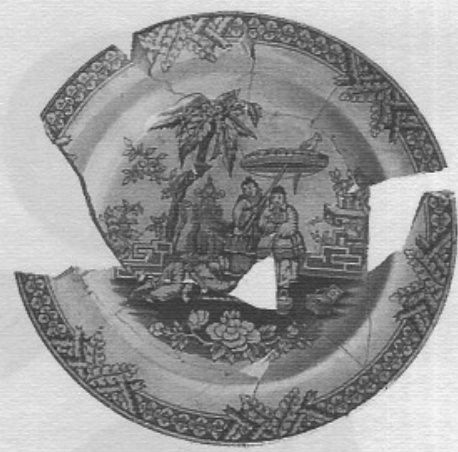

Foto 6: Padrão Kyber (desfiladeiro que se tornou famoso durante a Guerra do Afeganistão, entre 1839 e 1842), em borrão fabricado por John Meir \& Son, Staffordshire. Pequenas cenas em cartuchos compõem a borda.
Foto 7: Padrão oriental em borrão. Sem marca de fabricaçāo, apresenta apenas o carimbo do importador Estevão Busk, do Rio de Janeiro.

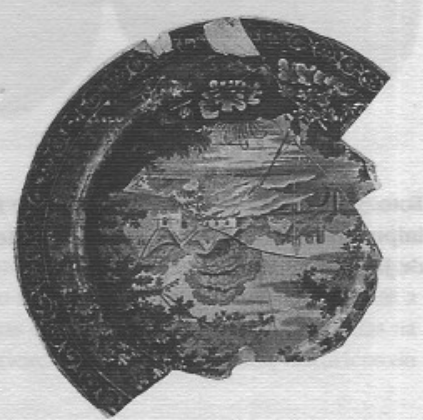

Foto 10: Cena bucólica com borda em volutas (Scroll Border Series), fabricado por Adams, Staffordshire.

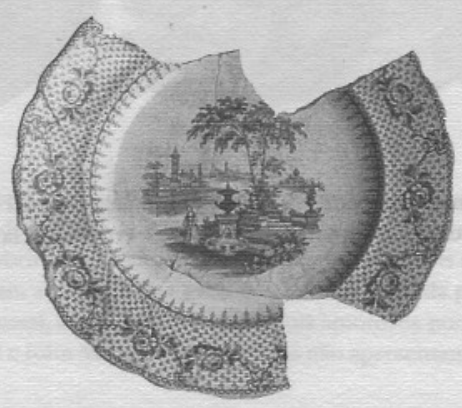

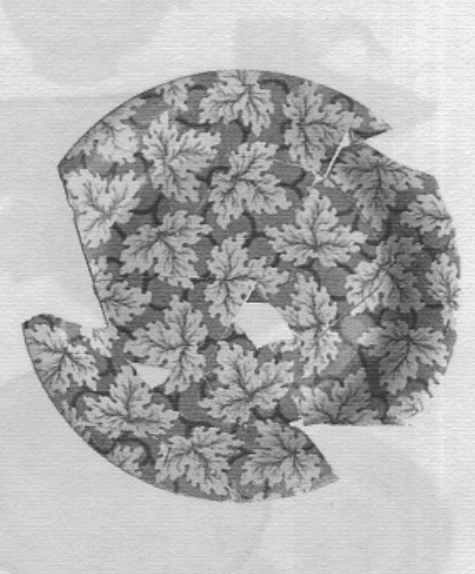

Foto 12: Padrão Sheet, técnica decorativa que, por simplificação e economia, repetia o mesmo motivo em toda superfície da peça, sem borda diferenciada. Muito comum em miniaturas. Proveniência:Sítios históricos do Rio de Janeiro, século XIX. 
Malgas de faiança, destinadas ao consumo de alimentos líquidos e pastosos, sem marcas, em diferentes padrões decorativos.

Foto 13: sponged.

Foto 14: mocha.

Foto 15: cena oriental, em rosa. Foto 16 e 17: pintura a mão em policromia.

Foto 18, 19 e 20: banded, com motivos geométricos. Proveniência: $s i$ tios históricos do Rio de Janeiro, século XIX.

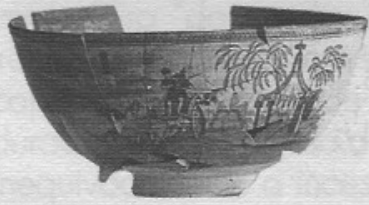

Foto 15

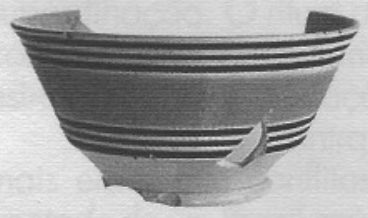

Foto 18

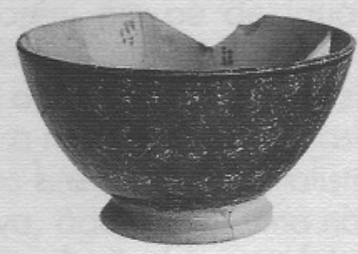

Foto 13

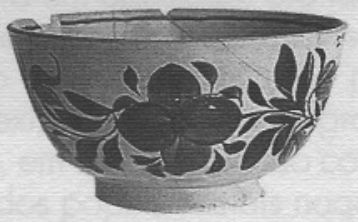

Foto 16

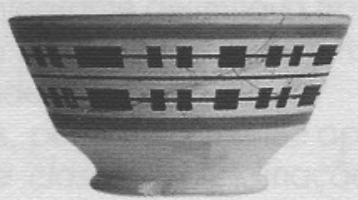

Foto 19

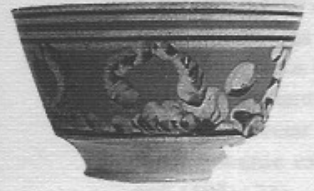

Foto 14

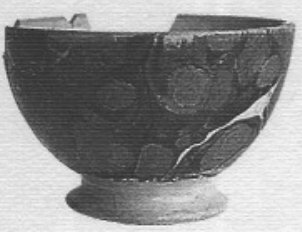

Foto 17

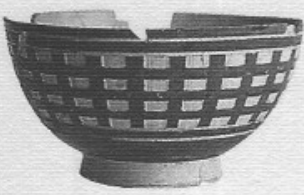

Foto 20 
MUSEUS 
Pratos e mais pratos: louça doméstica, divisões culturais e limites sociais no Rio de Janeiro, século XIX

Tania Andrade Lima

A grande quantidade de louça doméstica que vem sendo recuperada em escavações arqueológicas, realizadas em unidades residenciais do séc.XIX, no Rio de Janeiro, levou a uma reflexão sobre o significado desses objetos para a sociedade que os incorporou tão intensamente ao seu cotidiano. O presente artigo analisa de que modo elas foram utilizadas para a manutenção dos limites, reforçando princípios sociais, e de que modo constituíram uma expressão da ordem então vigente no país.

Unitermos: Louça doméstica. Rio de Janeiro, séc.XIX. Arqueologia histórica

Anais do Museu Paulista, n.sér.,v.3, p.129-191, 1995.

Dishes and more dishes: domestic earthenware, cultural segments, and social limits in 19th-century Rio de Janeiro, Brasil

Tania Andrade Lima

The huge amount of domestic earthenware rescued by current archaeological excavations achieved in habitation sites in 19th-century Rio de Janeiro, asks for a reflection on the meaning of such a kind of artifact for a society that so intensively incorporated it into its everyday life. This article analyzes the ways use was made of earthenware in order to keep on social limits, thus strengthening social principles, and how it became an expression of the prevailing order.

Uniterms: Domestic earthenware. Rio de Janeiro, 19th-century. Historical Archaeology. Anais do Museu Paulista, n.sér, v.3, p.129-191, 1995.

O espetáculo do lpiranga: reflexões preliminares sobre o imaginário da Independência

Cecilia Helena de Salles Oliveira

Este artigo constitui uma incursão inicial em relação ao tema do imaginário da Independência. Toma como questão central a construção de um monumento no lpiranga, celebrativo da data de 7 de Setembro de 1822, e se propõe a discutir tal projeto, conforme foi formulado na década de 1870. Unitermos: Monumento do Ipiranga. Independência do Brasil. Imaginário.

Anais do Museu Paulista, n.sér. v.3, p.195-208, 1995.

The spectacle of Ipiranga: introductory remarks on the 'imaginaire' of Brasil's Independence

Cecilia Helena de Salles Oliveira

This article is a first approach on the 'imaginaire' of Brasil's Independence and deals with the project of a monument intended to celebrate the place where it was declared /the lpiranga fields in São Paulol and the date (September 8,1822 ). The discussion focus on the construction project put forward in the seventies of last century.

Uniterms: Ipiranga Monument. Brasil's Independence. History of the 'imaginaire'.

Anais do Museu Paulista, n.sér. v.3, p.195-208, 1995

A conformação dos ecomuseus: elementos para compreensão e análise

Heloisa Barbuy

Apresenta uma história dos ecomuseus enraizada nos movimentos de folclore e ennografia regional, do final do século XIX até os dias de hoje, examinando o caso francês. Explora aspectos em geral menos enfatizados neste campo, tal como a natureza e o papel atribuído aos acervos e ao patrimônio cultural e padrões museográficos.

Unitermos: Ecomuseu. História do ecomuseu. Museologia. Museografia. Museu de Folclore.

Anais do Museu Paulista, n.sér. v.3, p. 209-236, 1995. 